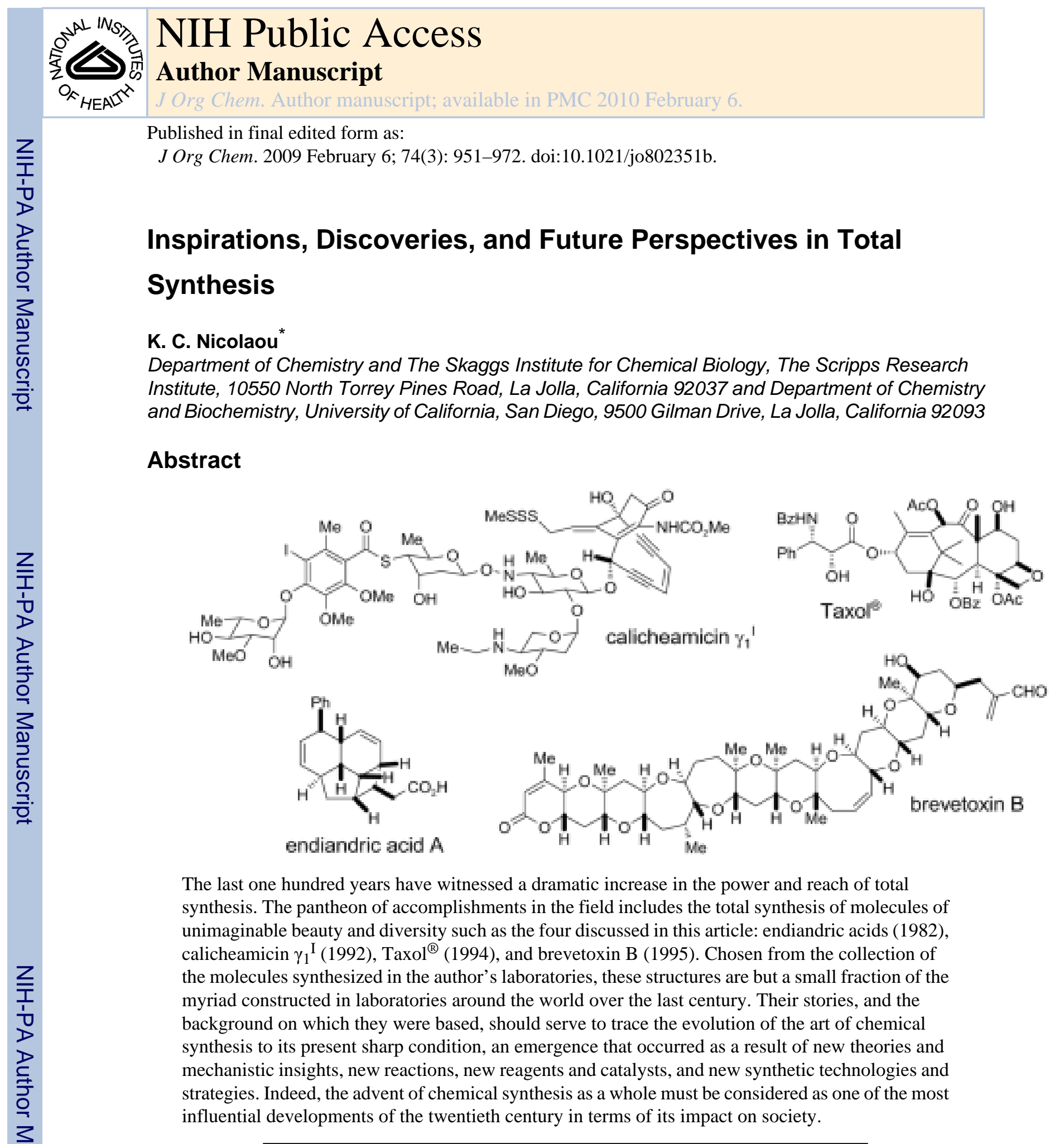

\title{
Introduction
}

I feel privileged to have been asked to participate in the symposium at the $236^{\text {th }}$ ACS National Meeting in Philadelphia on August $18^{\text {th }}, 2008$, celebrating the centennial anniversary of the Organic Division of the American Chemical Society, and for the opportunity to summarize my lecture and my experiences in this invited Perspective. That I was chosen to be one of those

E-mail: kcn@scripps.edu. 
representing organic chemistry, in general, and the field of total synthesis, in particular, is a special honor, for it is within this field that some of the greatest accomplishments of organic chemistry over the last century can be found. ${ }^{1,2}$ And to be given the opportunity to articulate some of the accomplishments of my students and point out the inspirations we received from certain pioneers of the field is particularly gratifying. The wide choice of topics made it difficult, but in the end I chose the endiandric acids (1982), calicheamicin $\gamma_{1}{ }^{\mathrm{I}}{ }(1992)$,

Taxol $^{\circledR}$ (1994), and brevetoxin B (1995) as the molecules to discuss, based on the inspiration provided and the impact of the work on subsequent research activities.

\section{Endiandric Acids}

In 1980, a paper by David St. C. Black and Bryan M. Gatehouse et al. ${ }^{3}$ appeared in J. Chem. Soc., Chem. Commun. disclosing the structure of endiandric acid A (Figure 1), a novel natural product isolated from Endiandra introrsa, a tree endemic to Australia. This disclosure was followed by a second paper from St. C. Black et al. ${ }^{4}$ a few months later in the same journal, in which the authors reported three new members of the endiandric acid family [endiandric acids B and C (isolated, Figure 1), and D (predicted, Figure 1)] of compounds and, most importantly, a brilliant hypothesis for the biosynthetic origins of endiandric acids A-D (Figure 2). The Black biosynthetic hypothesis was a truly inspirational stimulus to my students and me, for it not only pointed the way for a possible laboratory synthesis of these intriguing molecules, but also provided us with the opportunity to build upon past discoveries and theories in order to advance and improve the art of total synthesis in general.

This opportunity arose early in my career, when I had the good fortune to be surrounded by exceptional colleagues at the University of Pennsylvania. Among them was Madeleine M. Joullié, whose support and encouragement I wish to acknowledge. Indeed, over her long career, Joullié, in addition to her magnificent discoveries, has contributed enormously to chemical education through the mentorship and inspiration that she provided to young students and junior faculty. I was one of the lucky beneficiaries of her warm and enthusiastic nurturing that continues to inspire me today. Indeed, Madeleine became a dear and close friend not only to me, but also to my entire family. Another influential figure in my early years at Penn was Michael P. Cava, who was also a good friend of my University College London mentor Franz Sondheimer. Together, Madeleine and Mike ensured my future in chemistry as an independent investigator.

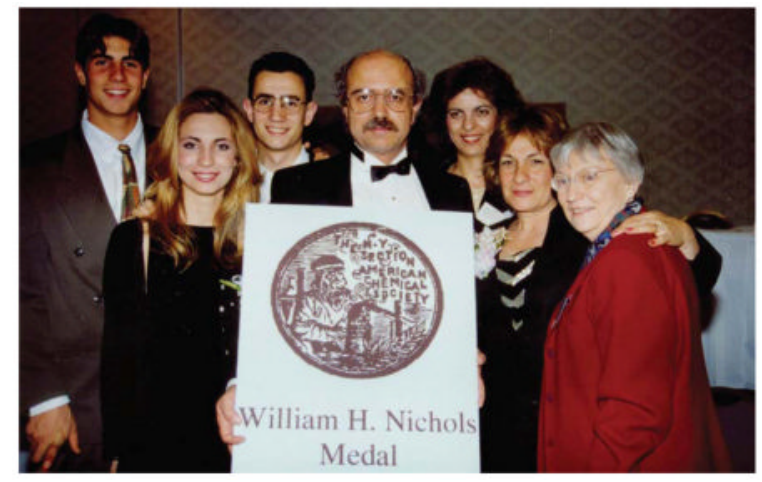

At the William H. Nichols Medal Symposium in New York in 1996 with my family and Madeleine M. Joullié. 


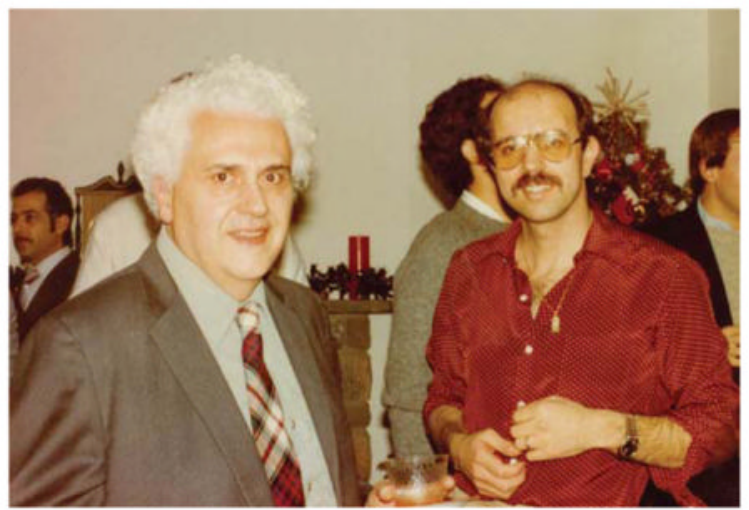

Michael P. Cava (left) and me at a Christmas holiday party at my house in the late 1970s when I was an Assistant Professor at the University of Pennsylvania.

Based on three consecutive electrocyclization reactions, Black's hypothesis postulated acyclic, polyunsaturated fatty acid chains as precursors to the polycyclic frameworks of the endiandric acids as shown in Figure 2. Specifically, it was suggested that the linear precursors would undergo a non-enzymatic $8 \pi e$ electrocyclization to afford cyclooctatriene systems which, in turn, would enter into a $6 \pi e$ electrocyclization to form bicyclic systems, whose intramolecular [4+2] cycloaddition reactions would lead to endiandric acids A-C (leaving behind endiandric acid $\mathrm{D}$, which is unable to react further due to the lack of a dienophile). All three reactions are allowed thermally by the Woodward-Hoffmann rules. Furthermore, all three had been demonstrated previously in the laboratory to be concerted reactions with exquisite stereospecificity, the first two in combination scarcely, ${ }^{5}$ and the third on multiple occasions ${ }^{6}$ since its discovery by Diels and Alder. ${ }^{7}$ Otto Diels and Kurt Alder received the Nobel Prize in Chemistry in 1952 (see Table 1). What made this biosynthetic hypothesis most intriguing, however, was its cascade nature, an aesthetically appealing feature reminiscent of two previously reported and highly inspirational synthetic strategies toward two distinctly different natural products. The first one was Sir Robert Robinson's biomimetic total synthesis of tropinone ${ }^{8}$ from succinic dialdehyde, methyl amine, and acetone dicarboxylate (Figure 3), an accomplishment that has withstood the test of time as a classic since its disclosure in 1917. The second was William S. Johnson's biomimetic total synthesis of progesterone ${ }^{9}$ from a monocyclic precursor through an acid catalyzed cascade sequence (Figure 4) published in 1971, an equally impressive classic in the annals of the art of total synthesis,. This stereoselective synthesis provided verification of the Stork-Eschenmoser hypothesis, first proposed in $1955,{ }^{10}$ for the stereospecific cyclization of a polyunsaturated precursor possessing trans olefinic bonds to a polycyclic system with trans, anti, trans fusion stereochemistry. The gauntlet thrown by the endiandric acids and the opportunities they created were too tempting to resist. Could we reduce to practice in the laboratory the Black biosynthetic hypothesis? Could we apply the rare and exotic $8 \pi e$ and $6 \pi e$ electrocyclizations in the synthesis of complex molecules? And finally, could we champion and promote further the theme of cascade reactions in total synthesis so elegantly demonstrated by Robinson and Johnson?

Our investigations proved pleasant and rewarding. Thus, two strategies were developed toward the endiandric acids, one involving a stepwise and selective construction of the rings of the target molecules (Figure 5), ${ }^{11}$ and the other employing a direct cascade sequence in which all rings and all possible molecules were constructed simultaneously and in one pot (Figure 6). 12 This chemistry not only confirmed the aesthetically pleasing endiandric acid cascade and rendered these molecules readily available through laboratory synthesis, but also delivered a number of endiandric acids unknown at the time, although predicted and later confirmed to be naturally occurring. ${ }^{13}$ Furthermore, this study demonstrated the power of electrocyclizations 
in total synthesis and became the forerunner for things to come, including three total syntheses of the related natural products SNF4435 C and SNF4435 D (Parker and Lim, 2004; ${ }^{14}$ Baldwin et al., 2005; ${ }^{15}$ Beaudry and Trauner, 2005 ${ }^{16}$ ) that proceeded through a conjugated tetraene as shown in Figure 7.

But perhaps the most significant and lasting result of these investigations was the impact they had on future directions in our research. Indeed, both the beauty and the practicality of cascade reactions made a strong impression on my students and me. We continued to design and pursue such cascades in total synthesis throughout the years with rewarding results (e.g. bisorbicillinoids ${ }^{17} \mathrm{CP}-263,114$ and CP-225,917, ${ }^{18}$ colombiasin A, ${ }^{19}$ hybocarpone ${ }^{20}$ diazonamide $\mathrm{A}, 21$ 1- $O$-methyllateriflorone, ${ }^{22}$ thiostrepton, 23 azaspiracids $1-3,24$ bisanthraquinones, ${ }^{25}$ biyouyanagin, 26 and artochamins ${ }^{27}$ ). Pleasantly, we also witnessed the theme of cascade reactions blossom in many other laboratories around the world, reaching an impressive state of prominence as a potent and greener approach to complex molecule construction. ${ }^{28}$ To be sure, we are grateful to Sir Robert Robinson and W. S. Johnson for their pioneering and inspirational examples that encouraged us to add our contributions to the field, beginning with the endiandric acid cascade, which provided the spark for further developments to occur. Robinson won the 1947 Nobel Prize in Chemistry (see Table 1).

Incidentally, David St. C. Black, who proposed the endiandric acid biosynthetic hypothesis, was the first postdoctoral fellow of my postdoctoral mentor, Thomas J. Katz. Katz had worked with R. B. Woodward as a graduate student at Harvard University where the WoodwardHoffmann rules were formulated. The chemistry world might be small, but certainly its impact and inspiration reach far. The Woodward-Hoffmann rules is one of the most significant developments in organic chemistry in the twentieth century. They emerged as a result of the contributions of many and were forged in their general form during, and as a result of, observations made in the collaborative campaign to synthesize vitamin $\mathrm{B}_{12}$ (see Figure 8 for structure) by the Woodward and Eschenmoser groups. ${ }^{29}$ The accomplishment certainly remains as one of the most spectacular and celebrated milestones in the development of the art of total synthesis in the last century. With their impressive achievements, both Woodward and Eschenmoser are rightfully considered giants in the field that they helped shape and in which they dominated so decisively in their eras. Woodward received the 1965 Nobel Prize in Chemistry in (see Table 1). Roald Hoffmann and Kenichi Fukui shared the 1981 Nobel Prize in Chemistry (see Table 1). Albert Eschenmoser, whom I first met in the late 1980s, later became my colleague at The Scripps Research Institute, where I continue to have the pleasure of his brilliant company during his frequent visits to La Jolla. Indeed, I consider myself privileged to be able to enjoy his friendship and council both on scientific and social matters, for which I am grateful. 


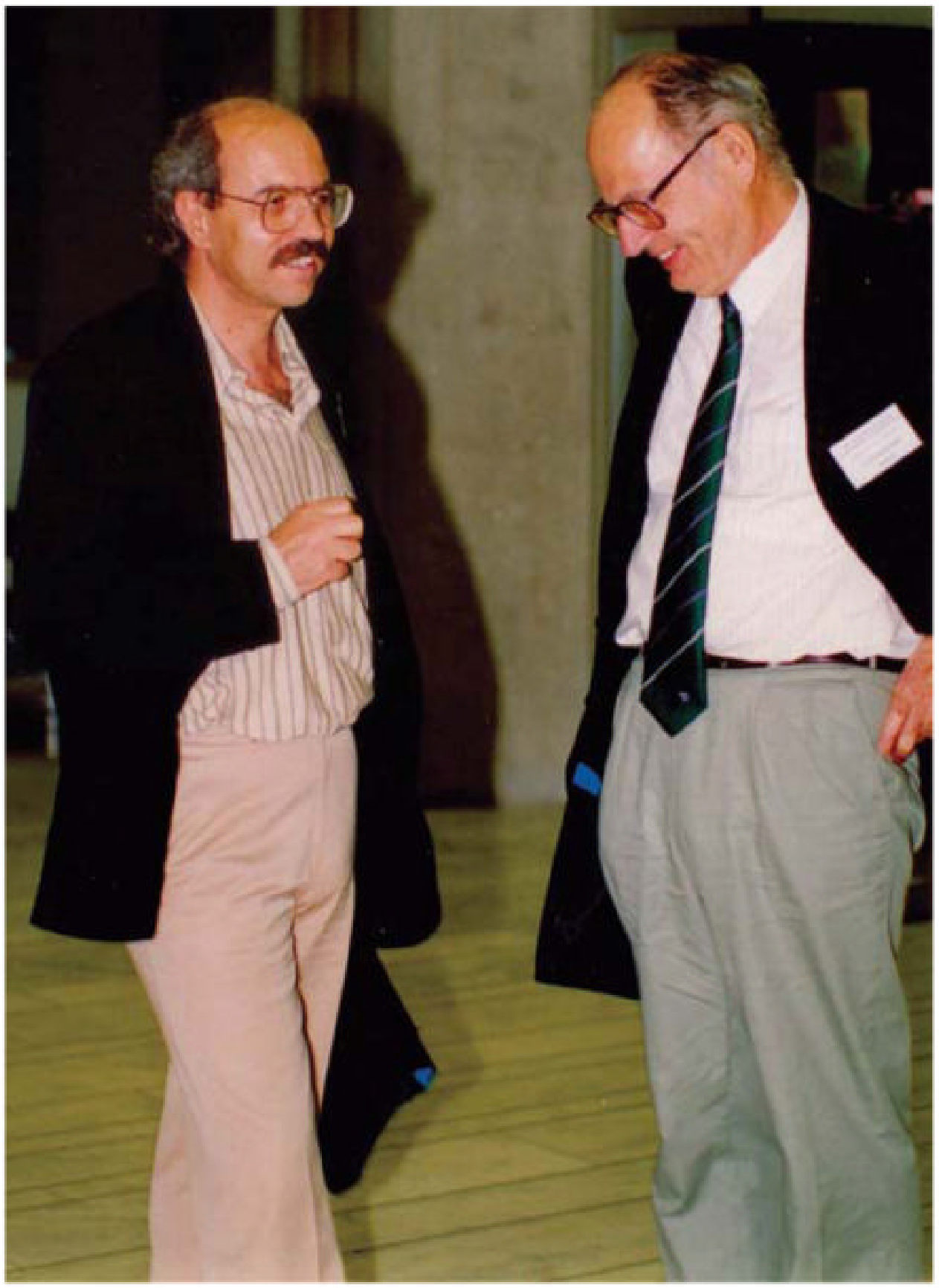

With Albert Eschenmoser (right) at a conference in 1990.

An earlier accomplishment related to the vitamin $B_{12}$ triumph that represents another milestone in the art is the total synthesis of haemin, ${ }^{30}$ the red pigment of blood, in 1929 by Hans Fischer, who was awarded the Nobel Prize in Chemistry in 1930 (see Table 1).

\section{Calicheamicin $\mathbf{Y}_{1}{ }^{1}$}

In July 1986, at a Gordon Conference on Natural Products, Dr. Robert Babine, then at Lederle Laboratories (now Wyeth), alerted me to a new natural product with an "amazing structure and phenomenal biological activity". In September of the same year, during a visit to Lederle 
Laboratories in Pearl River, New York, the structure of calicheamicin $\gamma_{1} \mathrm{I}$ (Figure 9a) was revealed to me, under confidentiality at the time, albeit with two structural errors: one pertaining to the configuration of the aglycon stereocenter carrying the oligosaccharide domain and the other to a point of a sugar attachment onto another. Be that as it may, the molecule was truly amazing and inspirational. By the summer of 1987, the correct structure of calicheamicin $\gamma_{1}$ I (Figure 9b) was in the public domain, ${ }^{31}$ and our first grant application to the National Institutes of Health (NIH) (U.S.A.) had been turned down. Our predicament was double-edged. Not only had we lost our privileged position of being the only group outside the company knowing the structure of calicheamicin $\gamma_{1}{ }^{\mathrm{I}}$, whose bewildering mechanism of action and striking biological activity against the genetic material and tumor cells heightened the intrigue surrounding its stunning molecular architecture, but also we had no funding to compete in what was to become a fierce battle for its conquest by total synthesis. The lure of the molecule was simply too much to ignore, however, and the temporary setbacks were quickly overcome as ways and means were found to continue the campaign that had already started in our laboratories at Penn. Although the central theme of this endeavor was the total synthesis of calicheamicin $\gamma_{1}{ }_{1}$, intertwined tightly with it were aspects of new synthetic technologies, molecular design, and chemical biology. All programs came to fruition, and the rich bounty continues to grow to this day. Before any description of our work, I first wish to pay homage to those who inspired us with the molecule and beyond the molecule, and they were many.

Isolated at Lederle Laboratories by a team led by May D. Lee and George Ellestad from Micromonospora echinospora ssp. calichensis, calicheamicin $\gamma_{1}{ }^{\mathrm{I}}$ was named after its producing organism's habitat, caliche (the Greek word for limestone pebble), which was collected by a touring scientist from the side of a highway in Texas. Its stunning molecular architecture prominently displays a ten-membered enediyne ring which is amazingly stable until it is perturbed through an intramolecular Michael addition of an in situ generated sulfur nucleophile to an $\alpha, \beta$-unsaturated enone moiety that apparently holds the key to the molecule's stability. This internal reorganization of the structure of the molecule signals a Bergman cycloaromatization, a thermally induced reaction first designed and reported by Robert Bergman in 1972,32 then at the California Institute of Technology (Figure 10). The Bergman reaction, which had also been observed by Masamune et al. ${ }^{33}$ and Wong and Sondheimer ${ }^{34}$ prior to the discovery of calicheamicin $\gamma_{1}{ }^{\mathrm{I}}$, lies at the heart of the mechanism of action of this enediyne natural product (Figure 12). These pioneering studies must have been as instrumental to the structural elucidation of calicheamicin $\gamma_{1}{ }^{\mathrm{I}}$ (Figure 9) and the determination of its mechanism of action (Figure 11) as they were inspirational to us as we embarked on the total synthesis of this molecule and the study of its enediyne structural motifs. Indeed, these conjugated systems brought back memories from my Ph.D. studies at University College London with Peter J. Garratt and Franz Sondheimer, where I learned much about acetylenes and cyclic conjugated systems; and I simply could not stay out of what I knew would become a fierce battle for the molecule.

As the father of annulene chemistry, Franz Sondheimer not only provided experimental confirmation of the Hückel rule of aromaticity, but most importantly, he stimulated the advancement of the field of aromaticity and theoretically interesting molecules far beyond its traditional boundaries. He left a legacy that preceded the enediyne natural products and the fullerenes. Having been exposed to conjugated systems, particularly cyclic allenes and acetylenes, during my Ph.D. studies in the Sondheimer-Garratt camp, I formed a natural affection for, and strong interest in, the enediyne natural products immediately upon my first encounter with the molecule of calicheamicin $\gamma_{1} \mathrm{I}$. And so it was that I fully committed myself and my team to the calicheamicin $\gamma_{1}{ }^{\mathrm{I}}$ campaign, not certain of its outcome. To be sure, though, I knew that the journey would be full of excitement and riches in discoveries and adventures, both in chemistry and biology; and, so it was. 


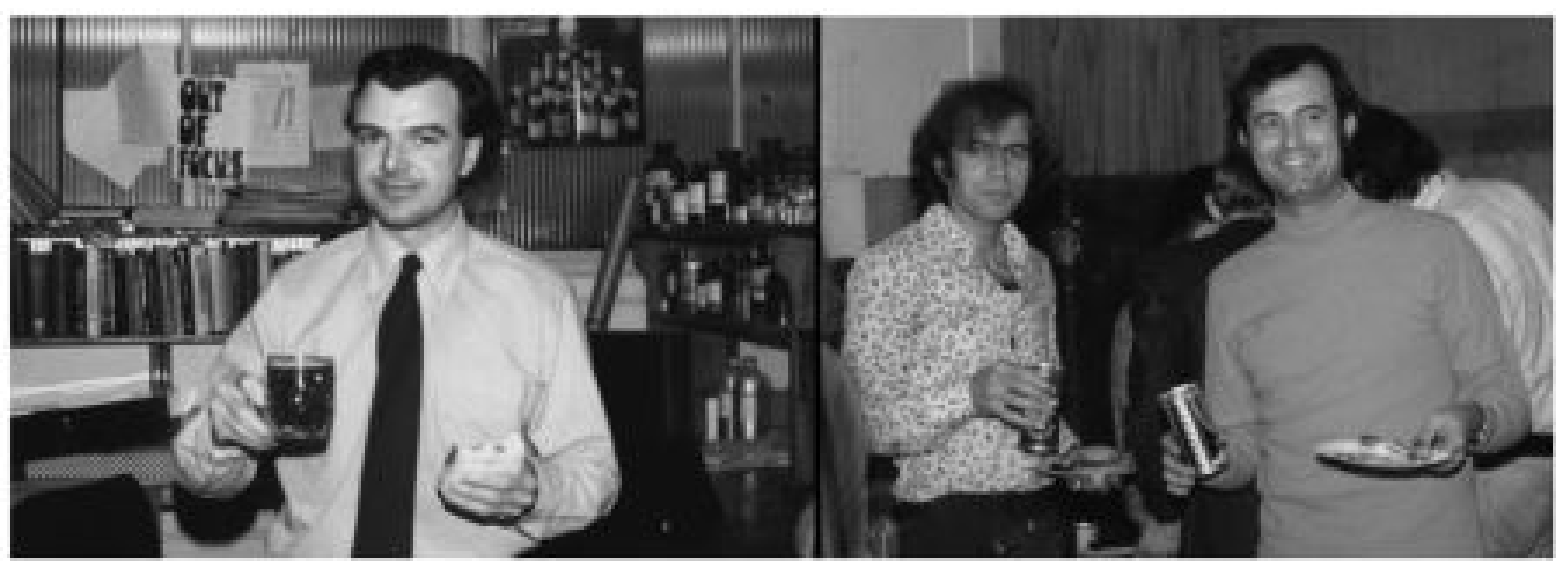

Peter Garratt (left, my Ph.D. mentor), me (center), and Dimitrios Nicolaides (right, from the University of Thessaloniki, Greece) at University College London in the early 1970s. In addition to the total synthesis of calicheamicin $\gamma_{1}$ ( (Figure 12), 35 a number of other notable discoveries were made during this campaign. Thus, a general method was developed based on the Ramberg-Bäcklund reaction for the synthesis of cyclic enediynes, ${ }^{36}$ many of which were made and studied (Figure 13). Among them was the first designed enediyne to exhibit double strand cleavage of duplex DNA through a thermal reaction and in the absence of any additives or co-factors (Figure 14). We also had the opportunity to design and synthesize the first analogs of another naturally occurring enediyne antitumor antibiotic, dynemicin A (Figure 15). ${ }^{37}$

These designed enediynes exhibited interesting biological properties, including DNA cleaving properties and potent cytotoxicities against a variety of tumor cells (e.g. PM-9, Figure 15). ${ }^{37}$ These studies also led us to the discovery of cyclic and acyclic propargylic and allenic sulfones (Figure 16) as DNA cleaving agents endowed with cytotoxic properties. ${ }^{38}$ It was gratifying to see the influence of these discoveries were, as evidenced by several reports from around the world. 39

During the same campaign, we also had the opportunity to synthesize a number of complex oligosaccharides patterned after the calicheamicin $\gamma_{1}{ }^{\mathrm{I}}$ oligosaccharide domain and study their interactions with duplex DNA fragments, leading to some interesting insights into carbohydrate-DNA recognition. ${ }^{40}$ Also quite interesting was the observation, by X-ray crystallography, of two forms of crystals of the fully substituted aromatic moiety of calicheamicin $\gamma_{1}$ I (Figure 17), each containing enantiomeric molecules of unusual shapes $[(R, R, R$,$) and (S, S, S)] .41$

In 1994, Samuel J. Danishefsky and his team published their elegant total synthesis of calicheamicin $\gamma_{1}{ }^{\mathrm{I}}{ }^{42}$ Over the last few decades, the Danishefsky group has demonstrated their flair and acumen in total synthesis with numerous examples of complex natural products in which they made important contributions to new synthetic methodology and chemical biology.

Following our studies on calicheamicin $\gamma_{1} \mathrm{I}$ and other enediynes in the late 1980s and early 1990 s, it was gratifying to watch the field blossom with new structures being isolated from nature ${ }^{43}$ and synthesized in the laboratory. ${ }^{44-51}$ Furthermore, many designed enediynes have been synthesized and studied. ${ }^{39 \mathrm{c}}$ With the recent discovery of uncialamycin (Figure 18), ${ }^{43 \mathrm{~d}}$ it seems that nature has not yet finished revealing its last enediyne antitumor antibiotic, offering the synthetic chemist further inspiration and expectation for yet more challenges to come. This latest challenge was met by us recently, first with a total synthesis of racemic uncialamycin 52 that defined the complete relative stereochemistry of the molecule, and then with an enantioselective total synthesis of the natural product ${ }^{53}$ that elucidated its absolute 
stereochemistry and rendered it, and its $26(S)$ isomer, readily available for biological studies. These investigations revealed uncialamycin's full spectrum of biological action against duplex DNA (Figure 19) and several bacterial strains and tumor cells, including drug resistant lines, and underscored, once again, the importance of chemical synthesis in rendering scarce but valuable naturally occurring substances for biological investigations.

\section{Taxol $^{\circledR}$}

As important as it was at the time, the 1971 paper in the Journal of the American Chemical Society by Mansukh E. Wani and Monroe C. Wall et al. ${ }^{54}$ reporting the isolation of Taxol ${ }^{\circledR}$ (Figure 20) from the Pacific Yew tree (Taxus brevifolia) did little to predict the celebrity status and enormous impact this molecule would have on chemistry, biology, and medicine in the years to come. At the time, the molecule looked almost impossible to synthesize by virtue of its densely functionalized and crowded nature, and its natural abundance was prohibitively low for a potential drug. Its severe insolubility in aqueous media and unknown mechanism of action were additional and sufficient reasons for its lingering on the shelves of the National Cancer Institute (NCI) (U.S.A.), but a number of events would propel it to the front page and on center stage. In 1979, Susan Horwitz and coworkers discovered the then new but now familiar tubulin polymerization/microtubule stabilization mechanism of action of Taxol ${ }^{\circledR} .55$ This discovery heightened the interest in the molecule as a potential drug candidate for cancer chemotherapy, and, by 1992, Taxol ${ }^{\circledR}$ was approved by the Food and Drug Administration (FDA) in the United States as an anticancer drug, despite the low supplies provided through sacrificing unsustainably large numbers of Pacific Yews. 56 Realizing the importance of the molecule, synthetic chemists embarked on the ambitious goal of synthesizing Taxol ${ }^{\circledR}$ in the laboratory, beginning from the late 1970 s.

While the inspiration to embark on the ambitious adventure of the total synthesis of Taxol ${ }^{\circledR}$ came from nature through the brilliant chemical detective work of Wani and Wall, who isolated and elucidated its structure, the courage to enter into the campaign was the result of Professor E. J. Corey's mentorship, in whose Harvard laboratories I was a postdoctoral fellow (19731976). He taught me to delve into the unknown and to continue to learn in the process of exploring through patience and logic. Indeed, through this rather simple, but wise and highly effective philosophy, and with discipline, he impacted enormously the field of organic chemistry, from theory to total synthesis, from mechanism to new reactions, and from new reagents and catalysts to asymmetric synthesis. Through his influential contributions to science and education, he helped shape the field of chemical synthesis perhaps more than any other individual in the last century, providing the foundation for developments in chemical biology and pharmaceutical research. Corey received the Nobel Prize in Chemistry in 1990 (see Table 1).

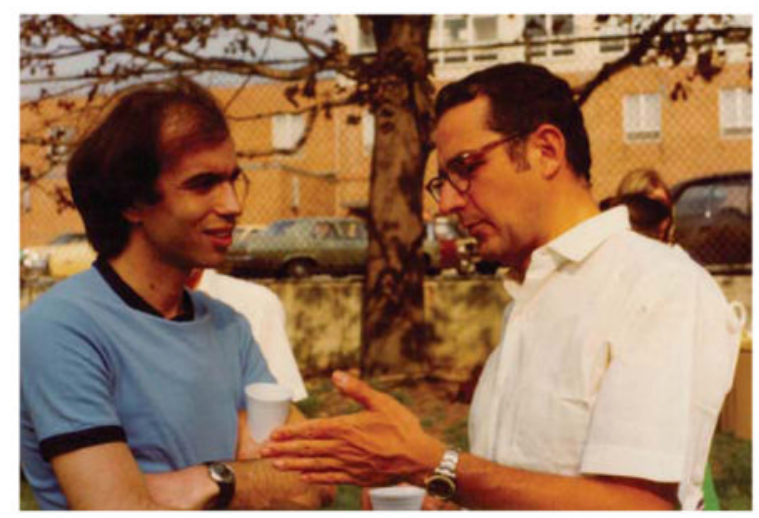


E. J. Corey making a point to me at a group picnic at Harvard in 1974.

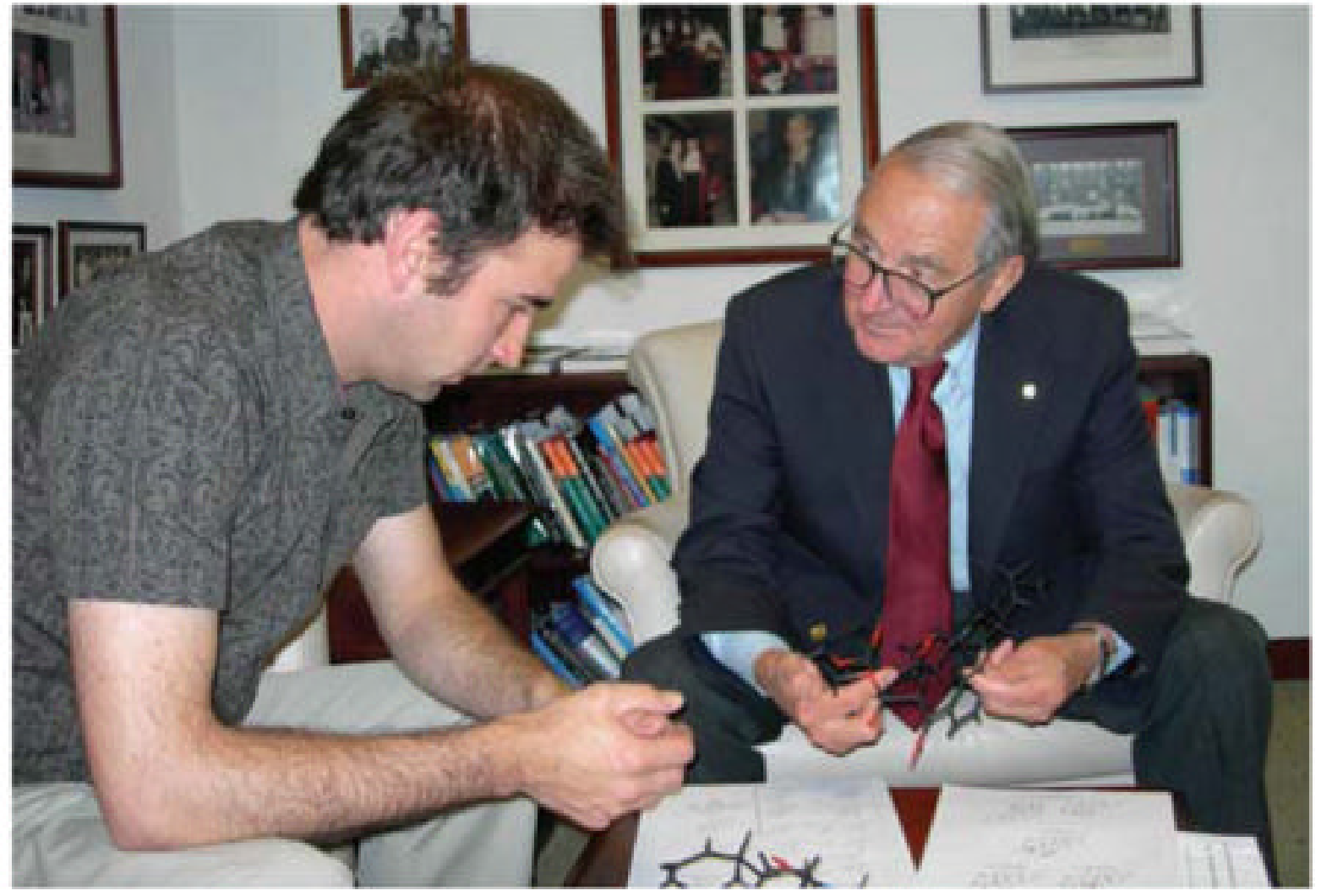

E. J. Corey in my office making a point to one of my students (David Sarlah) during a visit to Scripps in 2008.

One of Corey's most brilliant accomplishments in total synthesis is the total synthesis of ginkgolide B (see Figure 21 for structure). ${ }^{57}$ Published in 1988, this beautiful synthesis impressed me deeply, for it made me realize that even seemingly impossible molecules could be made in the laboratory with systematic experimental exploration of carefully planned synthetic pathways that may include new reactions. Inspired by the complexity of Taxol ${ }^{\circledR}$ and its similarity to ginkgolide $\mathrm{B}$ (highly rigid and strained, they are both polycyclic $\mathrm{C}_{20}$ diterpenes, densely functionalized with oxygen atoms), and the acute need to find a laboratory synthesis of the molecule, we entered the scene in 1991 with a simple, but bold and risky, plan characterized by high convergency and overall brevity. Figure 22 summarizes the overall endeavor as first published in $1994 .{ }^{58}$ Diels and Alder $^{7}$ must be credited for their reaction in this total synthesis, for it provided the means to cast both rings A and C of the molecule. Koichi Narasaka ${ }^{59}$ deserves the credit for the boron tethering technique that forced the desired regiochemistry of the $\mathrm{C}$ ring yielding Diels-Alder process. Robert H. Shapiro ${ }^{60}$ and John E. McMurry ${ }^{61}$ deserve credit for their namesake reactions that were employed to assemble the two fragments into the tricyclic framework of the target molecule, and Robert A. Holton 62 and Iwao Ojima ${ }^{63}$ should be praised for pioneering the attachment of the side chain as the molecule of Taxol ${ }^{\circledR}$ grew to its full size and shape. The lion's share of credit, however, should go to my students who made it happen in such a timely and rewarding manner.

The lasting impact of the total synthesis of Taxol ${ }^{\circledR}$, as evidenced by the many citations it received, stems from the fact that it served as the quintessential symbol of the power of chemical synthesis as it stood at the time. The several new synthetic technologies and strategies developed and the many Taxol ${ }^{\circledR}$ analogs designed, synthesized, and biologically 
evaluated 64 added considerable breadth to the impact of the work. Indeed, the multifaceted nature of the Taxol ${ }^{\circledR}$ project allowed us to make noteworthy contributions to both chemical synthesis and chemical biology through the novel taxoid molecules that we were able to design and synthesize, some of which are shown in Figure 23.

At about the same time as our disclosure in 1994, the Holton group reported their elegant total synthesis of Taxol ${ }^{\circledR}{ }^{65}$ Subsequently, the groups of Danishefsky, ${ }^{66}$ Wender, ${ }^{67}$ Mukaiyama, 68 and Kuwajima ${ }^{69}$ reported their admirable total syntheses of Taxol ${ }^{\circledR}$. All of these campaigns contributed significantly to the art of total synthesis and beyond.

\section{Brevetoxins}

In 1981, Koji Nakanishi and Jon C. Clardy reported in the Journal of the American Chemical Society the structure of brevetoxin B (Figure 24), ${ }^{70}$ a magnificent molecule whose catastrophic effects on marine life and its extended ecosystem may have been noticed by humans as early as the times of Moses. Indeed, as one of the main neurotoxins associated with the red tides, brevetoxin B is partly responsible for massive fish kills, the deaths of dolphins and whales, and the notorious neurotoxic shellfish poisoning (NSP) that inflicts humans. ${ }^{71}$ Its sibling, brevetoxin A, reported from the laboratories of Yuzuru Shimizu and Clardy in 1986, ${ }^{72}$ is even more potent and just as impressive architecturally. Brevetoxin B being the first member of the ladder-like polyether marine biotoxins, a family of natural products now numbering more than 50 , commands a special place in the annals of natural products chemistry. Its fused polycyclic structure boasts 11 consecutive rings, each with an oxygen atom in a pseudo-regular arrangement in which every two adjacent oxygens are separated by a carbon-carbon bond and 23 stereogenic centers. The molecule terminates with an $\alpha \beta$-unsaturated aldehyde at one end and an $\alpha \beta$-unsaturated $\delta$-lactone at the other, and carries on its polycyclic framework one hydroxyl and seven methyl groups. All in all, brevetoxin B presented, back in 1981, a formidable and unprecedented synthetic challenge. Its stunning molecular structure inspired awe, admiration, and, to be sure, apprehension over any attempt to construct it in the laboratory due to the lack of suitable methods to form its structural motifs, fused cyclic ethers of varied sizes, and strict stereochemical requirements.

The ladder-like marine polyether biotoxins are reminiscent of the artificial crown ethers and related compounds that revolutionized molecular recognition and led to the emergence of the field of supramolecular chemistry. Jean-Marie Lehn, Donald Cram, and Charles Pedersen shared the Nobel Prize in Chemistry in 1987 for establishing this field of investigation (see Table 1). Relying on molecular design and chemical synthesis, this area continues to grow and expand in new directions such as molecular devices and nanotechnology.

At this juncture, a tribute to those practicing the tedious and arduous task of isolation and structural elucidation of natural products is appropriate, for their important contributions provide invaluable inspiration for us practitioners of the art of total synthesis. In addition to those already mentioned above, there are others, too many to include here. Dorothy Crowfoot Hodgkin, however, merits special mention because of her X-ray structural determinations of a number of legendary molecules that have influenced the development of total synthesis. These molecules include penicillin, vitamin $\mathrm{B}_{12}$, thiostrepton, and insulin. For her contributions, Hodgkin received the 1964 Nobel Prize in Chemistry (see Table 1).

And so it was that we started on the road to brevetoxin B, fearing not, but rather looking forward to, the battle with the molecule in the hope of riches of new synthetic technologies and strategies, and perhaps the ultimate prize, synthetic brevetoxin B itself. The brevetoxin B campaign began in 1982 with the recognition that a polyepoxide type molecule may serve as a chemical precursor of brevetoxin B (Figure 25). ${ }^{73}$ However, while the zip type cascade reaction required to produce brevetoxin $B$ from a polyepoxide such as one of those shown in 
Figure 25 may be facilitated within Karenia brevis (the producing dinoflagellate organism) by enzymes, such a reaction in the laboratory was considered unlikely at the time due to the lack of suitable methods to achieve the obligatory stereo- and regioselectivity. This polyepoxide cascade was formalized by Nakanishi et al. in 1985 as a biosynthetic hypothesis, ${ }^{74}$ and partially demonstrated in the laboratory by Jamison and Vilotijevic in $2007 .{ }^{75}$ In order to overcome the natural tendencies to form the wrong size rings, we sought to develop a number of stepwise approaches to cyclic ethers. These methods are briefly summarized as we highlight their applications to the total synthesis of brevetoxin B and its sister molecules, hemibrevetoxin and brevetoxin A.

In our initial foray in 1985, we developed and reported the first regio- and stereoselective hydroxy epoxide openings for the formation of cyclic ethers (Figure 26). ${ }^{76}$ The placement of a carbon-carbon double bond on one side of the epoxide moiety was sufficient to override, by virtue of its stabilization effect on the developing positive charge, the natural tendency of the molecule to undergo the undesired 5-exo cyclization, ${ }^{77}$ leading instead to the desired tetrahydropyran system with inversion of configuration at the point of attack under acid conditions. The substrates for this powerful cyclic ether forming reaction are easily derived in their enantiomerically enriched form from allylic alcohols through the Sharpless asymmetric epoxidation reaction, 78 and the resulting products, equipped with an olefinic bond, are synthetically fertile, facts that made this method practical and quite popular.

At this juncture, a tribute to K. Barry Sharpless is in order, for his invaluable contributions to our field are numerous and influential. Among them, the asymmetric epoxidation of allylic alcohols has had perhaps the most profound impact on our work in total synthesis, as we and many others employed it with success on countless occasions, including the synthesis of the polyether marine biotoxins. Sharpless shared the 2001 Nobel Prize in Chemistry with Ryoji Noyori and W. J. Knowles (see Table 1). In 1990, Sharpless joined The Scripps Research Institute, and together with Chi-Huey Wong, Dale Boger, and me, we became the founding quartet recruited to establish the Department of Chemistry, which was seeded in 1989. I am grateful to all of these pioneers and especially to Barry not only for his inspiration, but also for the support and encouragement that he provided to my students and me over the years.

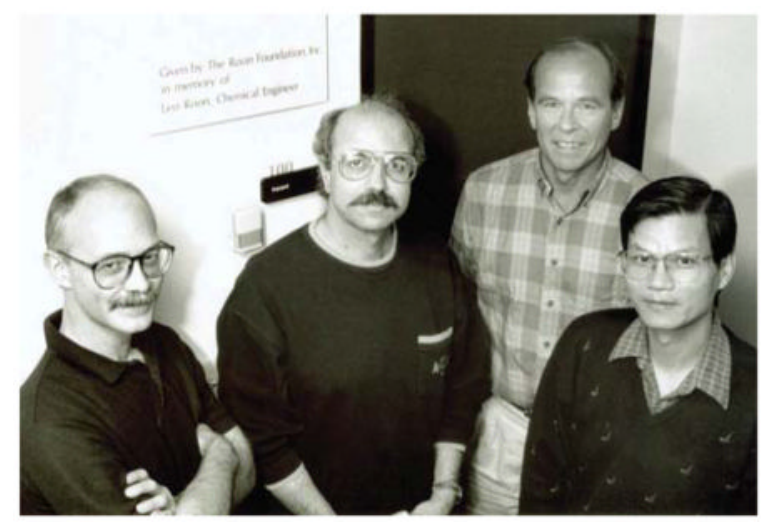

With my colleagues at The Scripps Research Institute in the mid-1990s. Left to right: Dale Boger, myself, K. Barry Sharpless, and Chi-Huey Wong. (Courtesy of The Scripps Research Institute $\left.{ }^{\circledR}\right)$

A second method for the synthesis of cyclic ethers, this time from hydroxy ketones through the intermediacy of mixed $O, S$-ketals, was reported from our laboratories in 1986 (Figure 27). 79 Proceeding through the corresponding hydroxy dithioketals or hydroxy thionium species, this synthetic strategy allows the generation of the hydrogen-substituted (reductive removal of 
the sulfur substituent, e.g. $\mathrm{Ph}_{3} \mathrm{SnH}-\mathrm{AIBN}$ ) or methyl-substituted product (oxidative removal of the sulfur substituent, e.g. $m$-CPBA; $\mathrm{AlMe}_{3}$ ) as shown in Figure 27. This flexibility to install either a hydrogen, or a methyl group adjacent to the ethereal oxygen was a highly welcomed feature of this method since these are the two most common substituents found in those positions of the polyether marine toxins.

Of particular importance in the context of this method is the radical-based chemistry that leads to the desired cyclic ethers through reductive removal of the sulfur residue. While many have made contributions to the field of radicals as transient intermediates for chemical synthesis, the two most prominent pioneers are arguably Sir Derek H. R. Barton and Gilbert Stork. Both merit mention in this article not only for their influential work on radical chemistry, but also because of the inspiration they provided to the rest of us through their multiple contributions to the theory, art, and science of synthesis, both in methodology and total synthesis. Of particular importance is the theory of conformational analysis developed by Sir Derek Barton, for which he shared the 1969 Nobel Prize in Chemistry with Odd Hassel (see Table 1).

My relationship with Sir Derek Barton was fascinating and started in the form of correspondence from the time I was an undergraduate at Bedford College London, when I almost entered his group as a Ph.D. student. Joining the Sondheimer-Garratt group instead at University College London in 1969 (a few days before the announcement of Sir Derek's Nobel Prize!), I returned to him again a few years later with the desire to enter his group as a postdoctoral fellow. However, I failed to secure the obligatory fellowship for the intended position. As an Assistant Professor, I tried hard to impress Sir Derek, but it took a rather long time before he would yield. Eventually, we became close and I enjoyed both his company and advice, and his exquisite wines.

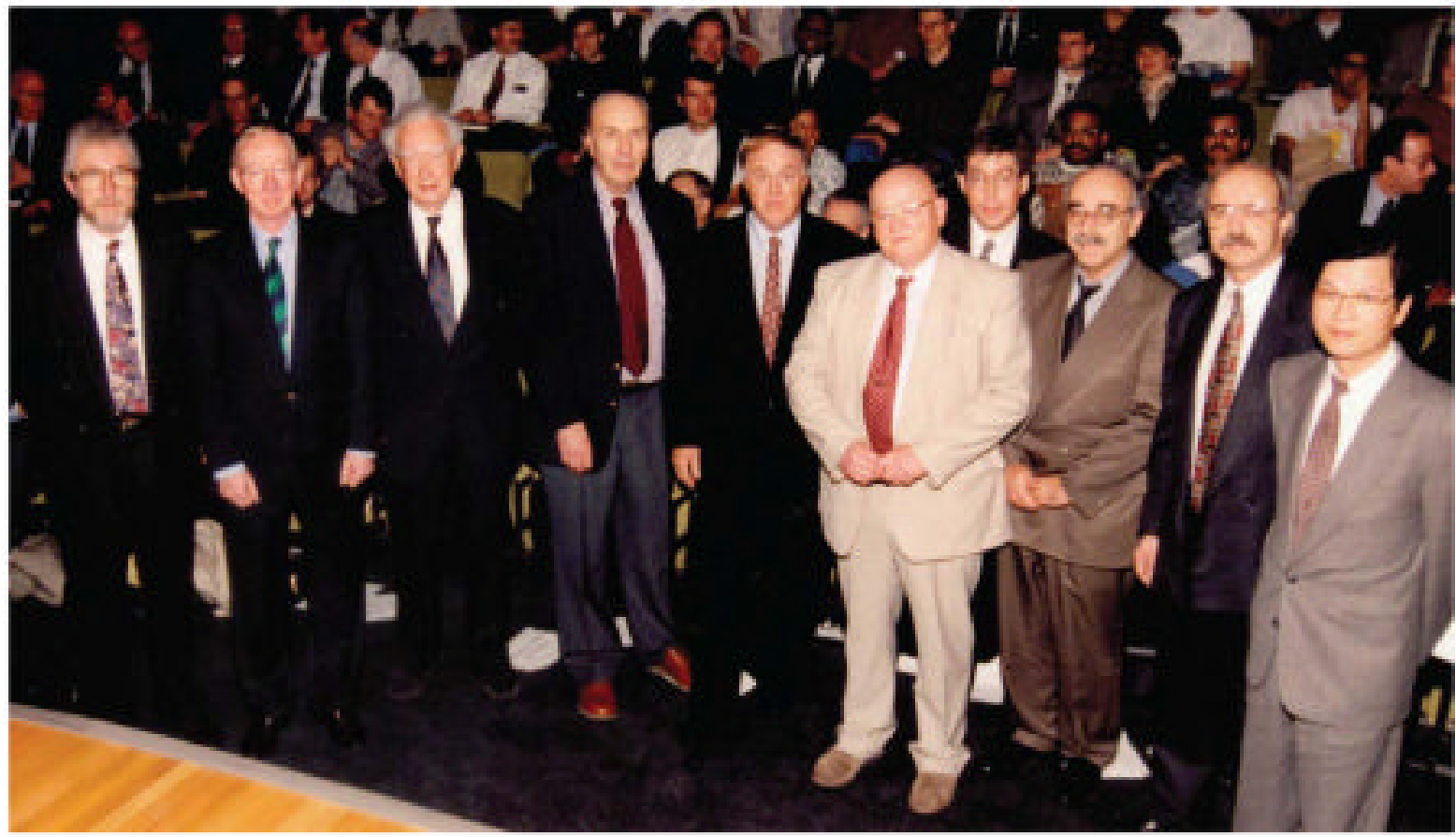

Sir Derek H. R. Barton at a symposium at Scripps on February 6, 1998, celebrating his $80^{\text {th }}$ birthday. Left to right: Philip D. Magnus, Bengt I. Samuelsson, Sir Derek H. R. Barton, A. Ian Scott, Richard A. Lerner, Sir Jack E. Baldwin, Erik J. Sorensen, Julius Rebek, Jr., myself, and Chi-Huey Wong. (Courtesy of The Scripps Research Institute ${ }^{\circledR}$ ) 
We recognized early on the potential of lactones as precursors to the same sized cyclic ethers through suitable manipulation. This led to a number of practical methods for cyclic ether formation, including the aesthetically pleasing bridging of macrocycles to bicycles and the often used Stille and $B$-alkyl Suzuki couplings of vinyl phosphates and triflates. Initial attempts to directly convert lactones to the corresponding cyclic ethers through tetrahedral intermediates failed due to the propensity of the ladder to rupture into open chain systems. These observations led us to thionolactones (prepared from lactones and Lawesson's reagent), for we expected their tetrahedral intermediates to retain cyclic structures due to the stronger ability of sulfur to stabilize a negative charge as compared to oxygen. Indeed, employing thionolactones, we successfully developed several synthetic technologies for the formation of cyclic ethers utilizing electron donors (Figure 28), ${ }^{80}$ photoirradiation (Figure 28), 81 or nucleophilic reagents (Figure 29). 82

Inspired by the pioneering work of George Olah, ${ }^{83}$ we developed, and reported in 1989, a direct method for the formation of cyclic ethers from hydroxy ketones (Figure 30a). ${ }^{81 b}$ This oxepane forming reaction was a forerunner of the tetrahydropyran forming processes reported subsequently from the laboratories of P. A. Evans (Figure 30b) ${ }^{84}$ and Sasaki (Figure 30c).

85 Olah has influenced organic chemistry in many ways; his contributions span from his work on carbocations and new synthetic methods and reagents, to his inspirational leadership and mentorship of young students and faculty. Olah received the 1994 Nobel Prize in Chemistry (see Table 1). I feel fortunate to be able to enjoy his friendship and our frequent encounters, and would like to express my gratitude for his inspiration, encouragement, and support.

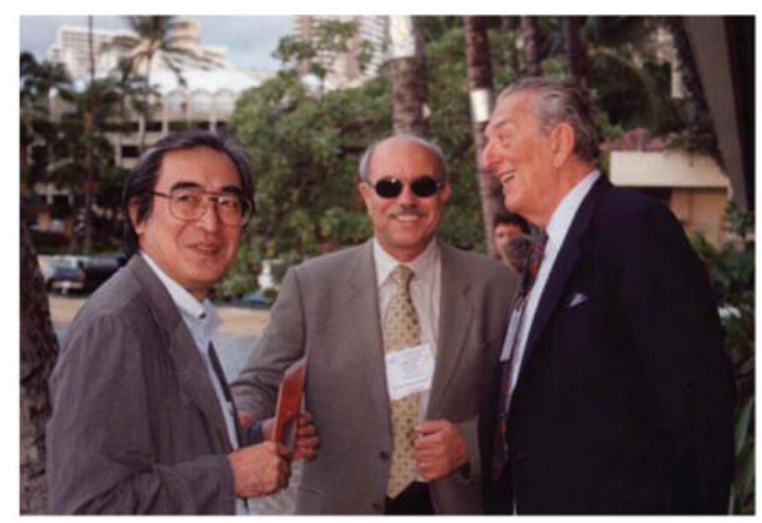

With Masakatsu Shibasaki (left) and George Olah (right) at the Pacifichem meeting in Hawaii in 2005 .

With the advent of the olefin metathesis reaction as a practical proposition in the early 1990s, and inspired by the early work of Grubbs in the field, 86 we proposed a general and highly convergent method for cyclic ether formation that involves ester methylenation and olefin metathesis (Figure 31). ${ }^{87}$ Initially reported from our laboratories in 1996, this method employed the Tebbe reagent ${ }^{88}$ to induce, sequentially and in one pot, both the methylenation and the metathesis reactions, leading directly to the desired products as indicated in Figure 31. This protocol was applied to the construction of several polyethers, including those shown in Figures 32 and 33. Of special interest are the expedient routes developed toward the JKL and UVW maitotoxin domain models based on this method and shown in Figure $33 .{ }^{89}$ Here I take the opportunity to pay homage to Robert Grubbs and the other pioneers of the olefin metathesis reaction, including Nissim Calderon, Yves Chauvin, Thomas J. Katz, and Richard R. Schrock, for their magnificent contributions to the science of chemical synthesis. Indeed, their reaction revolutionized the way we think about synthesis today, whether it is directed toward polymers, designed molecules, or natural products. Grubbs, Chauvin, and Schrock shared the 2005 Nobel 
Prize in Chemistry (see Table 1). Although I have great admiration for the metathesis reaction today and those who refined it, I must confess that as a postdoctoral fellow 32 years earlier in the Katz laboratory, where I witnessed the investigations into its mechanism, I had no idea of how far this reaction would come as a tool for chemical synthesis. Indeed, I did not have much patience then for the tarry mixtures produced by it every day right next to me, where graduate student Jim McGinnis was working on the project. I am grateful to Tom Katz for his inspiration and support over the years. Indeed, it was his generosity and brilliance that assimilated me into the American system and sent me to my next post, at Harvard, as a postdoctoral fellow with E. J. Corey.

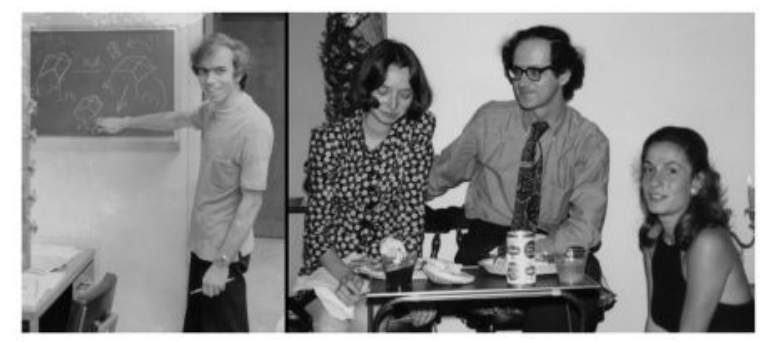

From left to right: Showing off my chemistry on the blackboard next to my desk at Columbia University (the door in the background was Thomas J. Katz's office across the hall), and also Meta and Thomas Katz, and Georgette (my wife) in our apartment in Dumont, New Jersey, where we were living when I was a postdoctoral fellow at Columbia in 1973.

Inspired by the work of Murai et al., 90 we developed a particularly useful method for the construction of cyclic ethers that involves convergent cross couplings of vinyl phosphates or triflates with organometallic species (e.g. cuprates, Nozaki-Hiyama-Kishi, Stille). Particularly useful was the palladium-catalyzed Stille coupling of vinyl phosphates with vinyl stannanes (Figure 34a). ${ }^{91}$ This reaction was later extended by Sasaki et al. ${ }^{92}$ to include the palladiumcatalyzed Suzuki coupling of these intermediates with $B$-alkyl boranes (Figure 34b), and by us to vinyl phosphates of lactams as intermediates for the construction of $N$-heterocycles. ${ }^{93}$ Collectively, these methods have found extensive applications in the total synthesis of polyether marine biotoxins and other cyclic compounds.

Figures 35-37 summarize our total synthesis of brevetoxin B (1995), ${ }^{94}$ highlighting the application of the new synthetic technologies that we developed specifically to solve this synthetic puzzle. It was especially gratifying to watch the extension and application of these methods to numerous other total syntheses of marine biotoxins, including hemibrevetoxin (1992, Figure 38) $)^{95}$ and brevetoxin A (1998, Figures 39-41), ${ }^{96}$ in our laboratories.

Furthermore, and much to our delight, our synthetic technologies and strategies were extended and extensively applied by others in their total synthesis endeavors directed toward the marine biotoxins. $97-110$

This article would not be complete without mentioning the largest secondary metabolite discovered to date. That natural product is the marine polyether biotoxin maitotoxin (Figure 42). Isolated and structurally elucidated by the groups of Yasumoto, ${ }^{111}$ Tachibana, ${ }^{112}$ and Kishi, ${ }^{113}$ maitotoxin also holds the record for the most toxic non-peptidic substance presently known to man. I wish to acknowledge the inspirational role that Yoshi Kishi has played in my career not only through his crucial synthetic work that facilitated the structural elucidation of maitotoxin, but also his Herculean accomplishment of the total synthesis of palytoxin, the largest secondary metabolite to be synthesized in the laboratory thus far. ${ }^{114}$ Kishi has accomplished a number of other impressive total syntheses in his distinguished career. 
The NMR-based structure of maitotoxin was recently questioned by Spencer and Gallimore on the basis of biosynthetic considerations, 115 a challenge to which we responded with synthetic studies. ${ }^{116}$ These studies stimulated the development of additional new synthetic methods for cyclic ether formation in our laboratories, such as the one shown in Figure 43. Based on the Noyori asymmetric reduction, ${ }^{117}$ this method employs furan and its derivatives as starting substrates, and utilizes an Achmatowicz rearrangement as the key step to forge the required six-membered ring systems that serve as universal building blocks to a variety of substituted pyran systems. It has already proven its value in the synthesis of several fragments of maitotoxin, including the GHIJKLMNO domain (Figure 44) that was used to provide compelling support, through ${ }^{13} \mathrm{C}$ NMR comparisons with the natural product, for the originally proposed structure of maitotoxin (Figure 42 ). ${ }^{118}$ The continually expanding saga of the ladderlike polyether marine biotoxins has recently been reviewed. ${ }^{119}$

This new asymmetric method for the synthesis of substituted tetrahydropyrans allows us to utilize prochiral starting materials for the synthesis of the polyether marine biotoxins instead of the traditionally used carbohydrate option. Stephen Hanessian merits special mention here as a pioneer of the latter approach ${ }^{120}$ to organic synthesis in general, and total synthesis in particular, which relies on the chiral pool (naturally occurring compounds) to provide enantiopure starting materials for synthetic endeavors of all kinds (see total syntheses of brevetoxins A and B, Figures 35-41).

The impact of the work of Ryoji Noyori goes much beyond the asymmetric reduction applied here as well as in our uncialamycin project mentioned earlier (see Figure 18). Indeed, his influential research and leadership inspired not only his compatriots in Japan, but also chemists around the world who collectively made further advances in the field of asymmetric catalysis, especially asymmetric hydrogenation, that impacted enormously both academic and pharmaceutical research. As already mentioned, Noyori shared the 2001 Nobel Prize in Chemistry with Knowles and Sharpless (see Table 1).

Finally, I would be remiss if I did not mention the enormous impact that the hydroboration and Wittig reactions, and their modifications, have had on the development of organic synthesis in general and the art of total synthesis in particular. Indeed, few total syntheses could have been accomplished as elegantly without these powerful reactions. Their inventors, H. C. Brown and Georg Wittig, shared the 1979 Nobel Prize in Chemistry (see Table 1).

\section{Conclusion and Future Perspectives}

The first one hundred years of the Organic Chemistry Division of the American Chemical Society (1908-2008) saw an unprecedented growth in the power and scope of the science of organic chemistry. Some of the most spectacular progress occurred in chemical synthesis in general and total synthesis in particular. Although the achievements are too many to mention, one can clearly recognize the increase in the power of the methods and tools, and the molecular complexity that can be reached in the laboratory. As seen earlier, Table 1 lists the Nobel Prizes that have been awarded to date in the field of organic synthesis and related disciplines along with the citations for the work recognized, and provides a general snapshot of the gradient of the art and science of total synthesis, organic synthesis, and organic chemistry. It is interesting to note that while no Americans are found on the list prior to 1965, that year marks a change. That change, of which the Organic Division of the American Chemical Society must be proud, is reflected in the 17 Nobel Laureates whose award winning work has been done in the United States since then.

With such record of accomplishment and height in power, one may ask what is next for chemical synthesis. While wishes may be expressed accurately, predictions are more risky, 
especially when they pertain to such a dynamic and ubiquitous discipline as that of chemical synthesis, where serendipity still plays a major role in discovery. However, a few measured words on the subject of future perspectives are both in order and expected. First and foremost, synthesis has to be viewed as an art and a science that needs to be advanced for its own sake. Deficiencies certainly exist and become stark when we compare our present capabilities with those of nature in terms of efficiency and unwanted byproducts. Improvements are clearly needed with regard to strategies and tactics. Availability of raw materials and sustainability concerns dictate the discovery and development of new synthetic methods and technologies for the conversion of renewable natural materials beyond petroleum and other traditional sources into high value and much needed products such as pharmaceuticals, nutritional foods and supplements, and advanced materials. Converting carbon dioxide back to more valuable organic molecules is a challenge waiting to be answered, and green chemistry should be pursued seriously for the sake of the planet. The goal should be the development of chemistry through which renewable natural resources can be converted to high value products cleanly and efficiently, and in harmony with nature for the benefit of society.

In order to serve humanity optimally and to fully exploit its power, chemical synthesis must also be focused on, and become the awesome tool in, other areas and disciplines. Thus, expanding its reach beyond its traditional boundaries in chemicals and pharmaceuticals, synthesis can help push the envelope and shape the new frontiers in biology and physics, and in biotechnology and nanotechnology. For these fundamental and applied breakthroughs to occur, we will need to inspire the youth of the world to enter into the science of chemistry and related disciplines. As teachers, we are well positioned to do that, but we will need to do more to change the eroding perception and image of chemistry, and to convince the leaders and administrators in academic, industrial, and governmental institutions as to the crucial and instrumental role of chemistry to technological innovation and human prosperity. If the innovation and impact of organic synthesis on society in the last century is a measure of things to come, we are in for a new wave of influential discoveries and inventions. How well they will serve humanity and the planet will depend on how wisely we use them.

\section{Acknowledgements}

It is with enormous pride and great pleasure that we wish to thank our collaborators whose names appear in the references cited and whose contributions made the described work so enjoyable and rewarding. I also wish to thank Jason S. Chen for his invaluable assistant in preparing this Perspective. We gratefully acknowledge the National Institutes of Health (USA), the National Science Foundation, the Skaggs Institute for Research, Amgen, and Merck for supporting our research programs. The photographs included in these pages are from my personal collection.

\section{References and Footnotes}

1. Nicolaou KC, Vourloumis D, Winssinger N, Baran PS. Angew Chem, Int Ed 2000;39:44.

2. Nicolaou, KC.; Sorensen, EJ. Classics in Total Synthesis. VCH; Weinheim: 1996. p. 798Nicolaou, KC.; Snyder, SA. Classics in Total Synthesis II. Wiley-VCH; Weinheim: 2003. p. 658

3. Bandaranayake WM, Banfield JE, Black DStC, Fallon GD, Gatehouse BM. J Chem Soc, Chem Commun 1980:162.

4. Bandaranayake WM, Banfield JE, Black DStC. J Chem Soc, Chem Commun 1980:902.

5. (a) Meister H. Chem Ber 1963;96:1688. (b) Marvell EN, Seubert J. J Am Chem Soc 1967;89:3377. (c) Huisgen R, Dahmen A, Huber H. J Am Chem Soc 1967;89:7130. (d) Marvell EN, Seubert J, Vogt G, Zimmer G, Moy G, Siegmann JR. Tetrahedron 1978;34:1323.

6. (a) Oppolzer W. Angew Chem, Int Ed Engl 1977;16:10. (b) Roush WR. J Org Chem 1979;44:4008.

7. Diels O, Alder K. Justus Liebigs Ann Chem 1928;460:98.

8. (a) Robinson R. J Chem Soc, Trans 1917:762.See also: (b) Birch AJ. Notes Records Royal Soc London 1993;47:277. 
9. (a) Johnson WS, Gravestock MB, Parry RJ, Myers RF, Bryson TA, Miles DH. J Am Chem Soc 1971;93:4330. (b) Johnson WS, Gravestock MB, McCarry BE. J Am Chem Soc 1971;93:4332. [PubMed: 5131151] (c) Gravestock MB, Johnson WS, McCarry BE, Parry RJ, Ratcliffe BE. J Am Chem Soc 1978;100:4274.

10. (a) Stork G, Burgstahler AW. J Am Chem Soc 1955;77:5068. (b) Eschenmoser A, Ruzicka L, Jeger O, Arigoni D. Helv Chim Acta 1955;38:1890. (c) Stadler PA, Eschenmoser A, Schinz H, Stork G. Helv Chim Acta 1957;40:2191.

11. (a) Nicolaou KC, Petasis NA, Zipkin RE, Uenishi J. J Am Chem Soc 1982;104:5555. (b) Nicolaou KC, Petasis NA, Uenishi J, Zipkin RE. J Am Chem Soc 1982;104:5557.

12. (a) Nicolaou KC, Zipkin RE, Petasis NA. J Am Chem Soc 1982;104:5558. (b) Nicolaou KC, Petasis NA, Zipkin RE. J Am Chem Soc 1982;104:5560.

13. (a) Banfield JE, Black DSC, Johns SR, Willing RI. Aust J Chem 1982;35:2247. (b) Banfield JE, Black DSC, Fallon GD, Gatehouse BM. Aust J Chem 1983;36:627.

14. Parker KA, Lim YH. J Am Chem Soc 2004;126:15968. [PubMed: 15584723]

15. (a) Jacobsen MF, Moses JE, Adlington RM, Baldwin JE. Org Lett 2005;7:2473. [PubMed: 15932226] (b) Jacobsen MF, Moses JE, Adlington RM, Baldwin JE. Tetrahedron 2006;62:1675.

16. (a) Beaudry CM, Trauner D. Org Lett 2005;7:4475. [PubMed: 16178562] (b) Miller AK, Trauner D. Angew Chem, Int Ed 2005;44:4602. (c) Miller AK, Trauner D. Synlett 2006:2295.

17. (a) Nicolaou KC, Simonsen KB, Vassilikogiannakis G, Baran PS, Vidali VP, Pitsinos EN, Couladouros EA. Angew Chem, Int Ed 1999;38:3555. (b) Nicolaou KC, Vassilikogiannakis G, Simonsen KB, Baran PS, Zhong YL, Vidali VP, Pitsinos EN, Coulaouros EA. J Am Chem Soc 2000;122:3071.

18. (a) Nicolaou KC, Baran PS, Zhong YL, Fong KC, He Y, Yoon WH, Choi HS. Angew Chem, Int Ed 1999;38:1669. (b) Nicolaou KC, Baran PS, Zhong YL, Fong KC, He Y, Yoon WH, Choi HS. Angew Chem, Int Ed 1999;38:1676. (c) Nicolaou KC, Jung JK, Yoon WH, He Y. Angew Chem, Int Ed 2000;39:1829. (d) Nicolaou KC, Jung JK, Yoon WH, Fong KC, Choi HS, Zhong YL, Baran PS. J Am Chem Soc 2002;124:2183. [PubMed: 11878972] (e) Nicolaou KC, Baran PS, Zhong YL, Fong KC, Choi HS. J Am Chem Soc 2002;124:2190. [PubMed: 11878973] (f) Nicolaou KC, Zhong YL, Baran PS, Jung JK, Choi HS, Yoon WH. J Am Chem Soc 2002;124:2202. [PubMed: 11878974]

19. (a) Nicolaou KC, Vassilikogiannakis G, Mägerlein W, Kranich R. Angew Chem, Int Ed 2001;40:2482. (b) Nicolaou KC, Vassilikogiannakis G, Mägerlein W, Kranich R. Chem Eur J 2001;7:5359.

20. (a) Nicolaou KC, Gray DLF. Angew Chem, Int Ed 2001;40:761. (b) Nicolaou KC, Gray DLF. J Am Chem Soc 2004;126:607. [PubMed: 14719960]

21. (a) Nicolaou KC, Bella M, Chen DYK, Huang X, Ling T, Snyder SA. Angew Chem, Int Ed 2002;41:3495. (b) Nicolaou KC, Chen DYK, Huang X, Ling T, Bella M, Snyder SA. J Am Chem Soc 2004;126:12888. [PubMed: 15469286] (c) Nicolaou KC, Bheema Roa P, Hao J, Reddy MV, Rassias G, Huang X, Chen DY-K, Snyder SA. Angew Chem, Int Ed 2003;42:1753. (d) Nicolaou KC, Hao J, Reddy MV, Bheema Roa P, Rassias G, Snyder SA, Huang X, Chen DY-K, Brenzovich WE, Giuseppone N, Giannakakou P, O’Brate A. J Am Chem Soc 2004;126:12897. [PubMed: 15469287]

22. (a) Nicolaou KC, Sasmal PK, Xu H, Namoto K, Ritzén A. Angew Chem, Int Ed 2003;42:4255. (b) Nicolaou KC, Sasmal PK, Xu H. J Am Chem Soc 2004;126:5493. [PubMed: 15113221]

23. (a) Nicolaou KC, Nevalainen M, Safina BS, Zak M, Bulat S. Angew Chem, Int Ed 2002;41:1941. (b) Nicolaou KC, Safina BS, Zak M, Estrada AA, Lee SH. Angew Chem, Int Ed 2004;43:5087. (c) Nicolaou KC, Safina BS, Zak M, Lee SH, Estrada AA. Angew Chem, Int Ed 2004;43:5092. (d) Nicolaou KC, Safina BS, Zak M, Lee SH, Nevalainen M, Bella M, Estrada AA, Funke C, Zécri FJ, Bulat S. J Am Chem Soc 2005;127:11159. [PubMed: 16076224] (e) Nicolaou KC, Zak M, Safina BS, Estrada AA, Lee SH, Nevalainen M. J Am Chem Soc 2005;127:11176. [PubMed: 16076225]

24. (a) Nicolaou KC, Pihko PM, Diedrichs N, Zou N, Bernal F. Angew Chem, Int Ed 2001;40:1262. (b) Nicolaou KC, Qian W, Bernal F, Uesaka N, Pihko PM, Hinrichs J. Angew Chem, Int Ed 2001;40:4068. (c) Nicolaou KC, Li Y, Uesaka N, Koftis TV, Vyskocil S, Ling T, Govindasamy M, Qian W, Bernal F, Chen DYK. Angew Chem, Int Ed 2003;42:3643. (d) Nicolaou KC, Chen DYK, Li Y, Ling T, Vyskocil S, Koftis TV, Govindasamy M, Uesaka N. Angew Chem, Int Ed 2003;42:3649. (e) Nicolaou KC, Vyskocil S, Koftis TV, Yamada YMA, Ling T, Chen DYK, Tang W, Petrovic G, Frederick MO, Li Y, Satake M. Angew Chem, Int Ed 2004;43:4312. (f) Nicolaoau 
KC, Koftis TV, Vyskocil S, Petrovic G, Ling T, Yamada YMA, Tang W, Frederick MO. Angew Chem, Int Ed 2004;43:4318. (g) Nicolaou KC, Pihko PM, Bernal F, Frederick MO, Qian W, Uesaka N, Diedrichs N, Hinrichs J, Koftis TV, Loizidou E, Petrovic G, Rodriguez M, Sarlah D, Zou N. J Am Chem Soc 2006;128:2244. [PubMed: 16478178] (h) Nicolaou KC, Chen DYK, Li Y, Uesaka N, Petrovic G, Koftis TV, Bernal F, Frederick MO, Govindasamy M, Ling T, Pihko PM, Tang W, Vyskocil S. J Am Chem Soc 2006;128:2258. [PubMed: 16478179] (i) Nicolaou KC, Koftis TV, Vyskocil S, Petrovic G, Tang W, Frederick MO, Chen DYK, Li Y, Yamada YMA. J Am Chem Soc 2006;128:2259. (j) Nicolaou KC, Frederick MO, Petrovic G, Cole KP, Loizidou E. Angew Chem, Int Ed 2006;45:2609. (k) Nicolaou KC, Frederick MO, Loizidou E, Petrovic G, Cole KP, Koftis TV, Yamada Y, Yoichi MA. Chem Asian J 2006;1:245. [PubMed: 17441061]

25. (a) Nicolaou KC, Papageorgiou CD, Piper JL, Chadha RK. Angew Chem, Int Ed 2005;44:5846. (b) Nicolaou KC, Lim YH, Papageorgiou CD, Piper JL. Angew Chem, Int Ed 2005;44:7917. (c) Nicolaou KC, Lim YH, Piper JL, Papageorgiou CD. J Am Chem Soc 2007;129:4001. [PubMed: 17355133]

26. Nicolaou KC, Sarlah D, Shaw DM. Angew Chem, Int Ed 2007;46:4708.

27. (a) Nicolaou KC, Lister T, Denton RM, Gelin CF. Angew Chem, Int Ed 2007;46:7501. (b) Nicolaou KC, Lister T, Denton RM, Gelin CF. Tetrahedron 2008;64:4736.

28. For selected reviews, see: (a) Nicolaou KC, Montagnon T, Snyder SA. Chem Commun 2003:551. (b) Nicolaou KC, Edmonds DJ, Bulger PG. Angew Chem, Int Ed 2006;45:7134.

29. (a) Woodward RB. Pure Appl Chem 1968;17:519. [PubMed: 5729287] (b) Woodward RB. Pure Appl Chem 1971;25:283. [PubMed: 5095424] (c) Woodward RB. Pure Appl Chem 1973;33:145. [PubMed: 4684454] (d) Eschenmoser A. Quart Rev 1970;24:366. (e) Eschenmoser A. Pure Appl Chem, Suppl 1971;2:69. (f) Eschenmoser A. Naturwissenschaften 1974;61:513. [PubMed: 4453344] (g) Eschenmoser A, Wintner CE. Science 1977;196:1410. [PubMed: 867037]

30. Fischer H, Zeile K. Justus Liebigs Ann Chem 1929;468:98.

31. (a) Lee MD, Dunne TS, Siegel MM, Chang CC, Morton GO, Borders DB. J Am Chem Soc 1987; 109:3464. (b) Lee MD, Dunne TS, Chang CC, Ellestad GA, Siegel MM, Morton GO, McGahren WJ, Borders DB. J Am Chem Soc 1987;109:3466. (c) Lee MD, Manning JK, Williams DR, Kuck NA, Testa RT, Borders DB. J Antibiot 1989;62:1070. [PubMed: 2753814] (d) Lee MD, Ellestad GA, Borders DB. Acc Chem Res 1991;24:235. (e) Lee MD, Dunne TS, Chang CC, Siegel MM, Morton GO, Ellestad GA, McGahren WJ, Borders DB. J Am Chem Soc 1992;114:985.

32. (a) Jones RR, Bergman RG. J Am Chem Soc 1972;94:660. (b) Bergman RG. Acc Chem Res 1973;6:25.

33. Darby N, Kim CU, Salaün JA, Shelton KW, Takada S, Masamune S. J Chem Soc D, Chem Commun 1971:1516.

34. Wong HNC, Sondheimer F. Tetrahedron Lett 1980;21:217.

35. (a) Nicolaou KC, Groneberg RD, Miyazaki T, Stylianides NA, Schulze TJ, Stahl W. J Am Chem Soc 1990;112:8193. (b) Smith AL, Hwang CK, Pitsinos E, Scarlato G, Nicolaou KC. J Am Chem Soc 1992;114:3134. (c) Nicolaou KC, Hummel CW, Pitsinos EN, Nakada M, Smith AL, Shibayama K, Saimoto H. J Am Chem Soc 1992;114:10082. (d) Groneberg RD, Miyazaki T, Stylianides NA, Schulze TJ, Stahl W, Schreiner EP, Suzuki T, Iwabuchi Y, Smith AL, Nicolaou KC. J Am Chem Soc 1993;115:7593. (e) Smith AL, Pitsinos EN, Hwang CK, Mizuno Y, Saimoto H, Scarlato GR, Suzuki T, Nicolaou KC. J Am Chem Soc 1993;115:7612. (f) Nicolaou KC, Hummel CW, Nakada M, Shibayama K, Pitsinos EN, Saimoto H, Mizuno Y, Baldenius KU, Smith AL. J Am Chem Soc 1993;115:7625. (g) Nicolaou KC. Angew Chem, Int Ed Engl 1993;32:1377.

36. (a) Nicolaou KC, Zuccarello G, Ogawa Y, Schweiger EJ, Kumazawa T. J Am Chem Soc 1988;110:4866. (b) Nicolaou KC, Ogawa Y, Zuccarello G, Kataoka H. J Am Chem Soc 1988;110:7247. (c) Nicolaou KC, Zuccarello G, Riemer C, Estevez VA, Dai WM. J Am Chem Soc 1992;114:7360.

37. (a) Nicolaou KC, Hwang CK, Smith AL, Wendeborn SV. J Am Chem Soc 1990;112:7416. (b) Nicolaou KC, Dai WM, Tsay SC, Estevez VA, Wrasidlo W. Science 1992;256:1172. [PubMed: 1589797] (c) Nicolaou KC, Maligres P, Suzuki T, Wendeborn SV, Dai WM, Chadha RK. J Am Chem Soc 1992;114:8890. (d) Nicolaou KC, Dai WM. J Am Chem Soc 1992;114:8908. (e) Nicolaou KC, Smith AL, Yue EW. Proc Natl Acad Sci USA 1993;90:5881. [PubMed: 8327459] 
38. (a) Nicolaou KC, Skokotas G, Maligres P, Zuccarello G, Schweiger EJ, Toshima K, Wendeborn S. Angew Chem, Int Ed Engl 1989;28:1272. (b) Nicolaou KC, Wendeborn S, Maligres P, Isshiki K, Zein N, Ellestad G. Angew Chem, Int Ed Engl 1991;30:418.

39. For selected reviews, see: (a) Nicolaou KC, Dai WM. Angew Chem, Int Ed Engl 1991;30:1387. (b) Smith AL, Nicolaou KC. J Med Chem 1996;39:2103. [PubMed: 8667354] (c) Jones GB, Fouad FS. Curr Pharm Des 2002;8:2415. [PubMed: 12369941]

40. (a) Nicolaou KC, Schreiner EP, Iwabuchi Y, Suzuki T. Angew Chem, Int Ed Engl 1992;31:340. (b) Gomez-Paloma L, Smith JA, Chazin WJ, Nicolaou KC. J Am Chem Soc 1994;116:3697. (c) Li T, Zeng Z, Estevez VA, Baldenius KU, Nicolaou KC, Joyce GF. J Am Chem Soc 1994;116:3709. (d) Nicolaou KC, Ajito K, Komatsu H, Smith BM, Li T, Egan MG, Gomez-Paloma L. Angew Chem, Int Ed Engl 1995;34:576. (e) Liu C, Smith BM, Ajito K, Komatsu H, Gomez-Paloma L, Li T, Theodorakis EA, Nicolaou KC, Vogt PK. Proc Natl Acad Sci USA 1996;93:940. [PubMed: 8570664] (f) Nicolaou KC, Ajito K, Komatsu H, Smith BM, Bertinato P, Gomez-Paloma L. Chem Commun 1996:1495. (g) Nicolaou KC, Smith BM, Ajito K, Komatsu H, Gomez-Paloma L, Tor Y. J Am Chem Soc 1996;118:2303. (h) Bifulco G, Galeone A, Gomez-Paloma L, Nicolaou KC, Chazin WJ. J Am Chem Soc 1996;118:8817. (i) Nicolaou KC, Smith BM, Pastor J, Watanabe Y, Weinstein DS. Synlett 1997:401. (j) Bifulco G, Galeone A, Nicolaou KC, Chazin WJ, Gomez-Paloma L. J Am Chem Soc 1998; $120: 7183$.

41. Nicolaou KC, Ebata T, Stylianides NA, Groneberg RD, Carrol PJ. Angew Chem, Int Ed Engl 1988;27:1097.

42. (a) Hitchcock SA, Boyer SH, Chu-Moyer MY, Olson SH, Danishefsky SJ. Angew Chem, Int Ed 1994;33:858. (b) Halcomb RL, Boyer SH, Wittman MD, Olson SH, Denhart DJ, Liu KKC, Danishefsky SJ. J Am Chem Soc 1995;117:5720. (c) Hitchcock SA, Chu-Moyer MY, Boyer SH, Olson SH, Danishefsky SJ. J Am Chem Soc 1995;117:5750. (d) Danishefsky SJ, Shair MD. J Org Chem 1996;61:16.

43. For example, N1999A2: (a) Ando T, Ishii M, Kajiura T, Kameyama T, Miwa K, Sugiura Y. Tetrahedron Lett 1998;39:6495. (b) Miyagawa N, Sasaki D, Matsuoka M, Imanishi M, Ando T, Sugiura Y. Biochem Biophys Res Commun 2003;306:87. [PubMed: 12788070]Shishijimicins A-C: (c) Oku N, Matsunaga S, Fusetani N. J Am Chem Soc 2003;125:2044. [PubMed: 12590521] Uncialamycin: (d) Davies J, Wang H, Taylor T, Warabi K, Huang XH, Andersen RJ. Org Lett 2005;7:5233. [PubMed: 16268546]

44. (a) Myers AG, Fraley ME, Tom NJ, Cohen SB, Madar DJ. Chem Biol 1995;2:33. [PubMed: 9383401] (b) Myers AG, Tom NJ, Fraley ME, Cohen SB, Madar DJ. J Am Chem Soc 1997;119:6072.

45. (a) Shair MD, Yoon TY, Danishefsky SJ. Angew Chem, Int Ed Engl 1995;34:1721. (b) Shair MD, Yoon TY, Mosny KK, Chou TC, Danishefsky SJ. J Am Chem Soc 1996;118:9509.

46. (a) Myers AG, Liang J, Hammond M, Harrington PM, Wu Y, Kou EY. J Am Chem Soc 1998;120:5319. (b) Myers AG, Glatthar R, Hammond M, Harrington PM, Kou EY, Liang J, Schaus SE, Wu Y, Xiang JN. J Am Chem Soc 2002;124:5380. [PubMed: 11996579]

47. Kobayashi S, Hori M, Wang GX, Hirama M. J Org Chem 2006;71:636. [PubMed: 16408974]

48. (a) Kobayashi S, Reddy RS, Sugiura Y, Sasaki D, Miyagawa N, Hirama M. J Am Chem Soc 2001;123:2887. [PubMed: 11456978] (b) Kobayashi S, Ashizawa S, Takahashi Y, Sugiura Y, Nagaoka M, Lear MJ, Hirama M. J Am Chem Soc 2001;123:11294. [PubMed: 11697974]

49. Ji N, O’Dowd H, Rosen BM, Myers AG. J Am Chem Soc 2006;128:14825. [PubMed: 17105291]

50. Ren F, Hogan PC, Anderson AJ, Myers AG. J Am Chem Soc 2007;129:5381. [PubMed: 17417855]

51. Komano K, Shimamura S, Inoue M, Hirama M. J Am Chem Soc 2007;129:14184. [PubMed: 17956103]

52. Nicolaou KC, Zhang H, Chen JS, Crawford JJ, Pasunoori L. Angew Chem, Int Ed 2007;46:4704. 53. Nicolaou KC, Chen JS, Zhang H, Montero A. Angew Chem, Int Ed 2008;47:185.

54. Wani MC, Taylor HL, Wall ME, Coggon P, McPhail AT. J Am Chem Soc 1971;93:2325. [PubMed: 5553076]

55. (a) Schiff PB, Fant J, Horwitz SB. Nature 1979;277:665. [PubMed: 423966] (b) Schiff PB, Horwitz SB. Proc Natl Acad Sci USA 1980;77:1561. [PubMed: 6103535]

56. Cragg GM, Schepartz SA, Suffness M, Grever MR. J Nat Prod 1993;56:1657. [PubMed: 7903979] 
57. (a) Corey EJ, Kang MC, Desai MC, Ghosh AK, Houpis IN. J Am Chem Soc 1988;110:649.Desai, MC.; Ghosh, AK.; Kang, M-C.; Houpis, IN. Strategies and Tactics in Organic Synthesis. Lindberg, T., editor. Vol. 3. Academic Press; New York: 1991. p. 89-119. (c) Corey EJ, Gavai AV. Tetrahedron Lett 1988;29:3201.

58. (a) Nicolaou KC, Yang Z, Liu JJ, Ueno H, Nantermet PG, Guy RK, Claiborne CF, Renaud J, Couladouros EA, Paulvannan K, Sorensen EJ. Nature 1994;367:630. [PubMed: 7906395] (b) Nicolaou KC, Nantermet PG, Ueno H, Guy RK, Couladouros EA, Sorensen EJ. J Am Chem Soc 1995;117:624. (c) Nicolaou KC, Liu JJ, Yang Z, Ueno H, Sorensen EJ, Claiborne CF, Guy RK, Hwang CK, Nakada M, Nantermet PG. J Am Chem Soc 1995;117:634. (d) Nicolaou KC, Yang Z, Liu JJ, Nantermet PG, Claiborne CF, Renaud J, Guy RK, Shibayama K. J Am Chem Soc 1995;117:645. (e) Nicolaou KC, Ueno H, Liu JJ, Nantermet PG, Yang Z, Renaud J, Paulvannan K, Chadha R. J Am Chem Soc 1995;117:653. (f) Nicolaou KC, Guy RK. Angew Chem, Int Ed Engl 1995;34:2079.

59. Narasaka K, Shimada S, Osoda K, Iwasawa N. Synthesis 1991:1171.

60. (a) Shapiro RH, Heath MJ. J Am Chem Soc 1967;89:5734. (b) Shapiro RH. Org React 1976;23:405.

61. (a) McMurry JE, Fleming MP. J Am Chem Soc 1974;96:4708. [PubMed: 4850242] (b) McMurry JE, Fleming MP, Kees KL, Krepski LR. J Org Chem 1978;43:3255. (c) McMurry JE. Acc Chem Res 1983;16:405. (d) McMurry JE. Chem Rev 1989;89:1513.

62. Holton RA. Eur. Pat. Appl. EP400, 971. Chem Abstr 1991;114:164568q.

63. (a) Ojima I, Habus I, Zhao M. J Org Chem 1991;56:1681. (b) Ojima I, Habus I, Zhao M, Zucco M, Park YH, Sun CM, Brigaud T. Tetrahedron 1992;48:6985. (c) Ojima I, Sun CM, Zucco M, Park YH, Duclos O, Kuduk S. Tetrahedron Lett 1993;34:4149.

64. (a) Nicolaou KC, Riemer C, Kerr MA, Rideout D, Wrasidlo W. Nature 1993;364:464. [PubMed: 8101355] (b) Nicolaou KC, Couladouros EA, Nantermet PG, Renaud J, Guy RK, Wrasidlo W. Angew Chem, Int Ed Engl 1994;33:1581. (c) Nicolaou KC, Guy RK, Pitsinos EN, Wrasidlo W. Angew Chem, Int Ed Engl 1994;33:1583. (d) Nicolaou KC, Claiborne CF, Nantermet PG, Couladouros EA, Sorensen EJ. J Am Chem Soc 1994;116:1591. (e) Guy RK, Scott ZA, Sloboda RD, Nicolaou KC. Chem Biol 1996;3:1021. [PubMed: 9000007] (f) Nicolaou KC, Claiborne CF, Paulvannan K, Postema MHD, Guy RK. Chem Eur J 1997;3:399.

65. (a) Holton RA, Somoza C, Kim HB, Liang F, Biediger RJ, Boatman PD, Shindo M, Smith CC, Kim S, Nadizadeh H, Suzuki Y, Tao C, Vu P, Tang S, Zhang P, Murthi KK, Gentile LN, Liu JH. J Am Chem Soc 1994;116:1597. (b) Holton RA, Kim HB, Somoza C, Liang F, Biediger RJ, Boatman PD, Shindo M, Smith CC, Kim S, Nadizadeh H, Suzuki Y, Tao C, Vu P, Tang S, Zhang P, Murthi KK, Gentile LN, Liu JH. J Am Chem Soc 1994;116:1599. (c) Holton RA, Somoza C, Kim HB, Liang F, Biediger RJ, Boatman PD, Shindo M, Smith CC, Kim S, Nadizadeh H, Suzuki Y, Tao C, Vu P, Tang S, Zhang P, Murthi KK, Gentile LN, Liu JH. ACS Symp Ser 1995;583:288.

66. (a) Masters JJ, Link JT, Snyder LB, Young WB, Danishefsky SJ. Angew Chem, Int Ed Engl 1995;34:1723. (b) Danishefsky SJ, Masters JJ, Young WB, Link JT, Snyder LB, Magee TV, Jung DK, Isaacs RCA, Bornmann WG, Alaimo CA, Coburn CA, Di Grandi MJ. J Am Chem Soc 1996;118:2843.

67. (a) Wender PA, Badham NF, Conway SP, Floreancig PE, Glass TE, Gränicher C, Houze JB, Jänichen J, Lee D, Marquess DG, McGrane PL, Meng W, Mucciaro TP, Mühlebach M, Natchus MG, Paulsen H, Rawlins DB, Satkofsky J, Shuker AJ, Sutton JC, Taylor RE, Tomooka K. J Am Chem Soc 1997;119:2755. (b) Wender PA, Badham NF, Conway SP, Floreancig PE, Glass TE, Houze JB, Krauss NE, Lee D, Marquess DG, McGrane PL, Meng W, Natchus MG, Shuker AJ, Sutton JC, Taylor RE. J Am Chem Soc 1997;119:2757.

68. (a) Shiina I, Iwadare H, Sakoh H, Hasegawa M, Tani YI, Mukaiyama T. Chem Lett 1998:1. (b) Shiina I, Saitoh K, Fréchard-Ortuno I, Mukaiyama T. Chem Lett 1998:3. (c) Mukaiyama T, Shiina I, Iwadare H, Saitoh M, Nishimura T, Ohkawa N, Sakoh H, Nishimura K, Tani YI, Hasegawa M, Yamada K, Saitoh K. Chem Eur J 1999;5:121.

69. (a) Morihira K, Hara R, Kawahara S, Nishimori T, Nakamura N, Kusama H, Kuwajima I. J Am Chem Soc 1998;120:12980. (b) Kuwajima I, Kusama H. Synlett 2000:1385.

70. Lin YY, Risk M, Ray SM, Van Engen D, Clardy J, Golik J, James JC, Nakanishi K. J Am Chem Soc 1981;103:6773.

71. Anderson DM. Sci Am 1994;8:62. [PubMed: 8066432] 
72. (a) Shimizu Y, Chou HN, Bando H, Van Duyne G, Clardy JC. J Am Chem Soc 1986;108:514. (b) Shimizu Y, Chou HN, Bando H, Van Duyne G, Clardy JC. J Chem Soc, Chem Commun 1986:1656. (c) Pawlak J, Tempesta MS, Golik J, Zagorski MG, Lee MS, Nakanishi K, Iwashita T, Gross ML, Tomer KB. J Am Chem Soc 1987;109:1144.

73. (a) This hypothetical strategy for the synthesis of brevetoxin B was proposed in a grant application to the National Institutes of Health (NIH) (U.S.A.) by the author in 1982 (GM31398-01, receipt date February 24, 1982). See also: Nicolaou KC. Angew Chem, Int Ed Engl 1996;35:589.

74. (a) Nakanishi K. Toxicon 1985;23:473. [PubMed: 3895583] (b) Lee MS, Qin GW, Nakanishi K, Zagorski MG. J Am Chem Soc 1989;111:6234.

75. Vilotijevic I, Jamison TF. Science 2007;317:1189. [PubMed: 17761875]

76. (a) Nicolaou KC, Duggan ME, Hwang CK, Somers PK. J Chem Soc, Chem Commun 1985:1359. (b) Nicolaou KC, Prasad CVC, Somers PK, Hwang CK. J Am Chem Soc 1989;111:5330. (c) Nicolaou KC, Prasad CVC, Somers PK, Hwang CK. J Am Chem Soc 1989;111:5335.

77. Baldwin JE. J Chem Soc, Chem Commun 1976:734.

78. (a) Katsuki T, Sharpless KB. J Am Chem Soc 1980;102:5974. (b) Gao Y, Klunder JM, Hanson RM, Ko SY, Masamune H, Sharpless KB. J Am Chem Soc 1987;109:5765.

79. (a) Nicolaou KC, Duggan ME, Hwang CK. J Am Chem Soc 1986;108:2468. (b) Nicolaou KC, Prasad CVC, Hwang C-K, Duggan ME, Veale CA. J Am Chem Soc 1989;111:5321.

80. (a) Nicolaou KC, Hwang C-K, Duggan ME, Bal Reddy K, Marron BE, McGarry DG. J Am Chem Soc 1986;108:6800. (b) Nicolaou KC, Hwang CK, Duggan ME, Carroll PJ. J Am Chem Soc 1987;109:3801. (c) Nicolaou KC, Hwang CK, DeFrees SA, Stylianides NA. J Am Chem Soc 1988;110:4868. (d) Nicolaou KC, Hwang CK, Marron BE, DeFrees SA, Couladouros EA, Abe Y, Carroll PJ, Snyder JP. J Am Chem Soc 1990;112:3040. (e) Nicolaou KC, DeFrees SA, Hwang CK, Stylianides N, Carroll PJ, Snyder JP. J Am Chem Soc 1990;112:3029.

81. (a) Nicolaou KC, Hwang CK, Nugiel DA. Angew Chem, Int Ed Engl 1988;27:1362. (b) Nicolaou KC, Hwang CK, Nugiel DA. J Am Chem Soc 1989;111:4136.

82. (a) Nicolaou KC, McGarry DG, Somers PK, Veale CA, Furst GT. J Am Chem Soc 1987;109:2504. (b) Nicolaou KC, McGarry DG, Somers PK, Kim BH, Ogilvie WW, Yiannikouros G, Prasad CVC, Veale CA, Hark RR. J Am Chem Soc 1990;112:6263.

83. (a) Sassaman MB, Kotian KD, Prakash GKS, Olah GA. J Org Chem 1987;52:4314. (b) Sassaman MB, Prakash GKS, Olah GA, Donald P, Loker KB. Tetrahedron 1988;44:3771.

84. Evans PA, Cui J, Gharpure SJ, Hinkle RJ. J Am Chem Soc 2003;125:11456. [PubMed: 13129322]

85. Sato K, Sasaki M. Tetrahedron 2007;63:5977.

86. (a) Katz TJ, Lee SJ, Shippey MA. J Mol Catal 1980;8:219. (b) Howard TR, Lee JB, Grubbs RH. J Am Chem Soc 1980;102:6876. (c) Fu GC, Grubbs RH. J Am Chem Soc 1992;114:5426. (d) Fu GC, Nguyen ST, Grubbs RH. J Am Chem Soc 1993;115:9856. (e) Fujimura O, Fu GC, Grubbs RH. J Org Chem 1994;59:4029.For a review of olefin metathesis see: (f) Nicolaou KC, Bulger PG, Sarlah D. Angew Chem, Int Ed 2005;44:4490.

87. Nicolaou KC, Postema MHD, Claiborne CF. J Am Chem Soc 1996;118:1565.

88. (a) Tebbe FN, Parshall GW, Reddy GS. J Am Chem Soc 1978;100:3611. (b) Pine SH, Zahler R, Evans DA, Grubbs RH. J Am Chem Soc 1980;102:3270.

89. Nicolaou KC, Postema MHD, Yue EW, Nadin A. J Am Chem Soc 1996;118:10335.

90. (a) Tsushima K, Araki K, Murai A. Chem Lett 1989:1313. (b) Tsushima K, Murai A. Chem Lett 1990:761.

91. Nicolaou KC, Shi GQ, Gunzner JL, Gärtner P, Yang Z. J Am Chem Soc 1997;119:5467.

92. (a) Sasaki M, Fuwa H, Ishikawa M, Tachibana K. Org Lett 1999;1:1075. For a review on the B-alkyl Suzuki reaction see: (b) Chemler SR, Trauner D, Danishefsky SJ. Angew Chem, Int Ed 2001;40:4544.

93. Nicolaou KC, Shi GQ, Namoto K, Bernal F. Chem Commun 1998:1757.

94. (a) Nicolaou KC, Duggan ME, Hwang CK. J Am Chem Soc 1989;111:6666. (b) Nicolaou KC, Duggan ME, Hwang CK. J Am Chem Soc 1989;111:6676. (c) Nicolaou KC, Hwang CK, Duggan ME. J Am Chem Soc 1989;111:6682. (d) Nicolaou KC, Nugiel DA, Couladouros E, Hwang CK. Tetrahedron 1990;46:4517. (e) Nicolaou KC, Tiebes J, Theodorakis EA, Rutjes FPJT, Koide K, Sato M, Untersteller E. J Am Chem Soc 1994;116:9371. (f) Nicolaou KC, Theodorakis EA, Rutjes FPJT, 
Tiebes J, Sato M, Untersteller E, Xiao XY. J Am Chem Soc 1995;117:1171. (g) Nicolaou KC, Rutjes FPJT, Theodorakis EA, Tiebes J, Sato M, Untersteller E. J Am Chem Soc 1995;117:1173. (h) Nicolaou KC, Hwang C-K, Duggan ME, Nugiel DA, Abe Y, Bal Reddy K, DeFrees SA, Reddy DR, Awartani RA, Conley SR, Rutjes FPJT, Theodorakis EA. J Am Chem Soc 1995;117:10227. (i) Nicolaou KC, Theodorakis EA, Rutjes FPJT, Sato M, Tiebes J, Xiao XY, Hwang CK, Duggan ME, Yang Z, Couladouros EA, Sato F, Shin J, He HM, Bleckman T. J Am Chem Soc 1995;117:10239. (j) Nicolaou KC, Rutjes FPJT, Theodorakis EA, Tiebes J, Sato M, Untersteller E. J Am Chem Soc 1995;117:10252. (k) Nicolaou KC. Angew Chem, Int Ed Engl 1996;35:589.

95. (a) Nicolaou KC, Reddy KR, Skokotas G, Sato F, Xiao XY. J Am Chem Soc 1992;114:7935. (b) Nicolaou KC, Reddy KR, Skokotas G, Sato F, Xiao X-Y, Hwang C-K. J Am Chem Soc 1993;115:3558.

96. (a) Nicolaou KC, McGarry DG, Somers PK. J Am Chem Soc 1990;112:3696. (b) Nicolaou KC, Prasad CVC, Ogilvie WW. J Am Chem Soc 1990;112:4988. (c) Nicolaou KC, Yang Z, Shi GQ, Gunzner JL, Agrios KA, Gärtner P. Nature 1998;392:264. [PubMed: 9521320] (d) Nicolaou KC, Bunnage ME, McGarry DG, Shi S, Somers PK, Wallace PA, Chu X-J, Agrios KA, Gunzner JG, Yang Z. Chem Eur J 1999;5:599. (e) Nicolaou KC, Wallace PA, Shi S, Ouellette MA, Bunnage ME, Gunzner JL, Agrios KA, Shi G-Q, Gärtner P, Yang Z. Chem Eur J 1999;5:618. (f) Nicolaou KC, Shi G-Q, Gunzner JL, Gärtner P, Wallace PA, Ouellette MA, Shi S, Bunnage ME, Agrios KA, Veale CA, Hwang C-K, Hutchinson J, Prasad CVC, Ogilvie WW, Yang Z. Chem Eur J 1999;5:628. (g) Nicolaou KC, Gunzner JL, Shi G-Q, Agrios KA, Gärtner P, Yang Z. Chem Eur J 1999;5:646.

97. (a) Kadota I, Jung-Youl P, Koumura N, Pollaud G, Matsukawa Y, Yamamoto Y. Tetrahedron Lett 1995;36:5777. (b) Kadota I, Yamamota Y. J Org Chem 1998;63:6597. (c) Kadota I, Abe T, Ishitsuka Y, Touchy AS, Nagata R, Yamamota Y. Tetrahedron Lett 2007;48:219.

98. (a) Nakata T, Nomura S, Matsukura H. Tetrahedron Lett 1996;37:213. (b) Nakata T, Nomura S, Matsukura H, Morimoto M. Tetrahedron Lett 1996;37:217. (c) Morimoto M, Matsukura H, Nakata T. Tetrahedron Lett 1996;37:6365.

99. (a) Mori Y, Yaegashi K, Furukawa H. J Am Chem Soc 1997;119:4557. (b) Mori Y, Yaegashi K, Furukawa H. J Org Chem 1998;63:6200. [PubMed: 11672250]

100. (a) Rainer JD, Allwein SP. J Org Chem 1998;63:5310. (b) Rainer JD, Allwein SP. Tetrahedron Lett 1998;39:9601. (c) Rainier JD, Allwein SP, Cox JM. Org Lett 2000;2:231. [PubMed: 10814289] (d) Rainier JD, Allwein SP, Cox JM. J Org Chem 2001;66:1380. [PubMed: 11312970]

101. (a) Holland JM, Lewis M, Nelson A. Angew Chem Int Ed 2001;40:4082. (b) Holland JM, Lewis M, Nelson A. J Org Chem 2003;68:747. [PubMed: 12558395]

102. Zakarian A, Batch A, Holton RA. J Am Chem Soc 2003;125:7822. [PubMed: 12822999]

103. Fujiwara K, Sato D, Watanabe M, Morishita H, Murai A, Kawai H, Suzuki T. Tetrahedron Lett 2004;45:5243.

104. (a) Oishi T, Uehara H, Nagumo Y, Shoji M, Le Brazidec J-Y, Kosaka M, Hirama M. Chem Commun 2001:381. (b) Imai H, Uehara H, Inoue M, Oguri H, Oishi T, Hirama M. Tetrahedron Lett 2001;42:6219. (c) Hirama M, Oishi T, Uehara H, Inoue M, Maruyama M, Oguri H, Satake M. Science 2001;294:1904. [PubMed: 11729311] (d) Maruyama M, Inoue M, Oishi T, Oguri H, Ogasawara Y, Shindo Y, Hirama M. Tetrahedron 2002;58:1835. (e) Inoue M, Uehara H, Maruyama M, Hirama M. Org Lett 2002;4:4551. [PubMed: 12465935] (f) Uehara H, Oishi T, Inoue M, Shoji M, Nagumo Y, Kosaka M, Le Brazidec JY, Hirama M. Tetrahedron 2002;58:6493. (g) Tatami A, Inoue M, Uehara H, Hirama M. Tetrahedron Lett 2003;44:5229. (h) Oguri H, Hirama M, Tsumuraya T, Fujii I, Maruyama M, Uehara H, Nagumo Y. J Am Chem Soc 2003;125:7608. [PubMed: 12812503] (i) Inoue M, Yamashita S, Tatami A, Miyazaki K, Hirama M. J Org Chem 2004;69:2797. [PubMed: 15074930] (j) Inoue M, Hirama M. Acc Chem Res 2004;37:961. [PubMed: 15609988] (k) Inoue M, Hirama M. Synlett 2004;4:577. (l) Inoue M, Miyazaki K, Uehara H, Maruyama M, Hirama M. Proc Natl Acad Sci USA 2004;101:12013. [PubMed: 15199182]

105. (a) Fuwa H, Sasaki M, Tachibana K. Tetrahedron Lett 2000;41:8371. (b) Fuwa H, Sasaki M, Tachibana K. Tetrahedron 2001;57:3019. (c) Fuwa H, Sasaki M, Tachibana K. Org Lett 2001;3:3549. [PubMed: 11678705] (d) Fuwa H, Kainuma N, Tachibana K, Sasaki M. J Am Chem Soc 2002;124:14983. [PubMed: 12475341]

106. (a) Kadota I, Park C-H, Ohtaka M, Oguro N, Yamamoto Y. Tetrahedron Lett 1998;39:6365. (b) Kadota I, Kadowaki C, Yoshida N, Yamamoto Y. Tetrahedron Lett 1998;39:6369. (c) Kadota I, 
Ohno A, Matsukura Y, Yamamoto Y. Tetrahedron Lett 1998;39:6373. (d) Kadota I, Ohno A, Matsuda K, Yamamoto Y. J Am Chem Soc 2001;123:6702. [PubMed: 11439061] (e) Kadota I, Kadowaki C, Park CH, Takamura H, Sato K, Chan PWH, Thorand S, Yamamoto Y. Tetrahedron 2002;58:1799. (f) Kadota I, Takamura H, Sato K, Yamamoto Y. J Org Chem 2002;67:3494. [PubMed: 12003565] (g) Kadota I, Ohno A, Matsuda K, Yamamoto Y. J Am Chem Soc 2002;124:3562. [PubMed: 11929244] (h) Kadota I, Takamura H, Sato K, Ohno A, Matsuda K, Yamamoto Y. J Am Chem Soc 2003;125:46. [PubMed: 12515504] (i) Kadota I, Takamura H, Sato K, Ohno A, Matsuda K, Satake M, Yamamoto Y. J Am Chem Soc 2003;125:11893. [PubMed: 14505411]

107. (a) Cox JM, Rainer JD. Org Lett 2001;3:2919. [PubMed: 11529790] (b) Majumder U, Cox JM, Rainier JD. Org Lett 2003;5:913. [PubMed: 12633104] (c) Johnson HWB, Majumder U, Rainer JD. J Am Chem Soc 2005;127:848. [PubMed: 15656618] (d) Majumder U, Cox JM, Johnson HWB, Rainier JD. Chem Eur J 2006;12:1747. (e) Johnson HWB, Majumder U, Rainier JD. Chem Eur J 2006; $12: 1736$.

108. (a) Sasaki M, Tsukano C, Tachibana K. Org Lett 2002;4:1747. [PubMed: 12000289] (b) Sasaki M, Tsukano C, Tachibana K. Tetrahedron Lett 2003;44:4351. (c) Tsukano C, Sasaki M. J Am Chem Soc 2003;125:14294. [PubMed: 14624575] (d) Tsukano C, Ebine M, Sasaki M. J Am Chem Soc 2005;127:4326. [PubMed: 15783214] (e) Tsukano C, Sasaki M. Tetrahedron Lett 2006;47:6803.

109. (a) Matsuo G, Matsukura H, Hori N, Nakata T. Tetrahedron Lett 2000;41:7673. (b) Matsuo G, Hori N, Matsukura H, Nakata T. Tetrahedron Lett 2000;41:7677. (c) Matsukura H, Hori N, Matsuo G, Nakata T. Tetrahedron Lett 2000;41:7681. (d) Matsuo G, Kawamura K, Hori N, Matsukura H, Nakata T. J Am Chem Soc 2004;126:14374. [PubMed: 15521755]

110. (a) Fuwa H, Ebine M, Sasaki M. J Am Chem Soc 2006;128:9648. [PubMed: 16866516] (b) Fuwa H, Ebine M, Bourdelais AJ, Baden DG, Sasaki M. J Am Chem Soc 2006;128:16989. [PubMed: 17177450]

111. (a) Yokoyama A, Murata M, Oshima Y, Iwashita T, Yasumoto T. J Biochem 1988;104:184. [PubMed: 3182760] (b) Murata M, Iwashita T, Yokoyama A, Sasaki M, Yasumoto T. J Am Chem Soc 1992;114:6594. (c) Murata M, Naoki H, Iwashita T, Matusunaga S, Sasaki M, Yokoyama A, Yasumoto T. J Am Chem Soc 1993;115:2060. (d) Murata M, Naoki H, Matsunaga S, Satake M, Yasumoto T. J Am Chem Soc 1994;116:7098. (e) Satake M, Ishida S, Yasumoto T, Murata M, Utsumi H, Hinomoto T. J Am Chem Soc 1995;117:7019. (f) Matsumori N, Kaneno D, Murata M, Nakamura H, Tachibana K. J Org Chem 1999;64:866. [PubMed: 11674159]

112. (a) Sasaki M, Matsumori N, Maruyama T, Nonomura T, Murata M, Tachibana K, Yasumoto T. Angew Chem Int Ed Engl 1996;35:1672. (b) Matsumori N, Nonomura T, Sasaki M, Murata M, Tachibana K, Satake M, Yasumoto T. Tetrahedron Lett 1996;37:1269. (c) Sasaki M, Matsumori N, Murata M, Tachibana K, Yasumoto T. Tetrahedron Lett 1995;36:9011. (d) Sasaki M, Nonomura T, Murata M, Tachibana K. Tetrahedron Lett 1994;35:5023. (e) Sasaki M, Nonomura T, Murata M, Tachibana K. Tetrahedron Lett 1995;36:9007. (f) Nonomura T, Sasaki M, Matsumori N, Murata M, Tachibana K, Yasumoto T. Angew Chem Int Ed Engl 1996;35:1675.

113. (a) Zheng W, DeMattei JA, Wu J-P, Duan JJ-W, Cook LR, Oinuma H, Kishi Y. J Am Chem Soc 1996;118:7946. (b) Cook LR, Oinuma H, Semones MA, Kishi Y. J Am Chem Soc 1997;119:7928. (c) Kishi Y. Pure Appl Chem 1998;70:339.

114. (a) Armstrong RW, Beau J-M, Cheon SH, Christ WJ, Fujioka H, Ham W-H, Hawkins LD, Jin H, Kang SH, Kishi Y, Martinelli MJ, McWhorter WW Jr, Mizuno M, Nakata M, Stutz AE, Talamas FX, Taniguchi M, Tino JA, Ueda K, Uenishi J, White JB, Yonaga M. J Am Chem Soc 1989;111:7525. (b) Armstrong RW, Beau J-M, Cheon SH, Christ WJ, Fujioka H, Ham W-H, Hawkins LD, Jin H, Kang SH, Kishi Y, Martinelli MJ, McWhorter WW Jr, Mizuno M, Nakata M, Stutz AE, Talamas FX, Taniguchi M, Tino JA, Ueda K, Uenishi J, White JB, Yonaga M. J Am Chem Soc 1989;111:7530. (c) Suh EM, Kishi Y. J Am Chem Soc 1994;116:11205. (d) Kishi Y. Chem Scr 1987;27:573. (e) Kishi Y. Pure Appl Chem 1989;61:313.

115. Gallimore AR, Spencer JB. Angew Chem Int Ed 2006;45:4406.

116. (a) Nicolaou KC, Frederick MO. Angew Chem Int Ed 2007;46:5278. (b) Nicolaou KC, Cole KP, Frederick MO, Aversa RJ, Denton RM. Angew Chem Int Ed 2007;46:8875.

117. (a) Fujii A, Hashiguchi S, Uematsu N, Ikariya T, Noyori R. J Am Chem Soc 1996;118:2521. (b) Noyori R, Hashiguchi S. Acc Chem Res 1997;30:97. 
118. Nicolaou KC, Frederick MO, Burtoloso ACB, Denton RM, Rivas F, Cole KP, Aversa RJ, Gibe R, Umezawa T, Suzuki T. J Am Chem Soc 2008;130:7466. [PubMed: 18481856]

119. Nicolaou KC, Frederick MO, Aversa RJ. Angew Chem Int Ed 2008;47:7182.

120. Hanessian, S. Total Synthesis of Natural Products: The "Chiron" Approach. Vol. 3. Pergamon; Oxford: 1983. Organic Chemistry Series; p. 291 

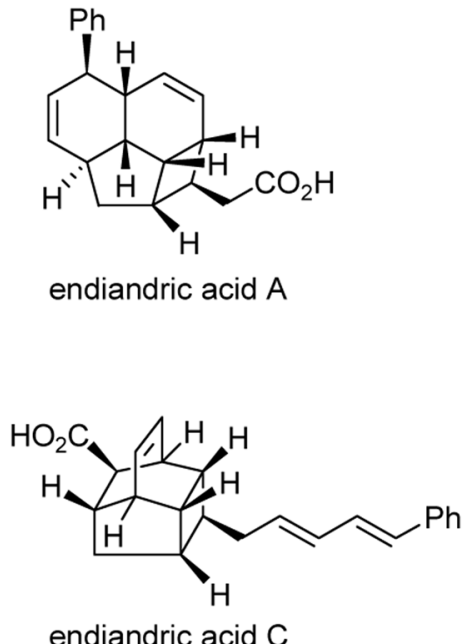

endiandric acid $\mathrm{C}$

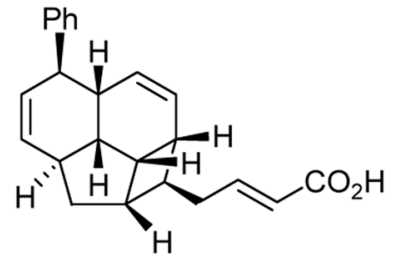

endiandric acid B

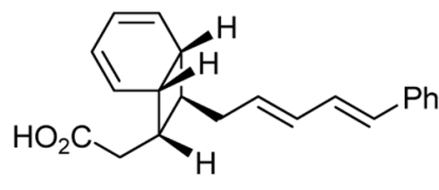

endiandric acid D

FIGURE 1.

Molecular structures of endiandric acids A-D. 
<smiles>O=C(O)/C=C/CC#C/C=C/C=C/c1ccccc1</smiles>

or<smiles>O=C(O)/C=C\C/C=C\C/C=C/C#C/C=C/c1ccccc1</smiles>
conrotatory $8 \pi e$ electrocyclization<smiles>O=C(O)/C=C/CC(c1ccccc1)[C@H](/C=C/c1ccccc1)C/C=C/c1ccccc1</smiles><smiles>O=C([O-])/C=C/[C@@H](C/C=C/c1ccccc1)[C@@H](C/C=C/C(=O)O)c1ccccc1</smiles>
disrotatory $6 \pi e$ electrocyclization

disrotatory $6 \pi e$ electrocyclization<smiles>CC(C=CCC[C@@H]1C=CC=C[C@@H]1CC=CC=Cc1ccccc1)C(=O)O</smiles>

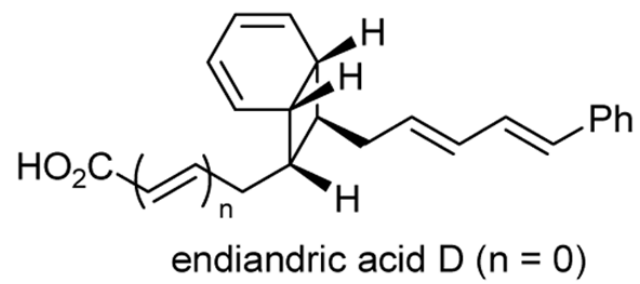

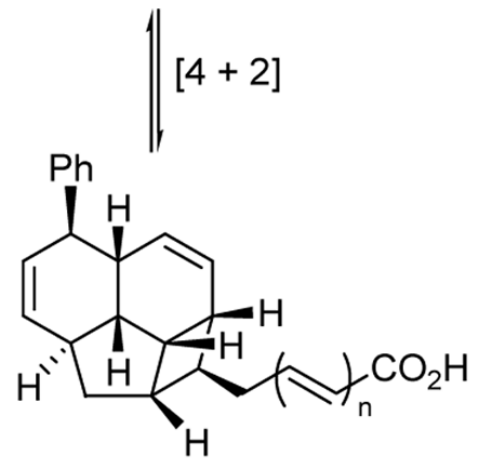

endiandric acid $A(n=0)$ endiandric acid $B(n=1)$

$$
[4+2] \|(n=1)
$$

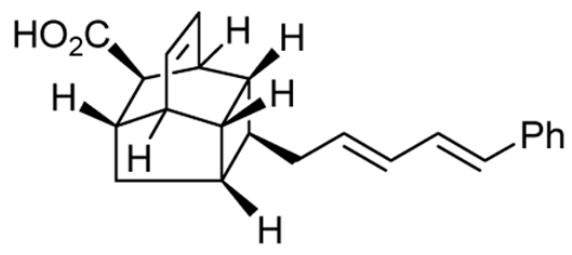

endiandric acid C

FIGURE 2.

The Black hypothesis for the biosynthesis of the endiandric acids (St. C. Black et al., 1980). ${ }^{4}$ 


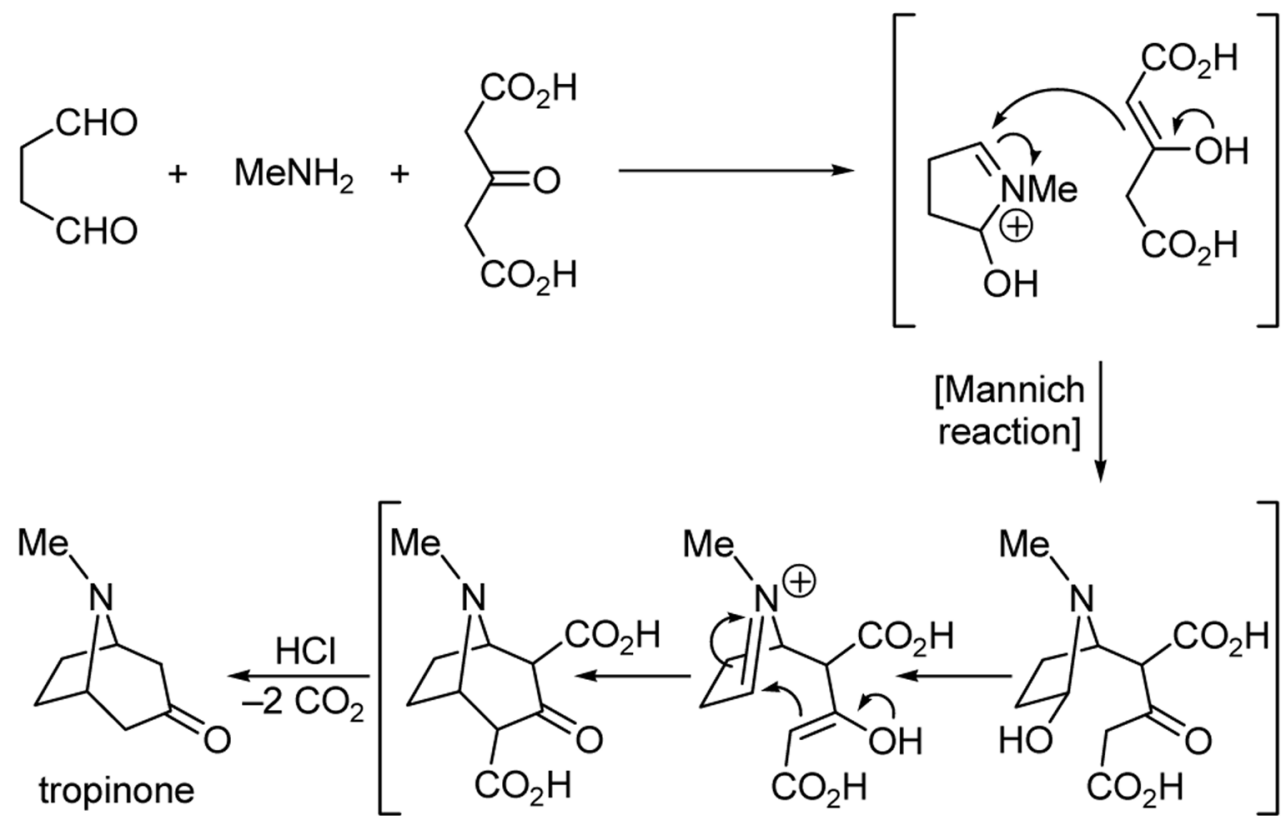

FIGURE 3.

Biomimetic total synthesis of tropinone (Robinson, 1917). ${ }^{8}$ 
<smiles>CC#CCC/C=C(\C)CC/C=C/CC1=C(C)CCC1(C)O</smiles><smiles>CC(C)C1COC(=O)O1</smiles><smiles>CC(=O)[C@H]1CC[C@H]2[C@@H]3CCC4=CC(=O)CC[C@]4(C)[C@H]3CC[C@]12C</smiles>

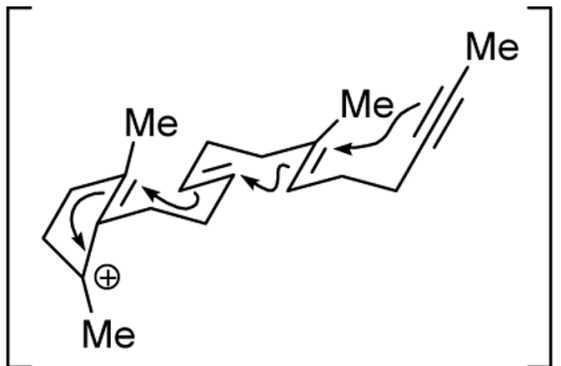
then aq. $\mathrm{K}_{2} \mathrm{CO}_{3}$

FIGURE 4.

Biomimetic total synthesis of progesterone (Johnson et al., 1971). ${ }^{9}$ 

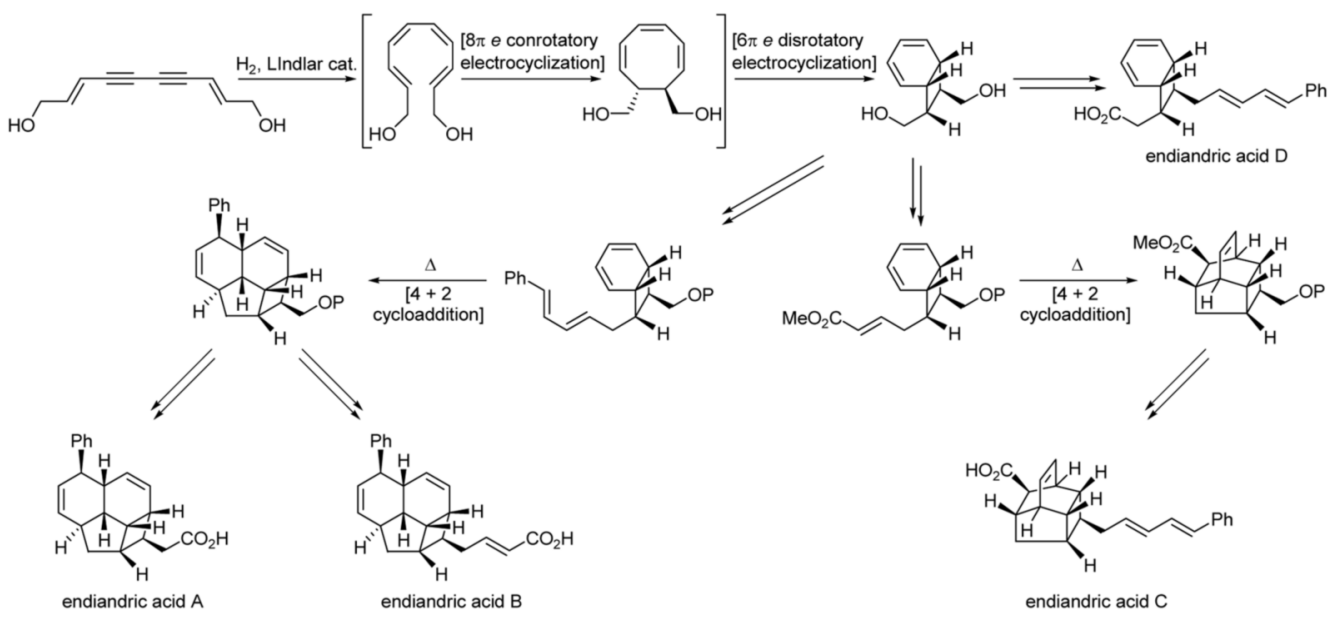

FIGURE 5.

Stepwise total synthesis of endiandric acids A-D (Nicolaou et al., 1982). ${ }^{11}$ 

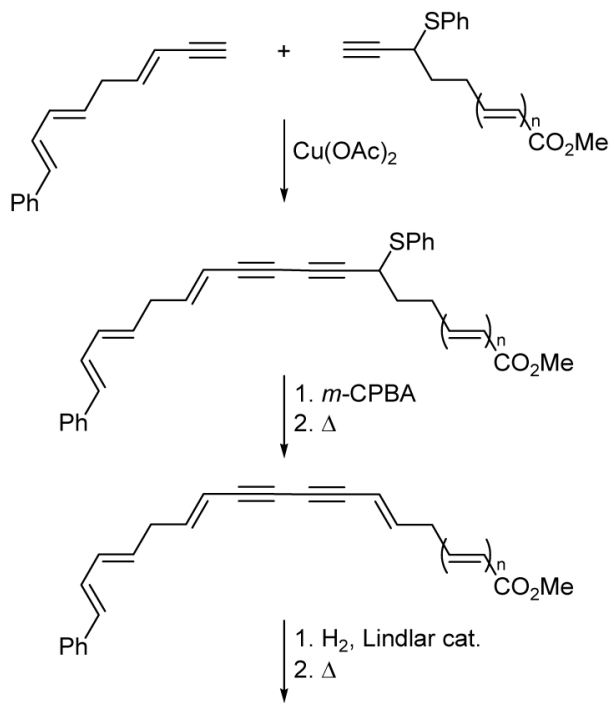

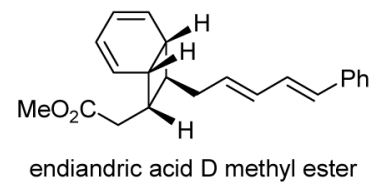

(before heating)

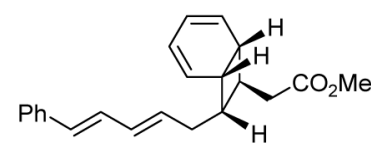

endiandric acid $\mathrm{E}$ methyl ester (before heating)

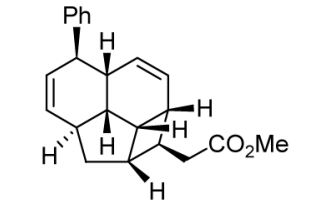

endiandric acid $A$ methyl ester

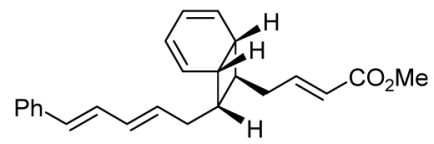

endiandric acid $\mathrm{F}$ methyl ester (before heating)

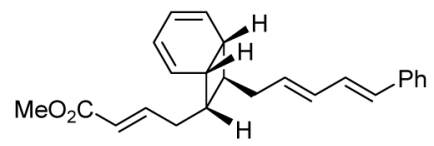

endiandric acid $G$ methyl ester (before heating)

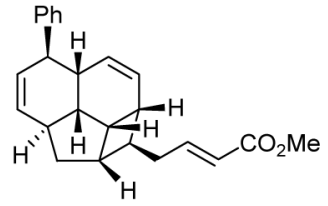

endiandric acid $B$ methyl ester

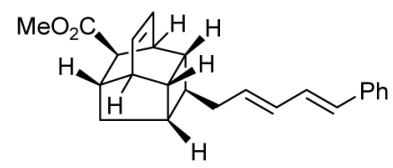

endiandric acid $\mathrm{C}$ methyl ester

FIGURE 6.

Cascade total synthesis of endiandric acids A-G (Nicolaou et al., 1982). ${ }^{12}$ 

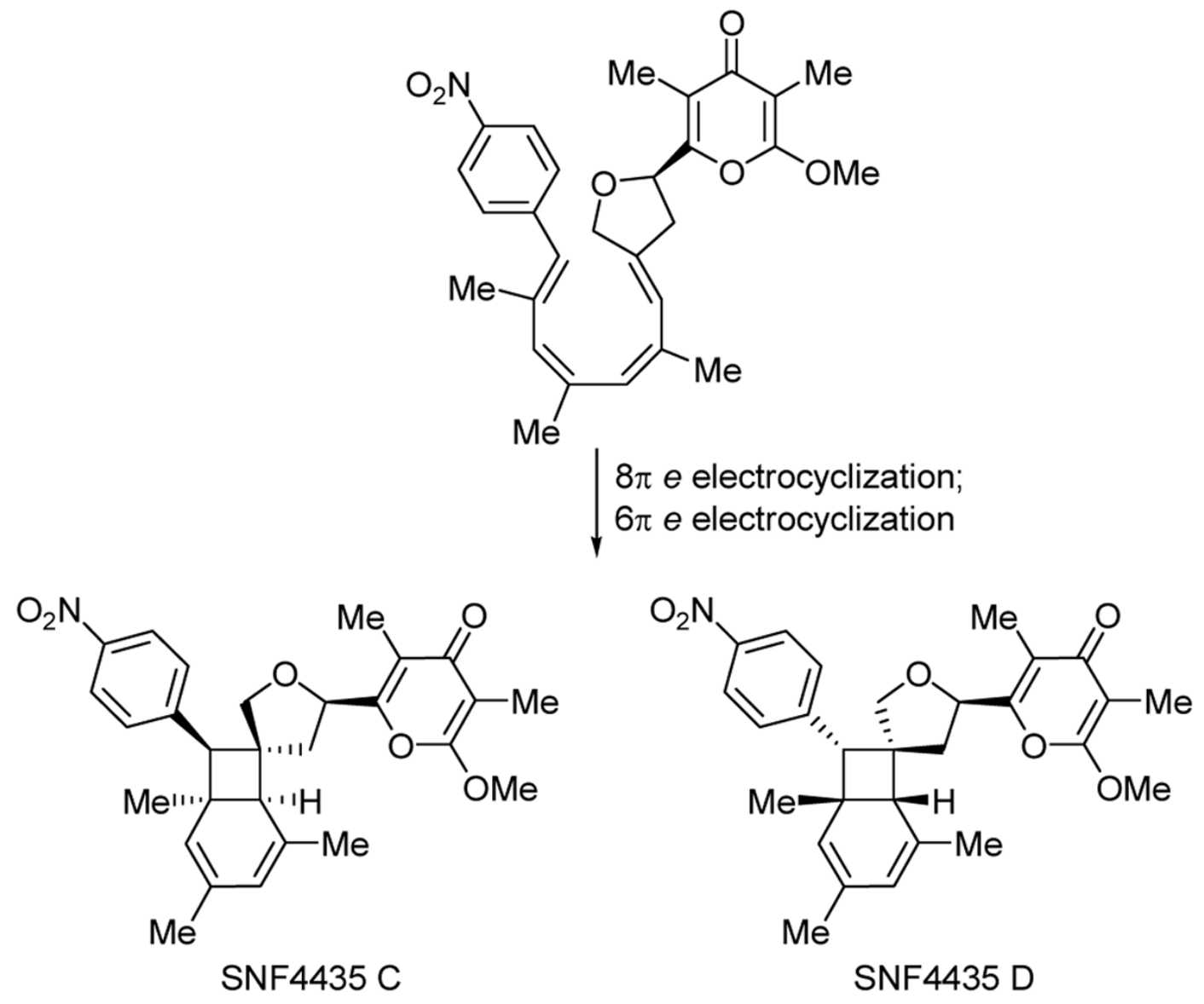

FIGURE 7.

Total synthesis of SNF4435 C and D based on the endiandric acid cascade (Parker and Lim, 2004: ${ }^{14}$ Baldwin et al., 2005; ${ }^{15}$ Beaudry and Trauner, 2005 ${ }^{16}$ ). 


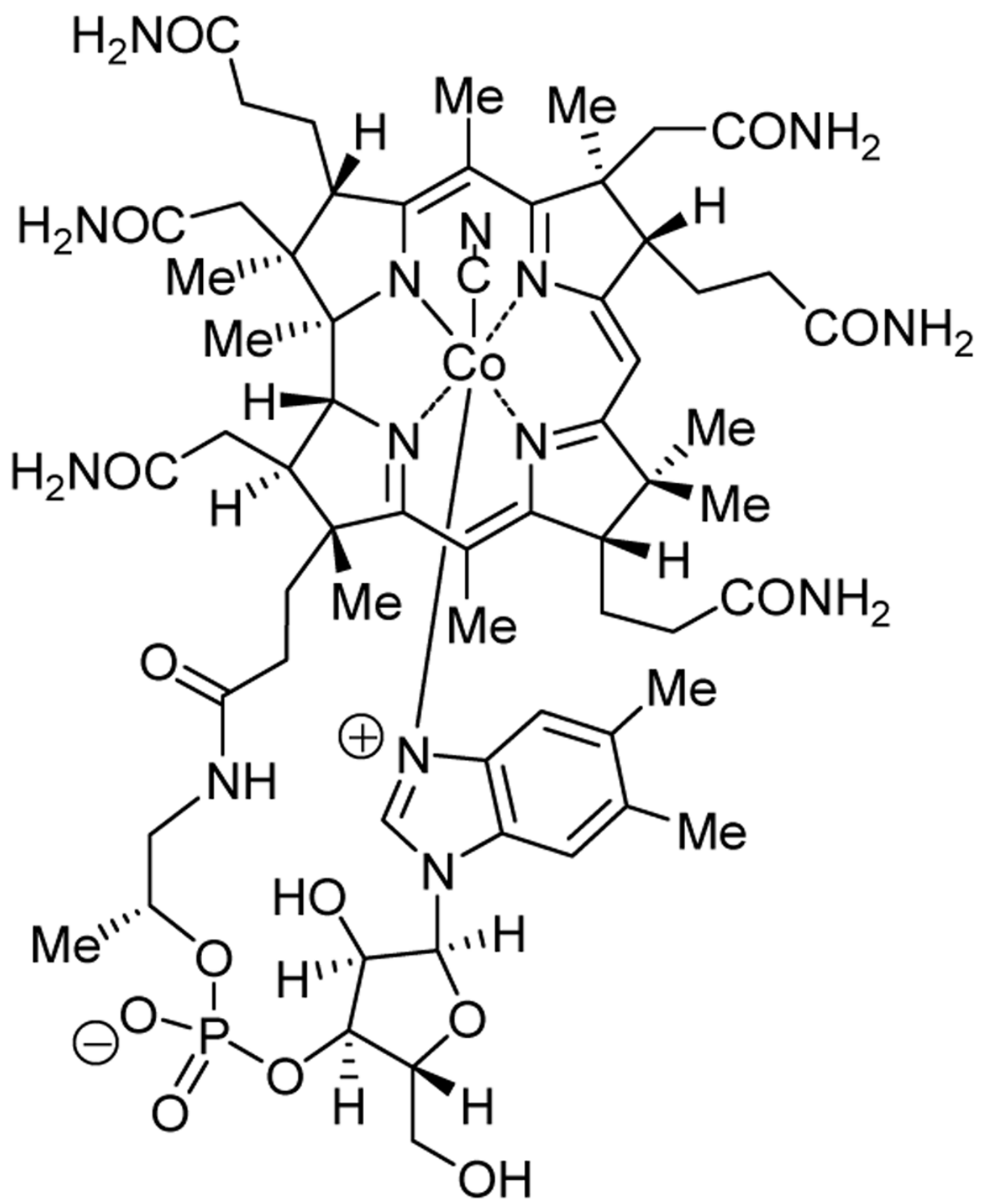

FIGURE 8.

Molecular structure of vitamin $B_{12}$. 
(a) Originally proposed (erroneous) structure of calicheamicin $\gamma_{1}{ }^{\prime}$.

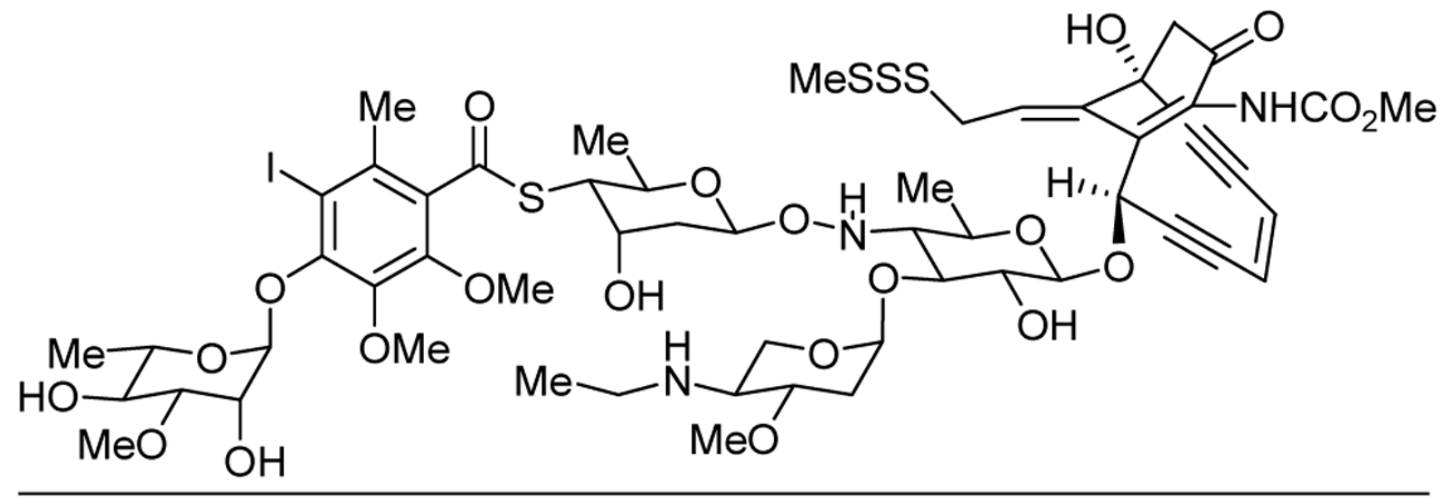

(b) Revised (correct) structure of calicheamicin $\gamma_{1}$.

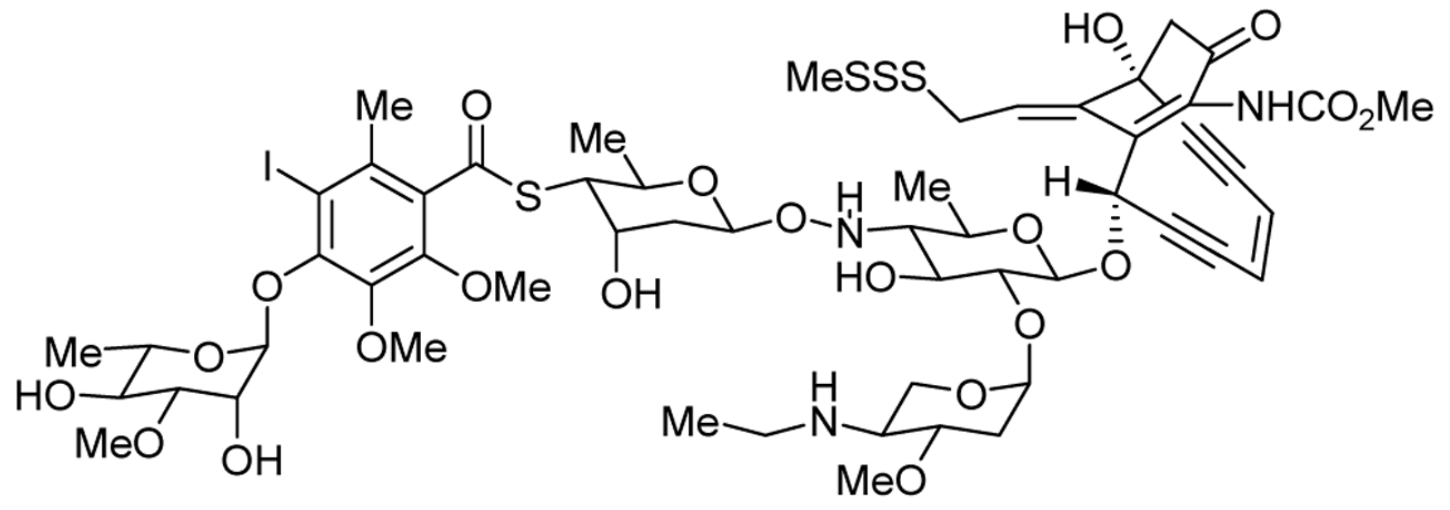
calicheamicin $\gamma_{1}{ }^{\prime}$

FIGURE 9.

Originally proposed and revised molecular structure of calicheamicin $\gamma_{1} \mathrm{I}$. 


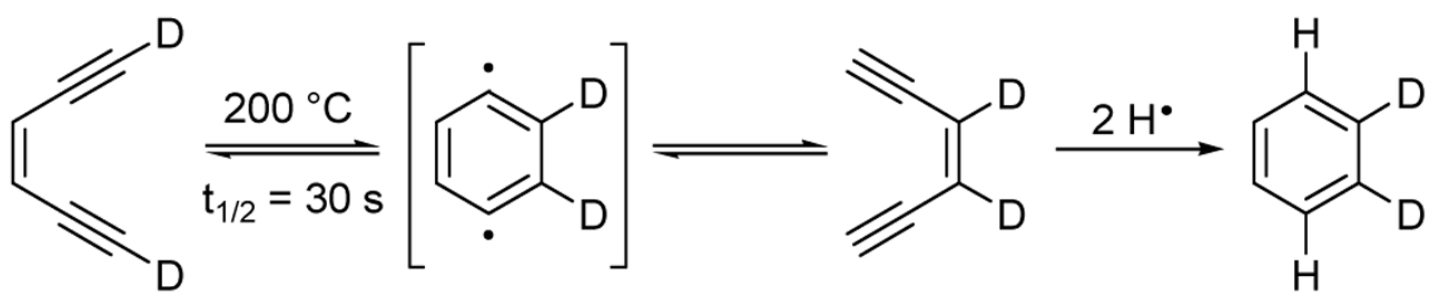

FIGURE 10.

Bergman cycloaromatization reaction (Jones and Bergman, 1972). ${ }^{32}$ 

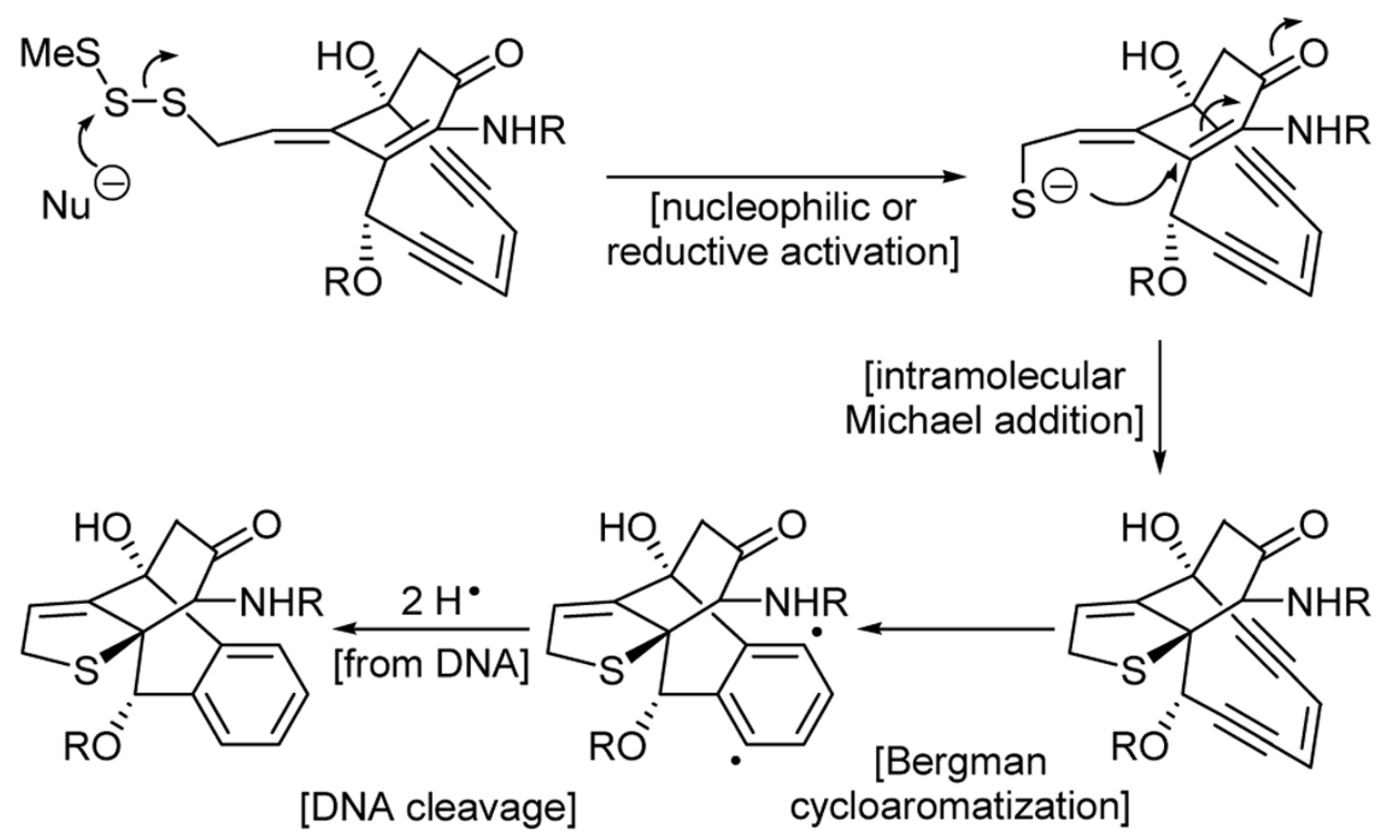

FIGURE 11.

Mechanism of action of calicheamicin $\gamma_{1}{ }^{\mathrm{I}}$. 
(a) Highlights of the total synthesis of the calicheamicin $\gamma_{1}^{\prime}$ oligosaccharide domain.

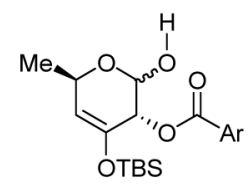

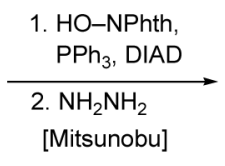

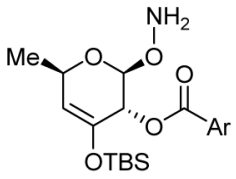

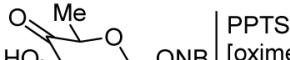
HO工 ONB [oxime OSugar formation]
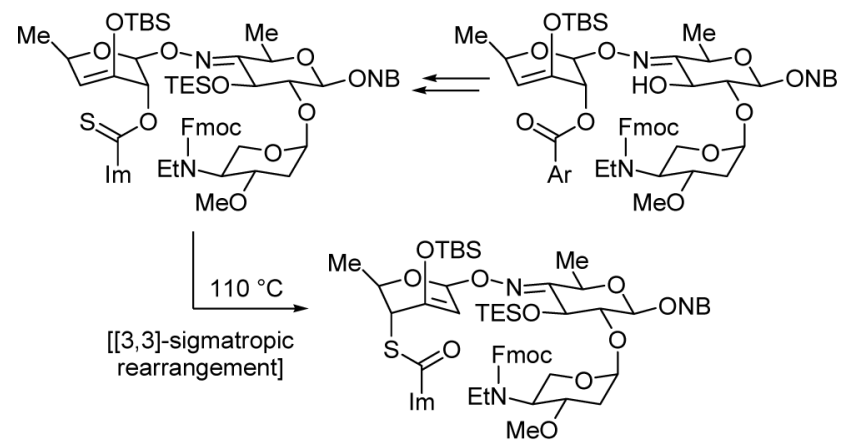

(b) Highlights of the total synthesis of calicheamicinone and calicheamicin $\gamma_{1}$.
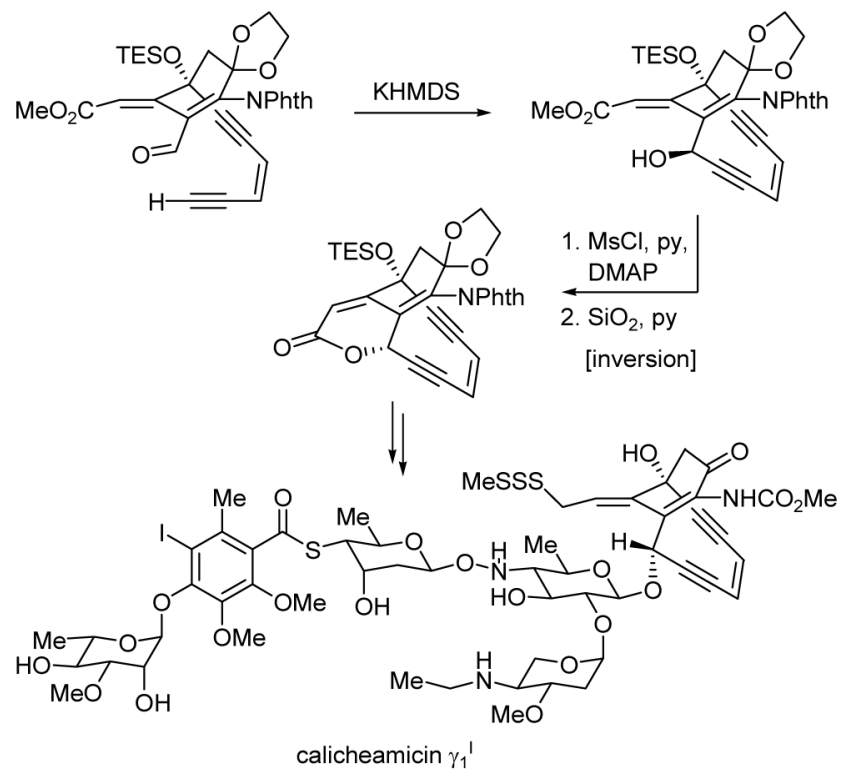

FIGURE 12

Highlights of the total synthesis of calicheamicin $\gamma_{1}{ }^{\mathrm{I}}$ (Nicolaou et al., 1992). ${ }^{35}$ 


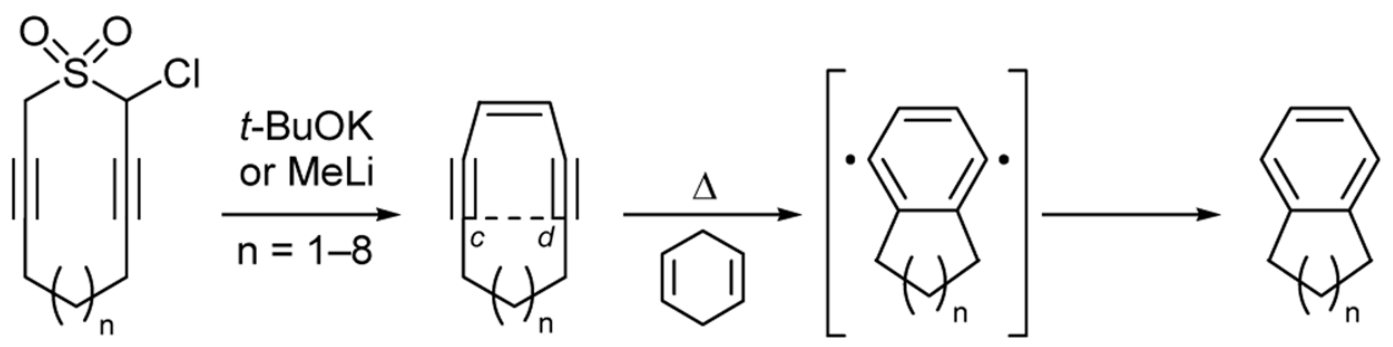

FIGURE 13.

Synthesis and study of cyclic enediynes (Nicolaou et al., 1988). 36 

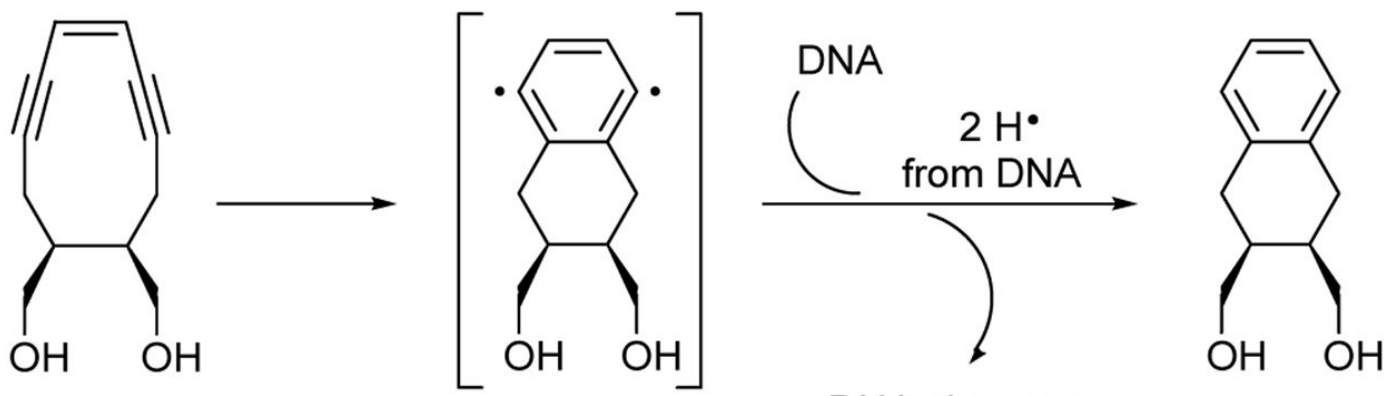

DNA cleavage

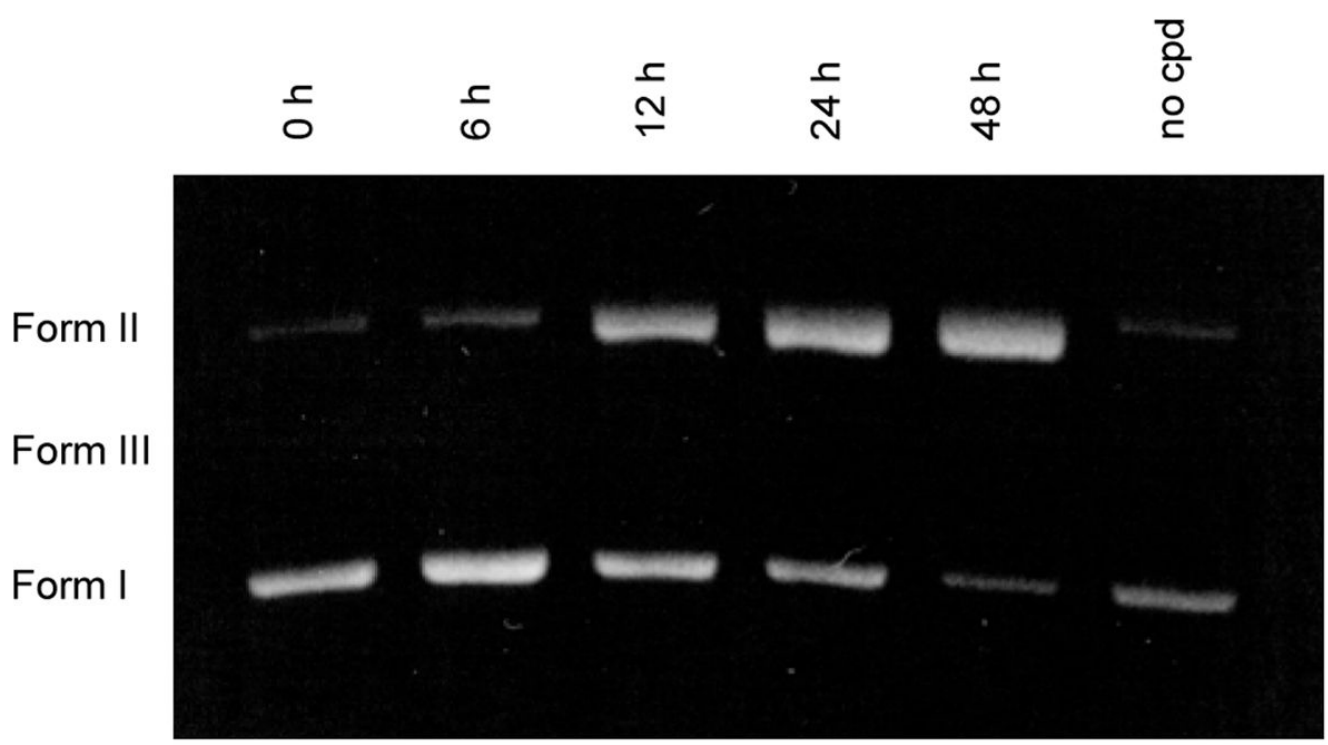

FIGURE 14.

Electrophoresis gel showing $\Phi$ X174 DNA cleavage by a designed enediyne. Forms I, II, and III refer to supercoiled, relaxed circular, and linear DNA, respectively (Nicolaou et al., 1988). 36 (Photo reprinted with permission from J. Am. Chem. Soc., Vol. 110, p. 7247. Copyright 1988 American Chemical Society.) 

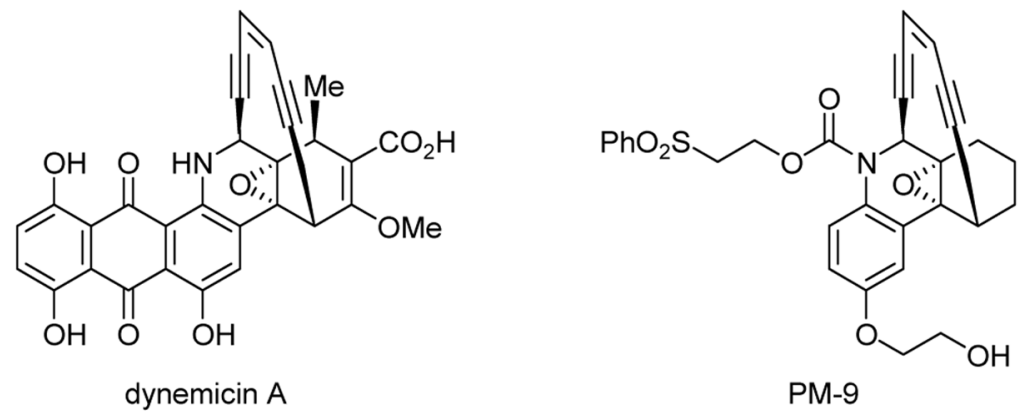

FIGURE 15.

Molecular structures of dynemicin A and PM-9, a designed enediyne with highly potent DNA cleaving and cytotoxic properties (Nicolaou et al., 1990-1992). ${ }^{37}$ 

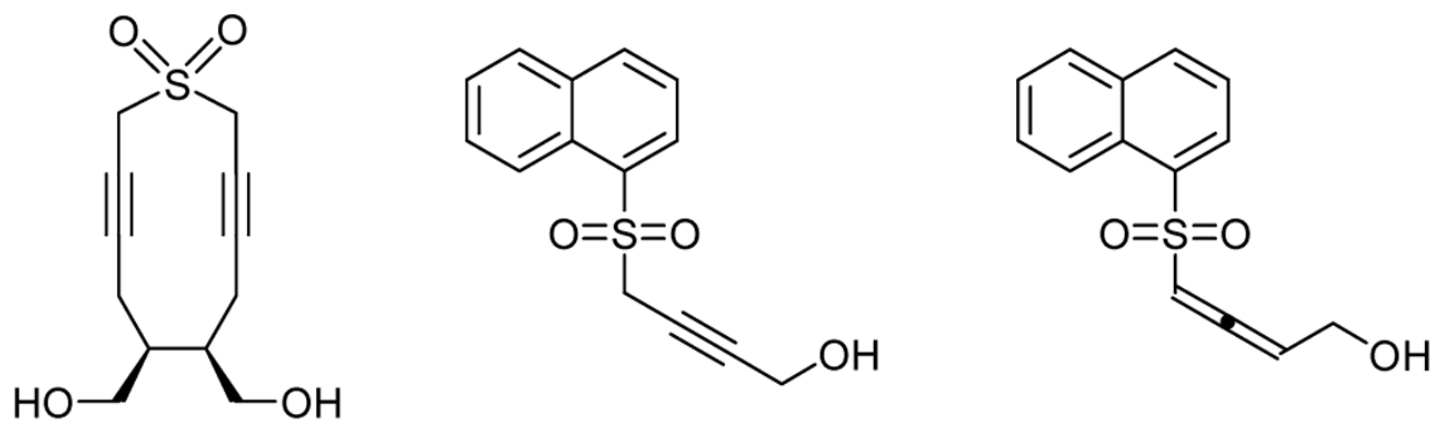

FIGURE 16.

Propargylic and allenic sulfones as DNA cleaving agents (Nicolaou et al., 1989-1991). ${ }^{38}$ 
<smiles>COC(=O)c1c(C)c(I)c(O)c(OC)c1OC</smiles>

$(R, R, R)$<smiles>COC(=O)c1c(C)c(I)c(O)c(OC)c1OC</smiles>

$(S, S, S)$

FIGURE 17.

Spontaneous resolution of a calicheamicin $\gamma_{1}{ }^{\mathrm{I}}$ aromatic fragment into crystals containing enantiomers $[(R, R, R$,$) and (S, S, S)]$ (Nicolaou et al., 1988). ${ }^{41}$ 


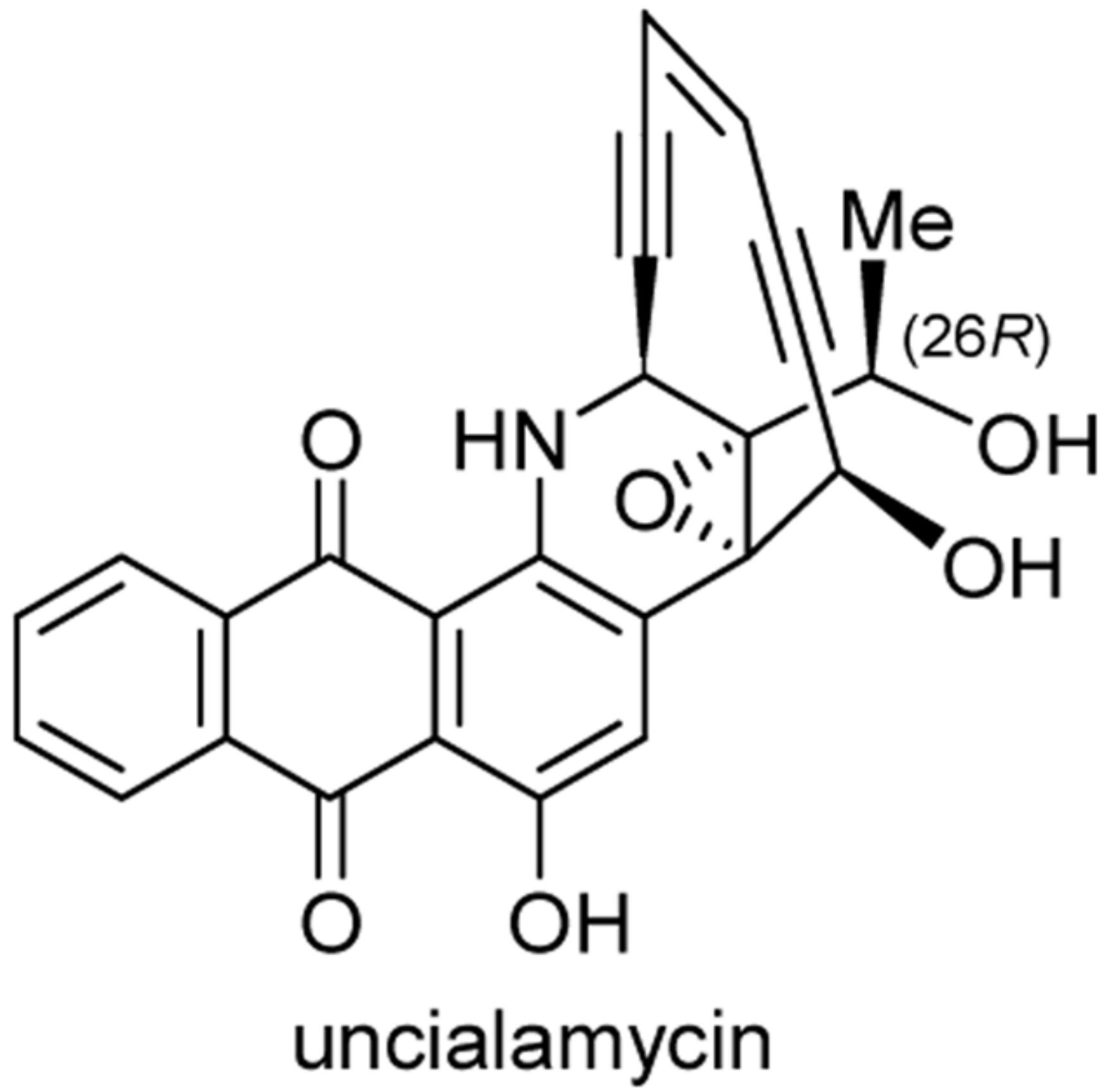

FIGURE 18.

Molecular structure of uncialamycin. 


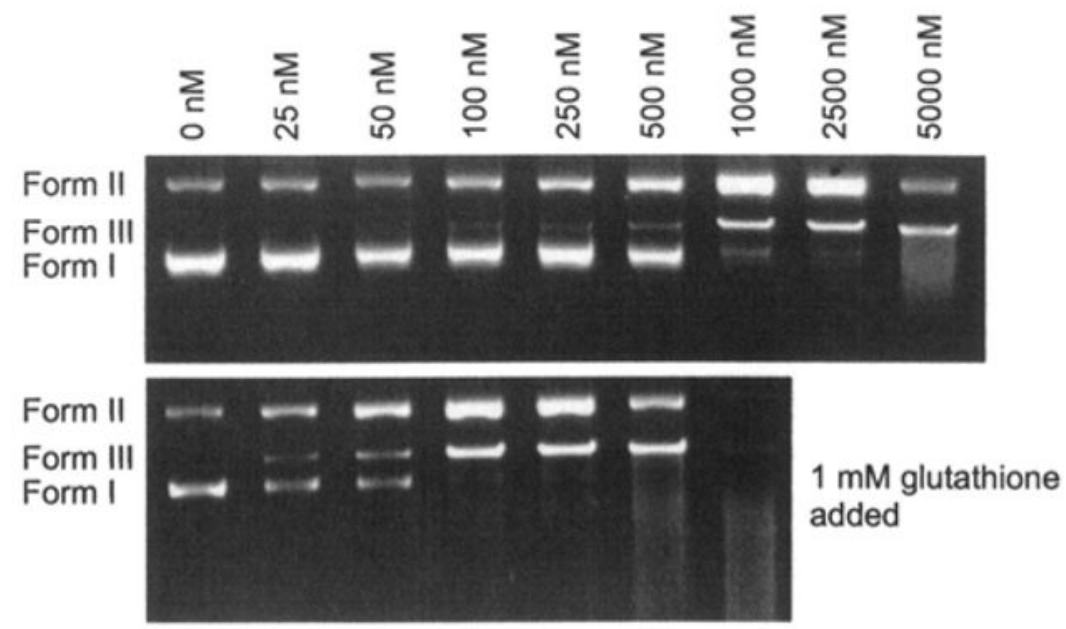

\section{FIGURE 19.}

Electrophoresis gels showing single and double strand cleavage of $\Phi$ X174 DNA by uncialamycin (Nicolaou et al., 2008). ${ }^{53}$ (Photo: K. C. Nicolaou, J. S. Chen, H. Zhang, A. Montero: "Asymmetric Synthesis and Biological Properties of Uncialamycin and 26-epiUncialamycin." Angew. Chem., Int. Ed. 2008, 47, 185-189. Copyright Wiley-VCH Verlag $\mathrm{GmbH} \& \mathrm{Co}$. 


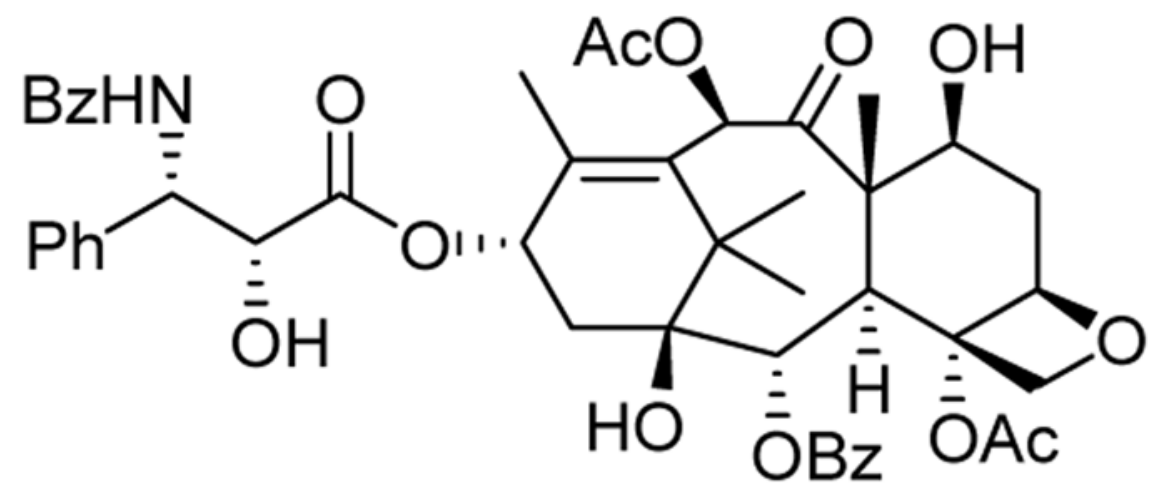

Taxol $^{\circledR}$

FIGURE 20.

Molecular structure of Taxol ${ }^{\circledR}$. 


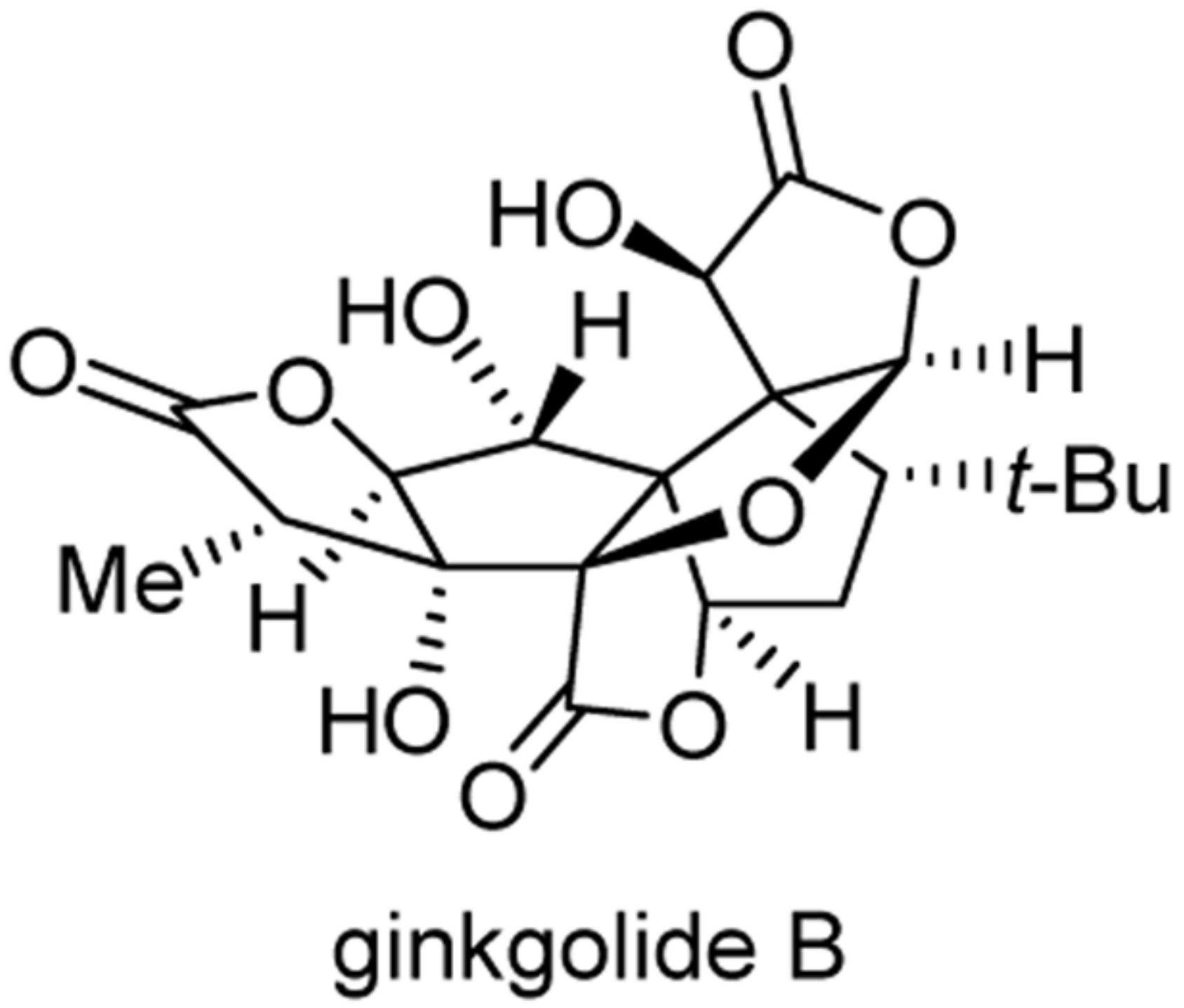

FIGURE 21.

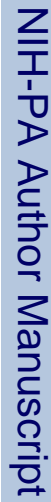

Molecular structure of ginkgolide B. 
<smiles>C=C(C)C(COC(C)=O)=C(C)C</smiles><smiles>C/C=C(/Cl)C#N</smiles><smiles>O=c1occcc1O</smiles><smiles>CCOC(=O)C(C)=CCO</smiles><smiles>C=C=CCOCC1=C(C)CCC(Cl)(C#N)C1(C)C</smiles><smiles>CC(=O)OCC1=C(C)CCC(Cl)(C#N)C1(C)C</smiles>

TPSO

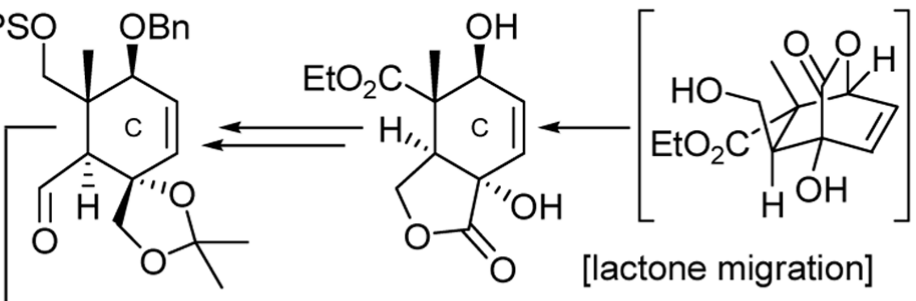
TBSO<smiles>C=C1CCC(C)=C(CC)C1(C)C</smiles>
$\mathrm{NNHSO}_{2} \mathrm{Ar}$

[Shapiro reaction]

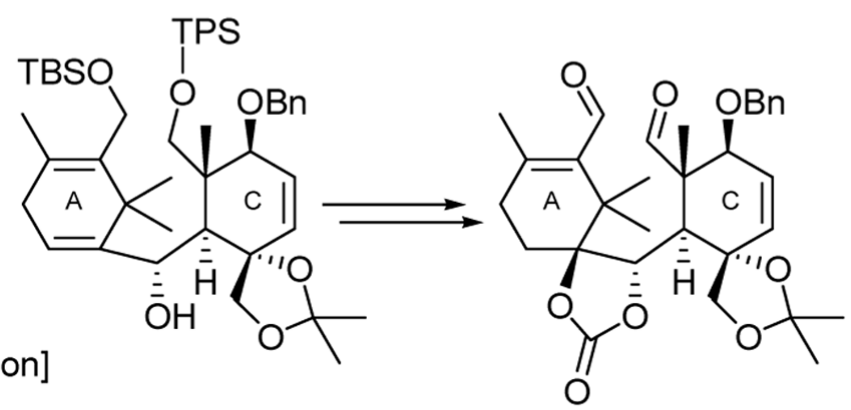
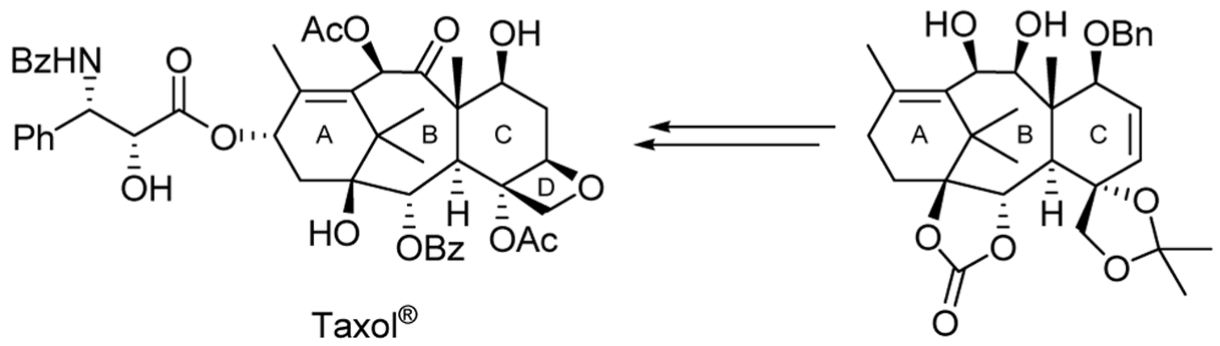

FIGURE 22.

Highlights of the total synthesis of Taxol ${ }^{\circledR}$ (Nicolaou et al., 1994). ${ }^{58}$ 


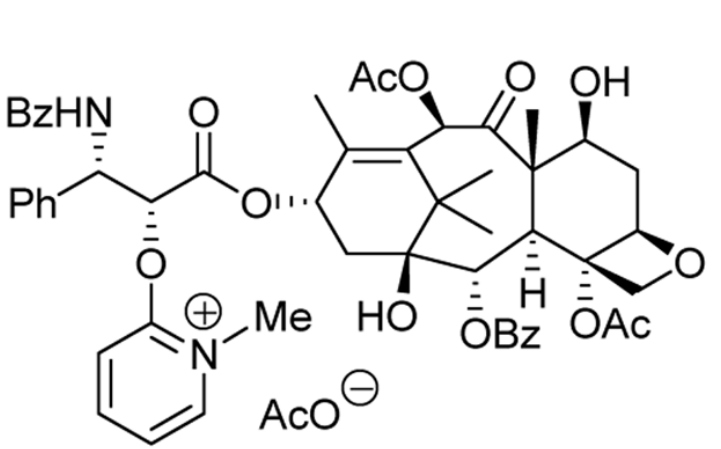

water soluble Taxol ${ }^{\circledR}$ prodrug

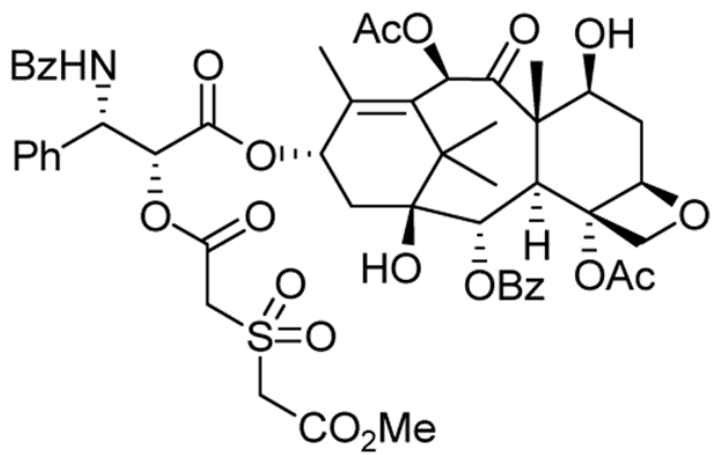

water soluble Taxol ${ }^{\circledR}$ prodrug

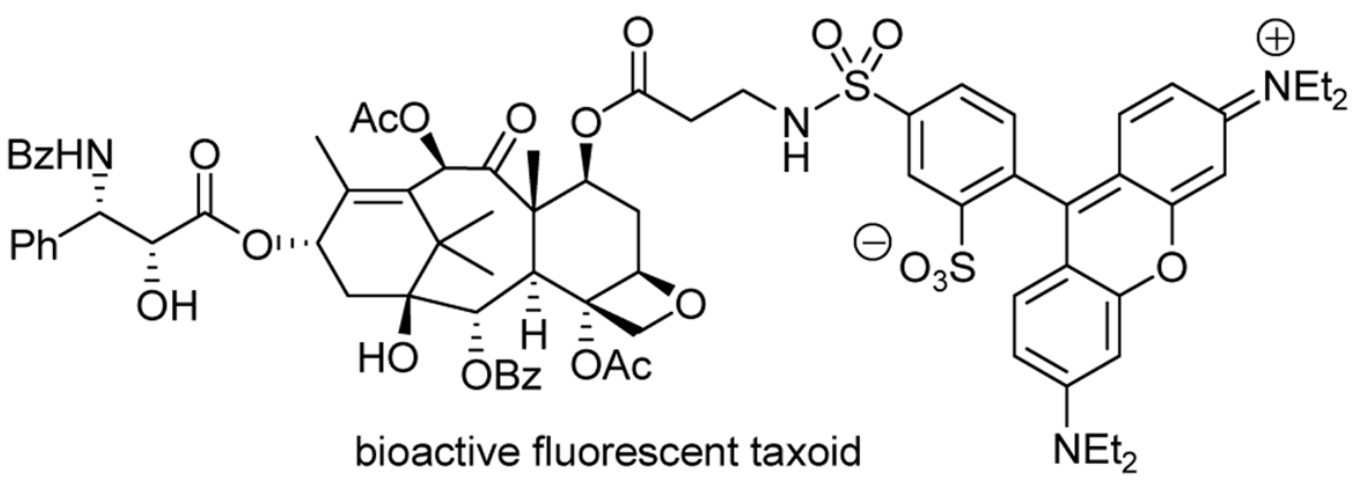

FIGURE 23.

Molecular structures of selected designed analogs synthesized and biologically evaluated during the Taxol ${ }^{\circledR}$ project (Nicolaou et al., 1993-1997). ${ }^{64}$ 


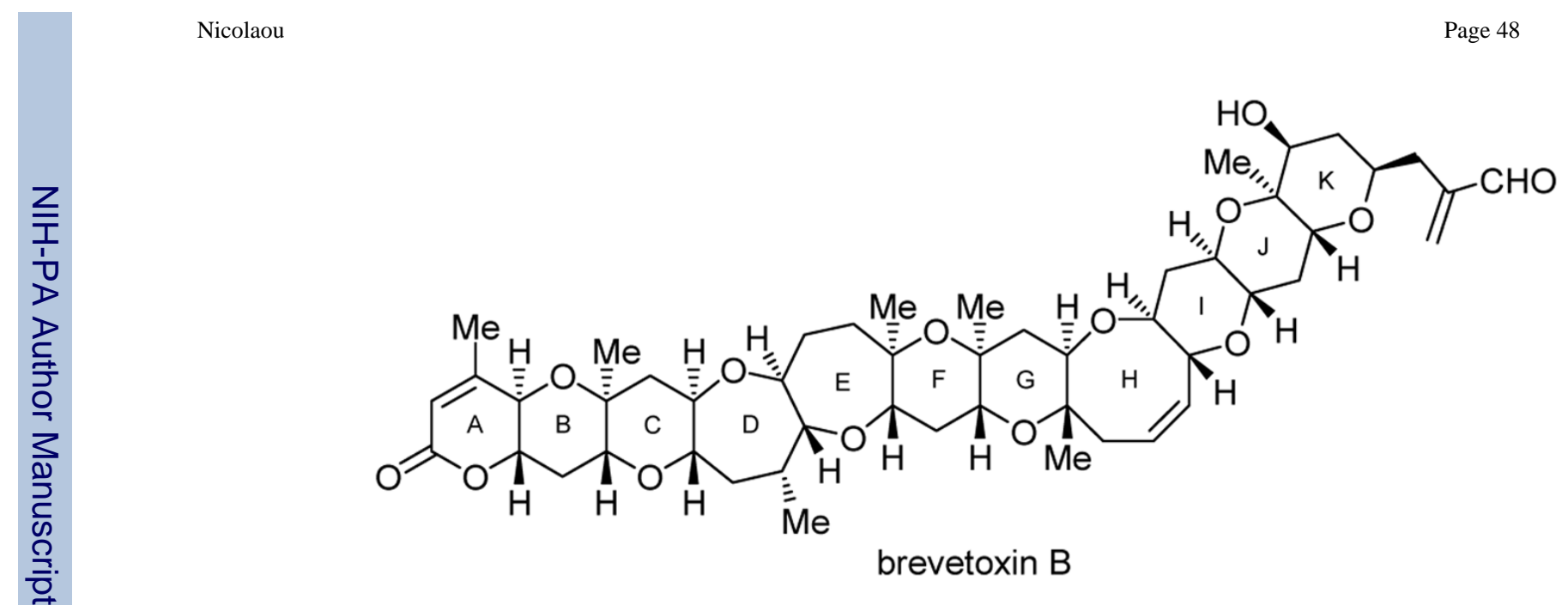

FIGURE 24.

Molecular structure of brevetoxin B. 

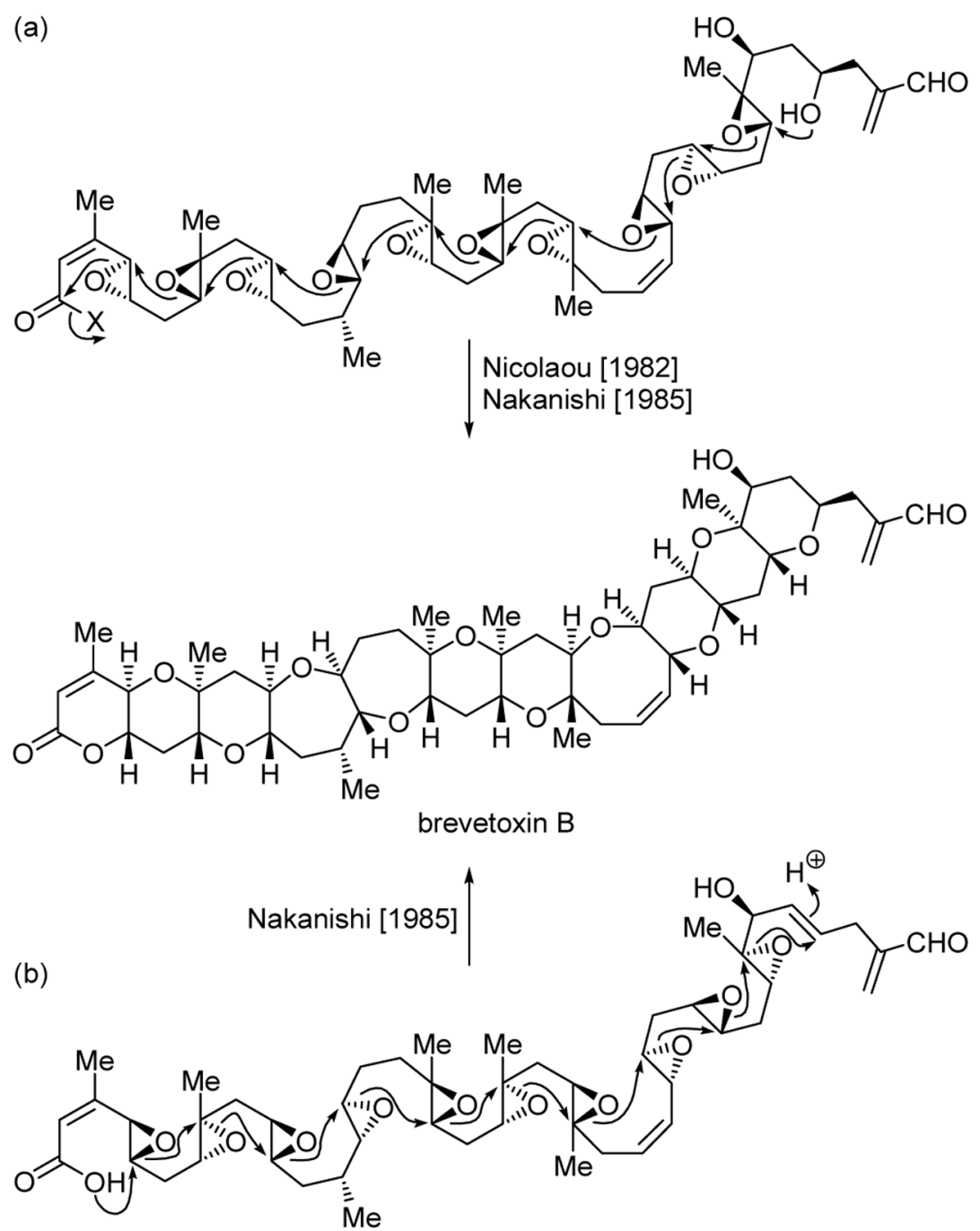

FIGURE 25.

The Nakanishi hypothesis for the biosynthesis of brevetoxin B [(a): Nicolaou, 1982; 73 Nakanishi, $1985 ;{ }^{74}$ (b): Nakanishi, $1985^{74}$ ]. 

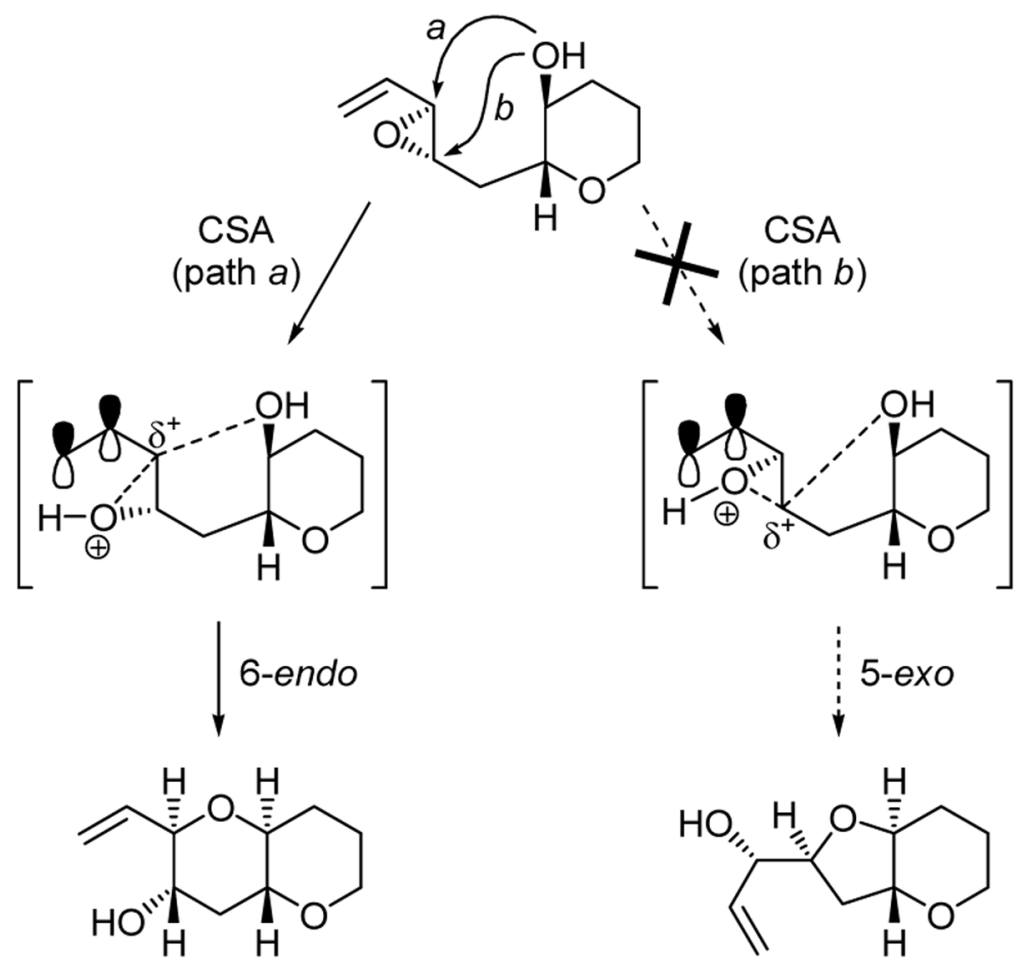

FIGURE 26.

The 6-endo hydroxy epoxide opening method for cyclic ether formation (Nicolaou et al., 1985). 76 

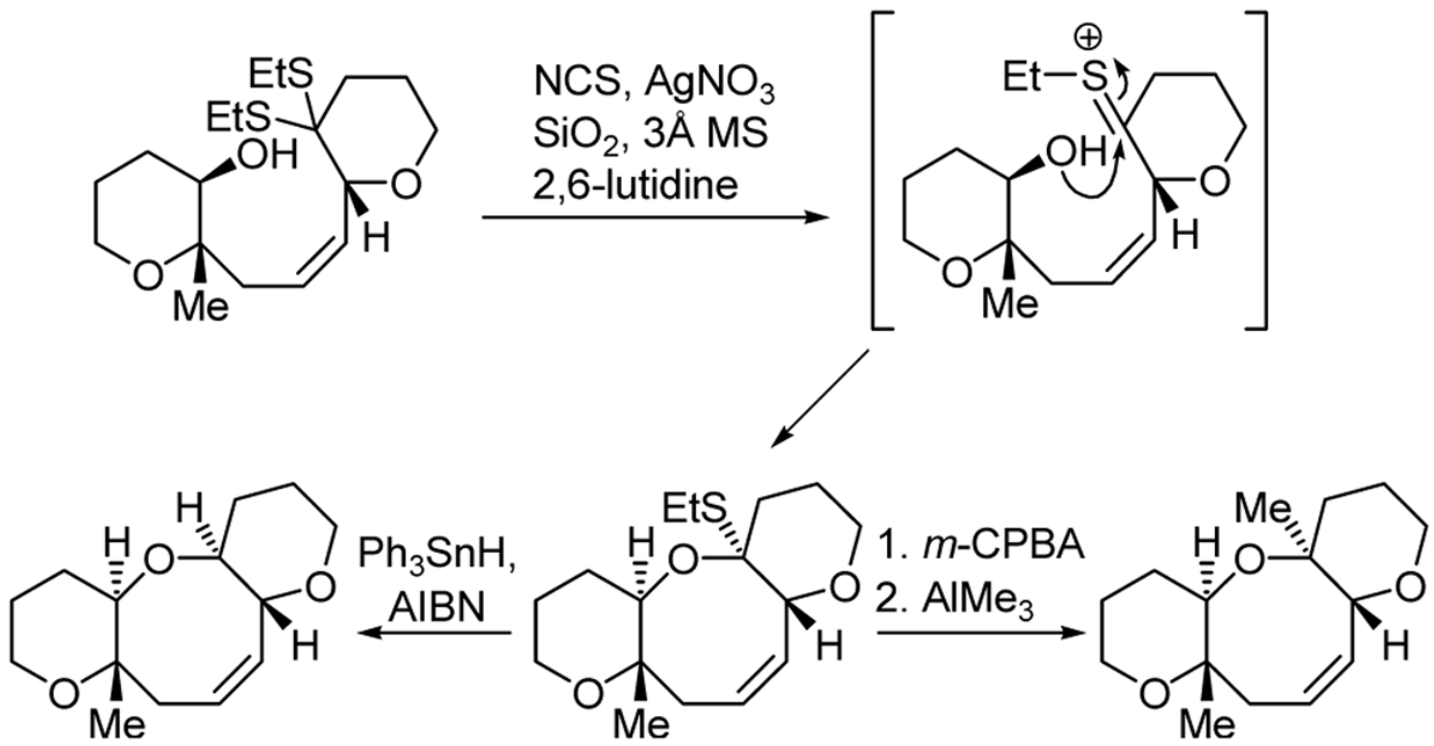

FIGURE 27.

The hydroxy dithioketal cyclization method involving mixed $O, S$-ketals for the formation of cyclic ethers (Nicolaou et al., 1986). ${ }^{79}$ 


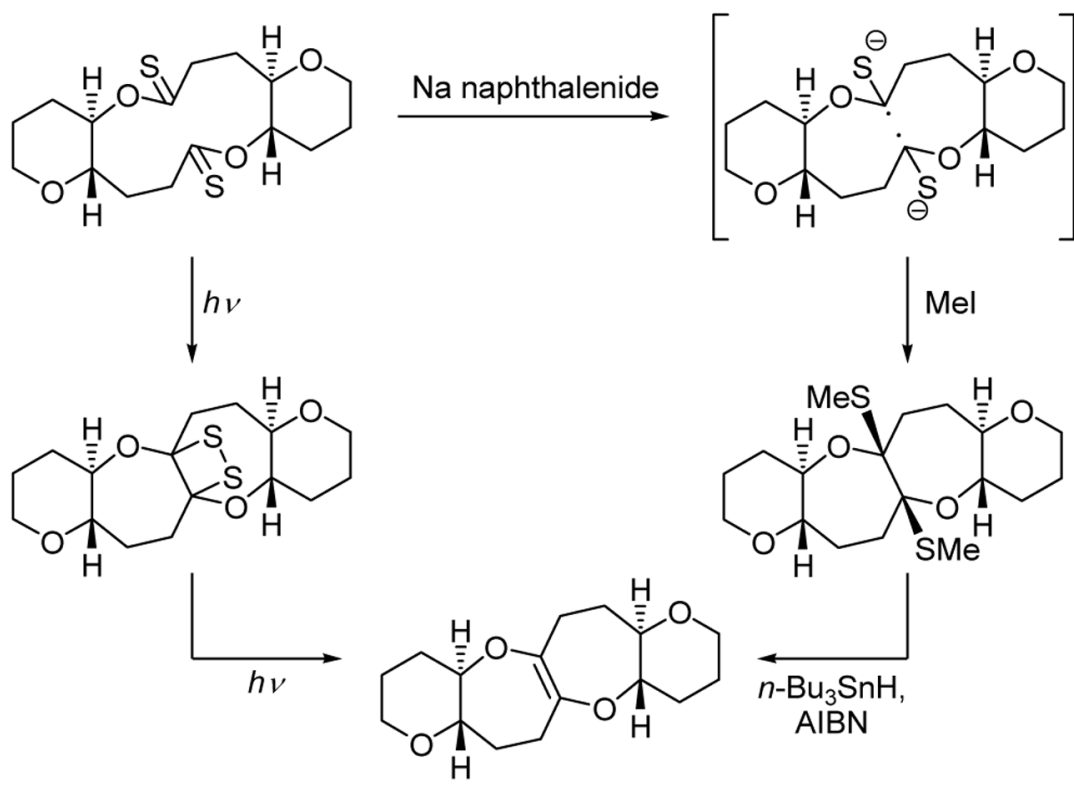

FIGURE 28.

The dithionolactone bridging method of cyclic ether formation (Nicolaou et al., 1986-1988). 80,81 

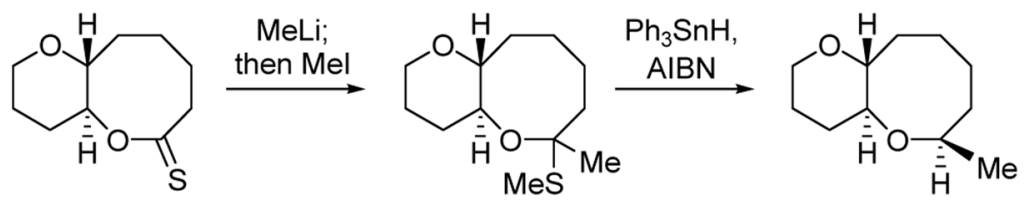

FIGURE 29.

The thionolactone nucleophilic addition/reduction method of cyclic ether formation (Nicolaou et al., 1987). ${ }^{82}$ 
(a) (Nicolaou et al., 1989)

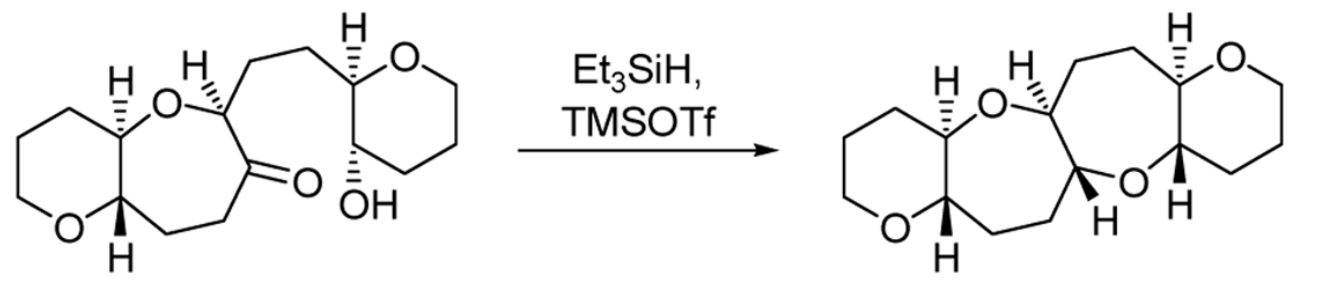

(b) (Evans et al., 2003)

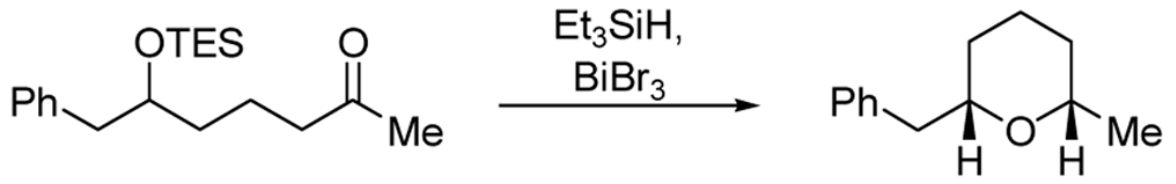

(c) (Sato and Sasaki, 2007)

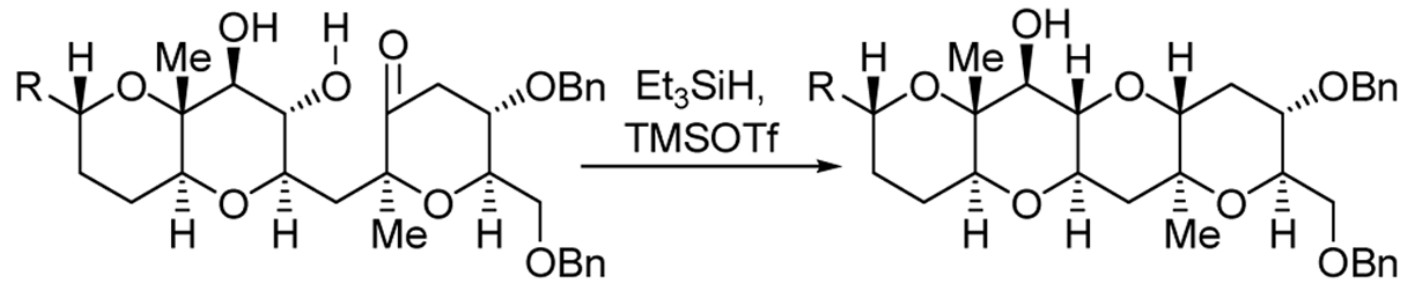

FIGURE 30.

Synthesis of cyclic ethers by hydroxy ketone reductions (Nicolaou et al., $1989 ;{ }^{81 b}$ Evans et al., 2003; ${ }^{84}$ Sato and Sasaki, $2007^{85}$ ). 

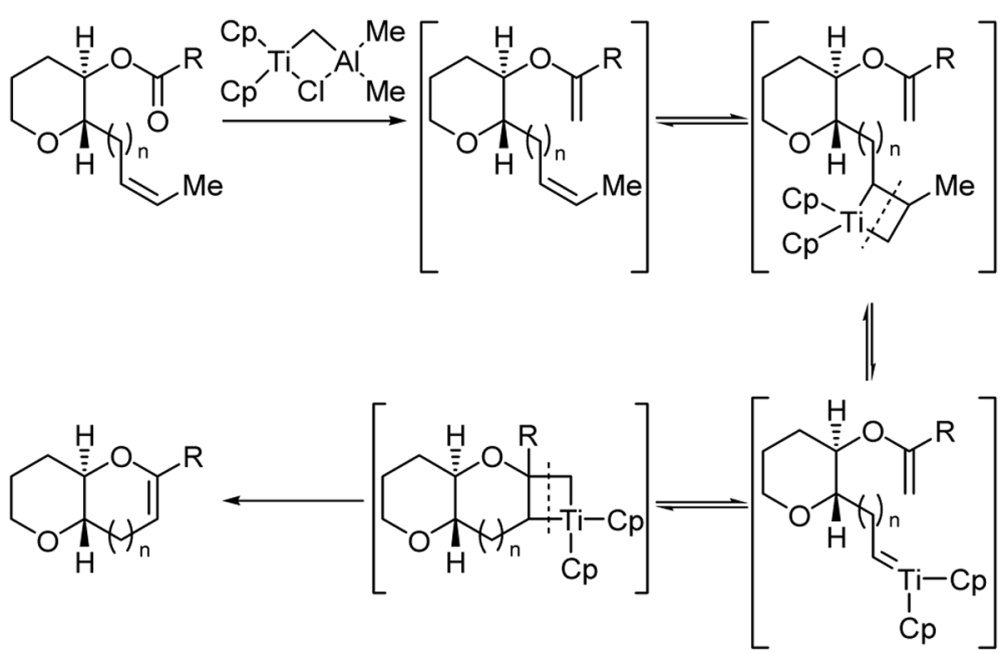

FIGURE 31.

General one pot titanium-mediated methylenation/ring closing metathesis method for the formation of cyclic polyethers (Nicolaou et al., 1996). ${ }^{87}$ 
(a)

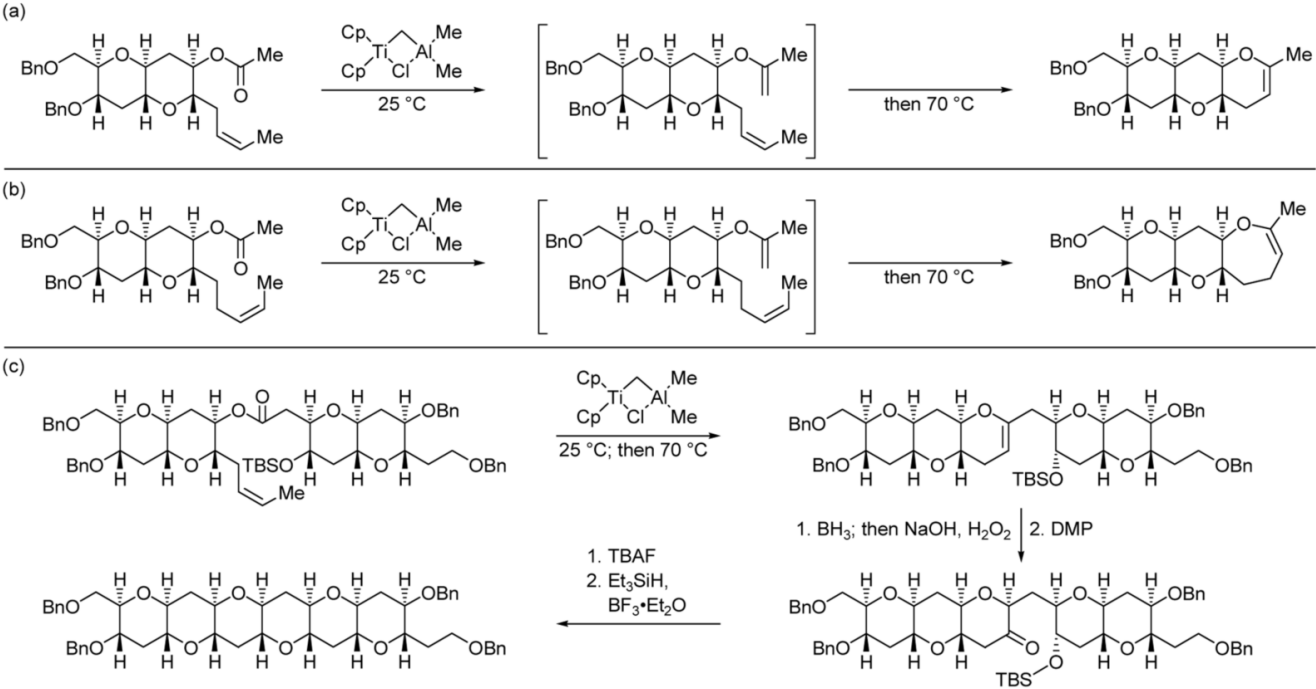

FIGURE 32.

Selected examples of the one pot titanium-mediated methylenation/ring closing metathesis construction of complex polycyclic ethers (Nicolaou et al., 1996). ${ }^{87}$ 
(a)

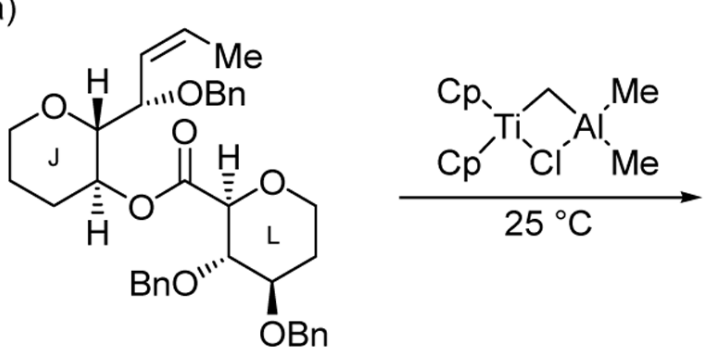

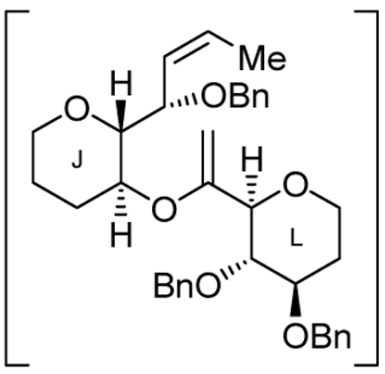

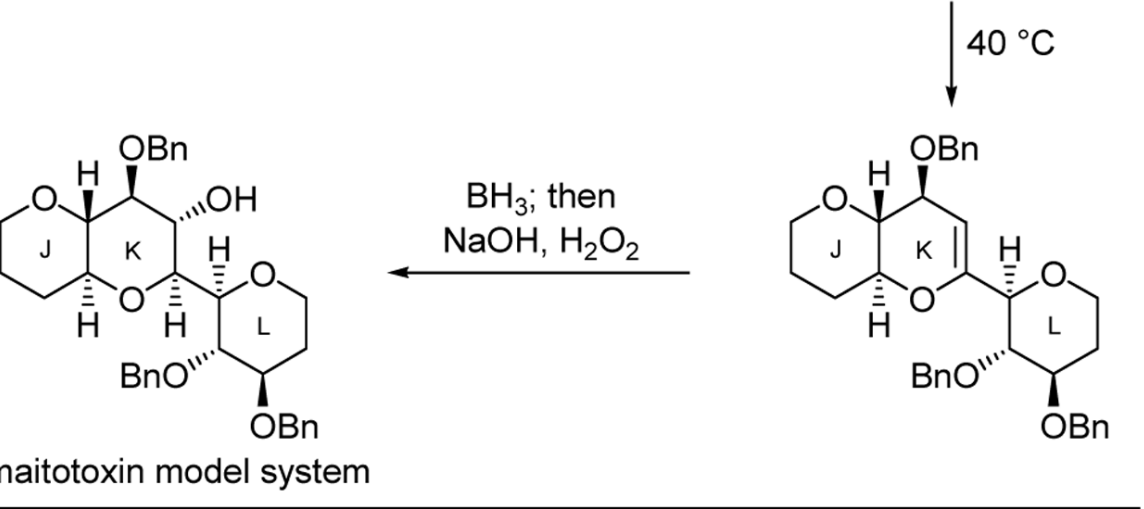

(b)
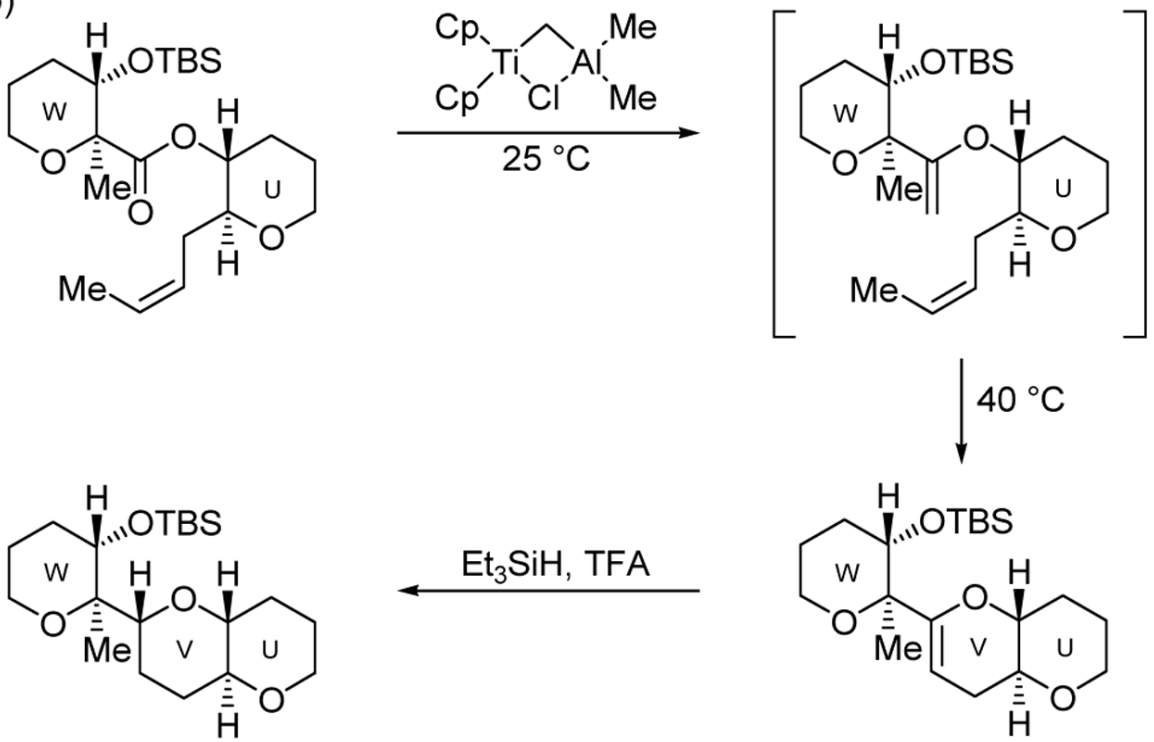

maitotoxin model system

FIGURE 33.

Convergent ester methylenation/metathesis approach to JKL and UVW maitotoxin model systems (Nicolaou et al., 1996). ${ }^{89}$ 
(a) Stille coupling (Nicolaou et al., 1997)<smiles>C=CC[C@H]1OC(=O)CC[C@@H](C)[C@@H]1ONCC</smiles>
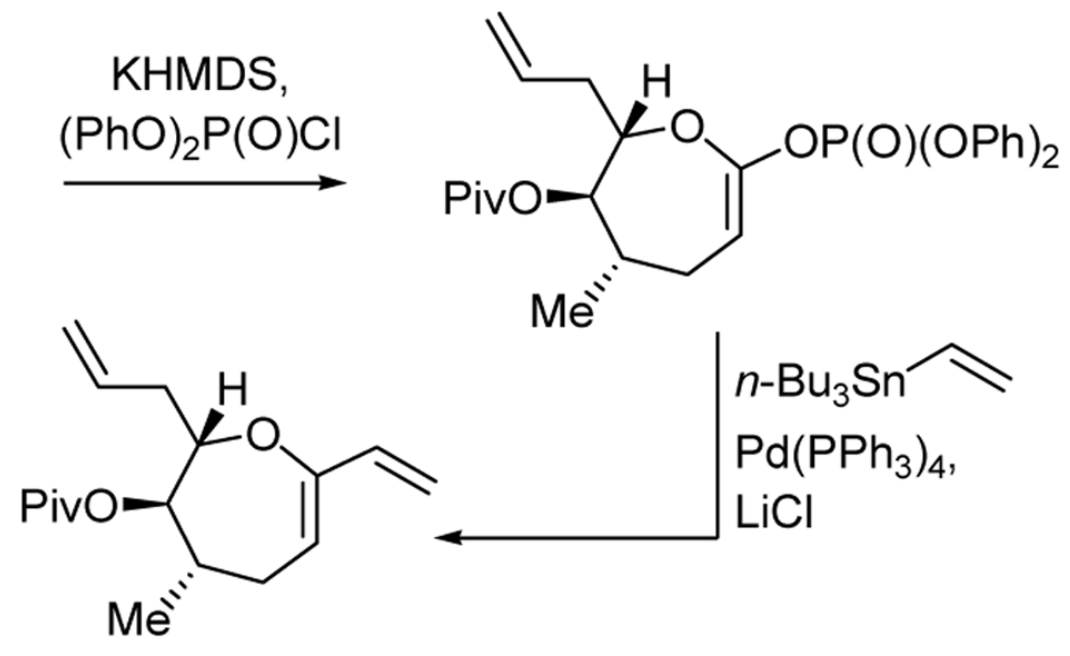

(a) B-alkyl Suzuki coupling (Sasaki et al., 1999)<smiles>C=C1O[C@H](CCOC)[C@@H](OBr)[C@H](O)[C@@H]1O[Se-]Sc1ccccc1</smiles>

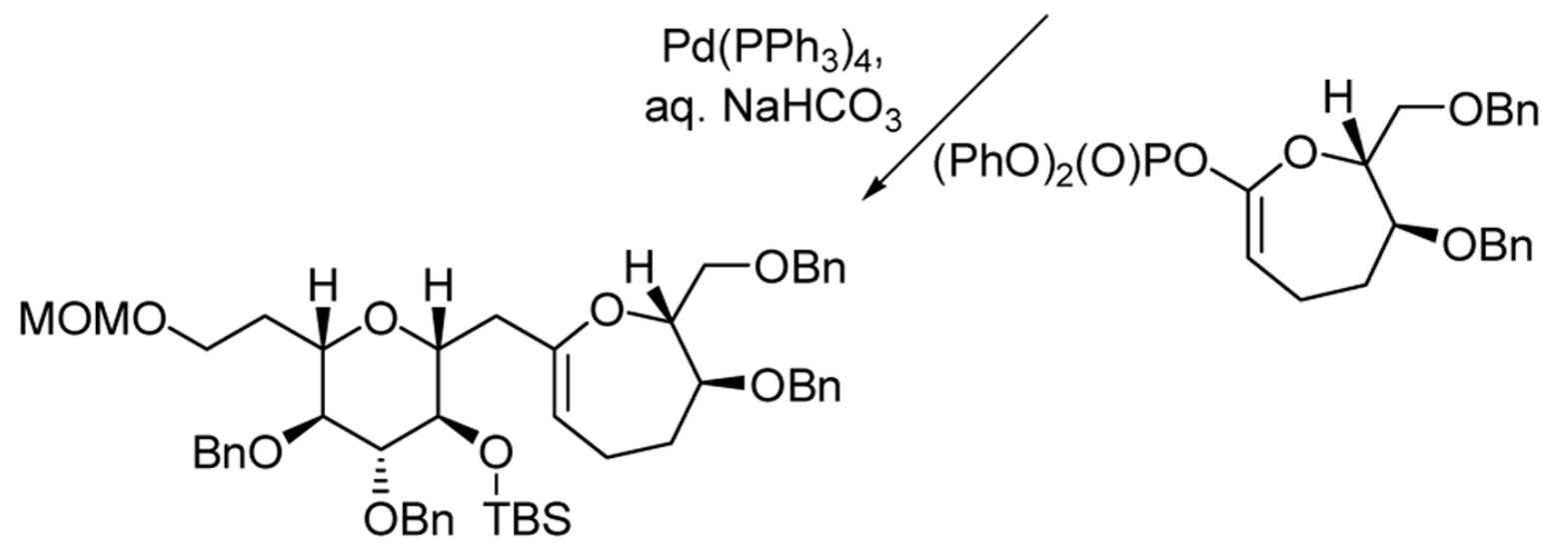

FIGURE 34.

The vinyl phosphate cross coupling method for the formation of cyclic ethers (Nicolaou et al., 1997; ${ }^{91}$ Sasaki et al., $1999^{92}$ ). 
<smiles>C=C=C=C</smiles>

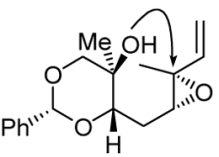

[6-endo epoxide opening]

2-deoxy-D-ribose
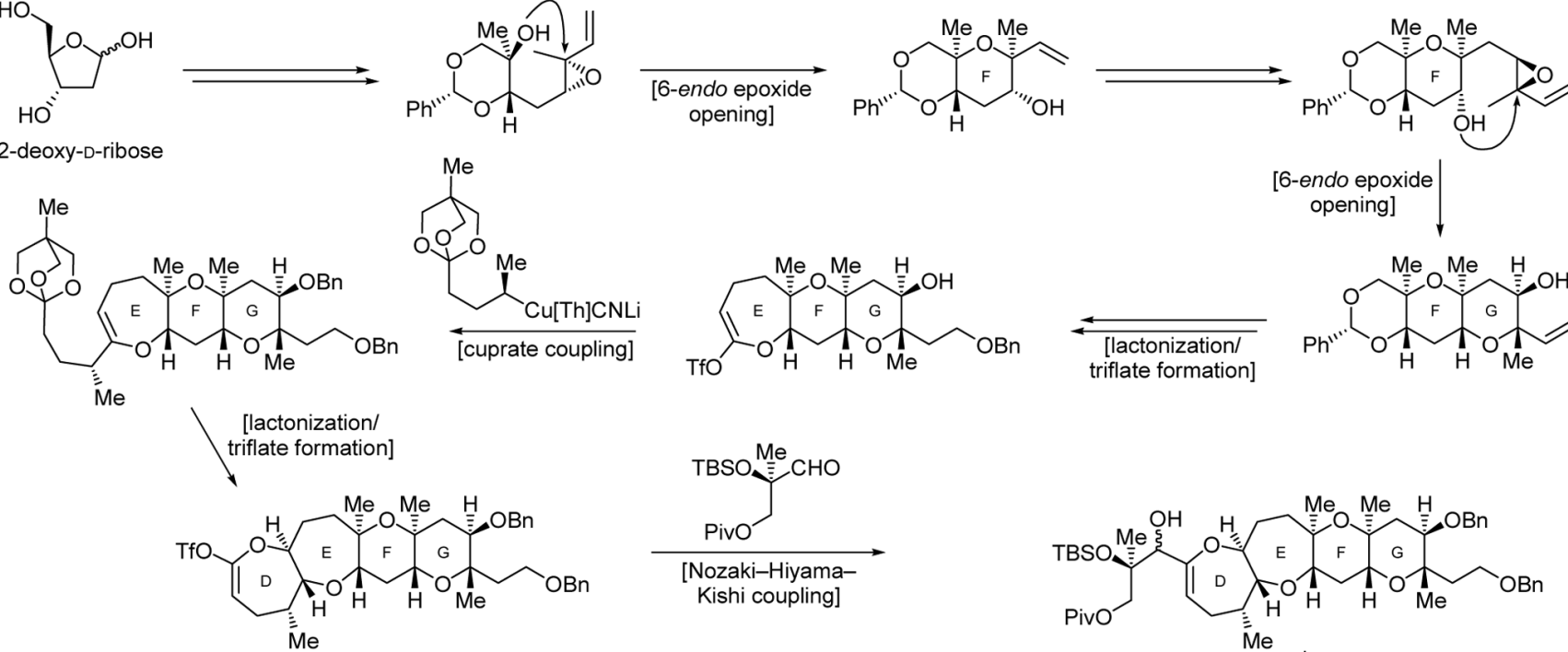

[6-endo epoxide opening]

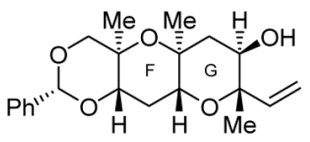
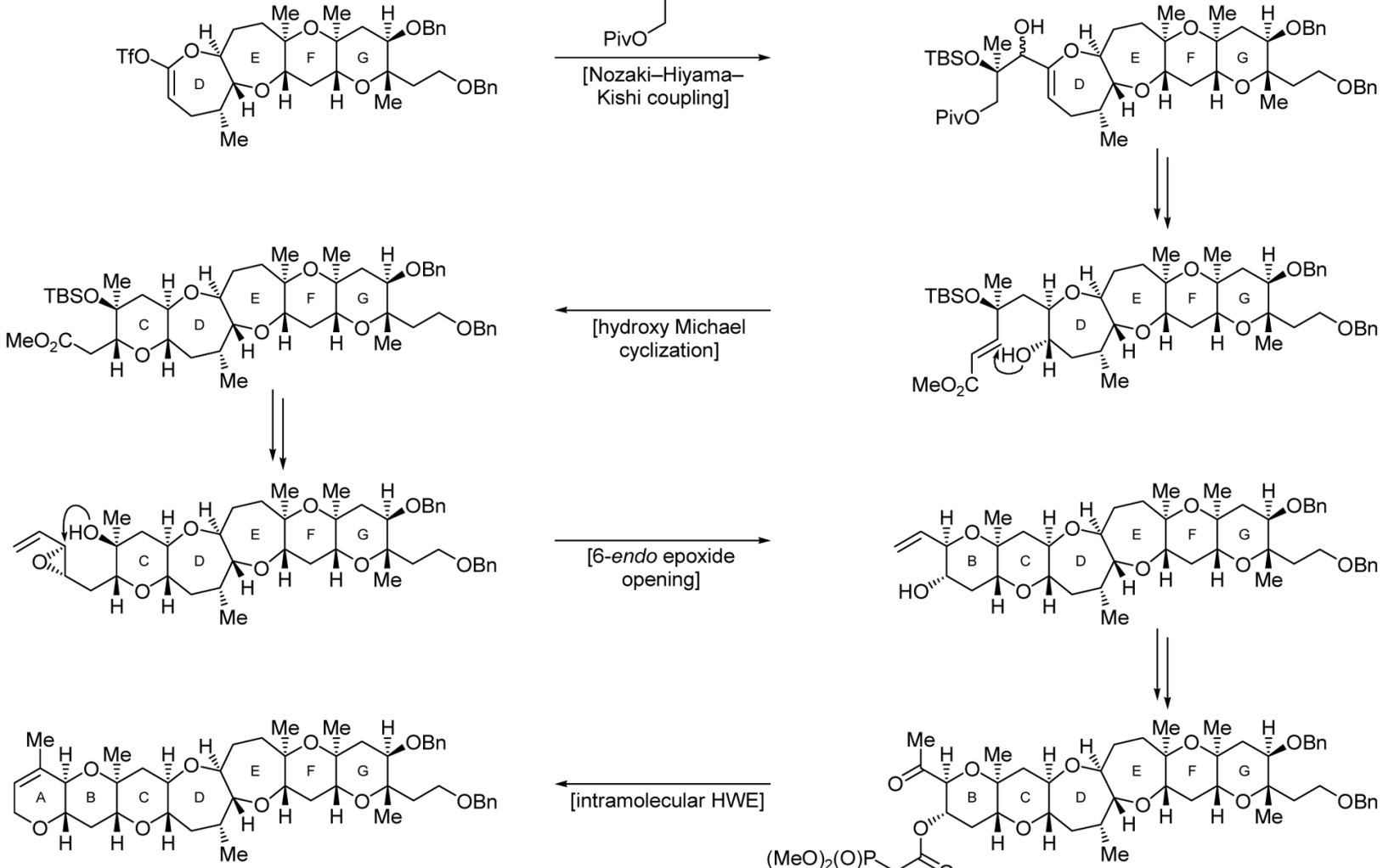

[intramolecular HWE]

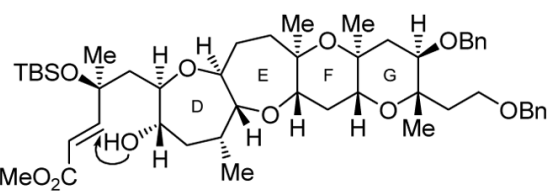

FIGURE 35.

Total synthesis of brevetoxin B. Construction of the ABCDEFG domain (Nicolaou et al., 1995). 94 
<smiles>OC[C@H]1O[C@H](O)[C@@H](O)[C@@H](O)[C@@H]1O</smiles>

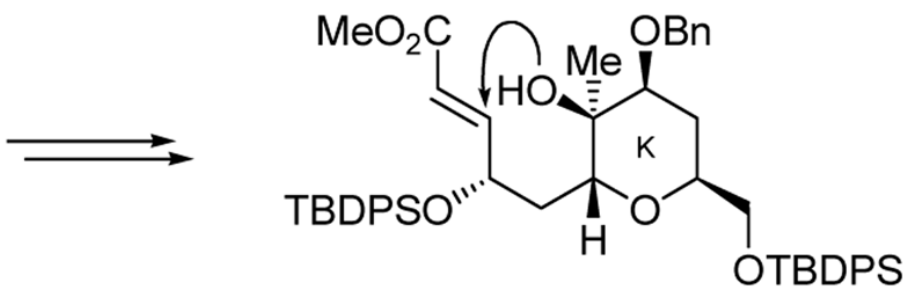

D-mannose

\section{[hydroxy Michael} cyclization]

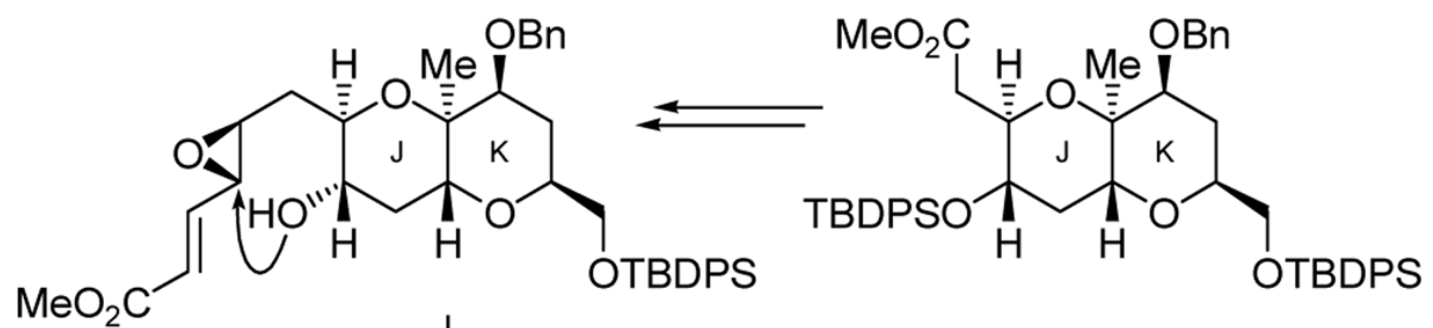
[6-endo epoxide opening]

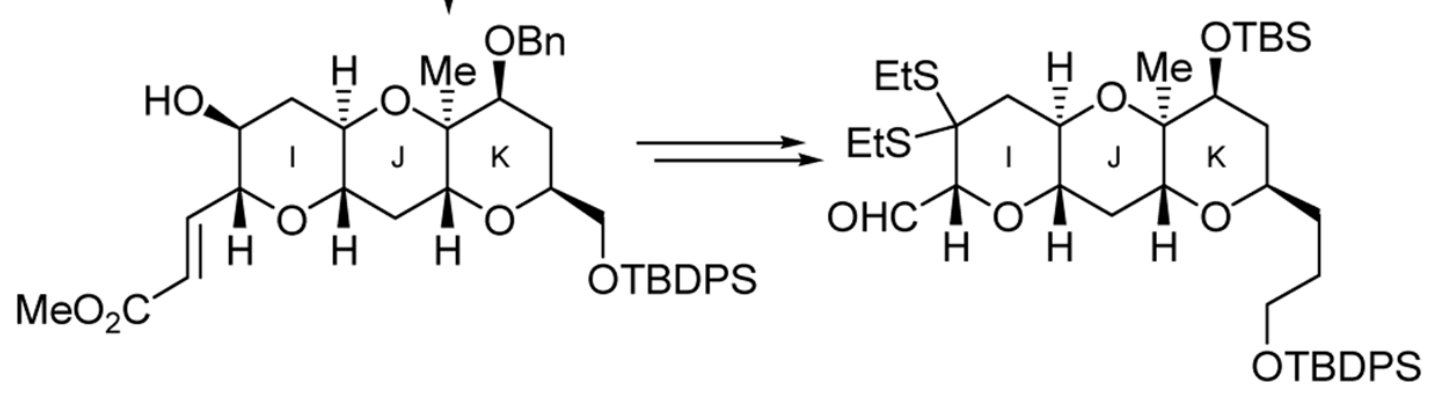

FIGURE 36.

Total synthesis of brevetoxin B. Construction of the IJK domain (Nicolaou et al., 1995). ${ }^{94}$ 

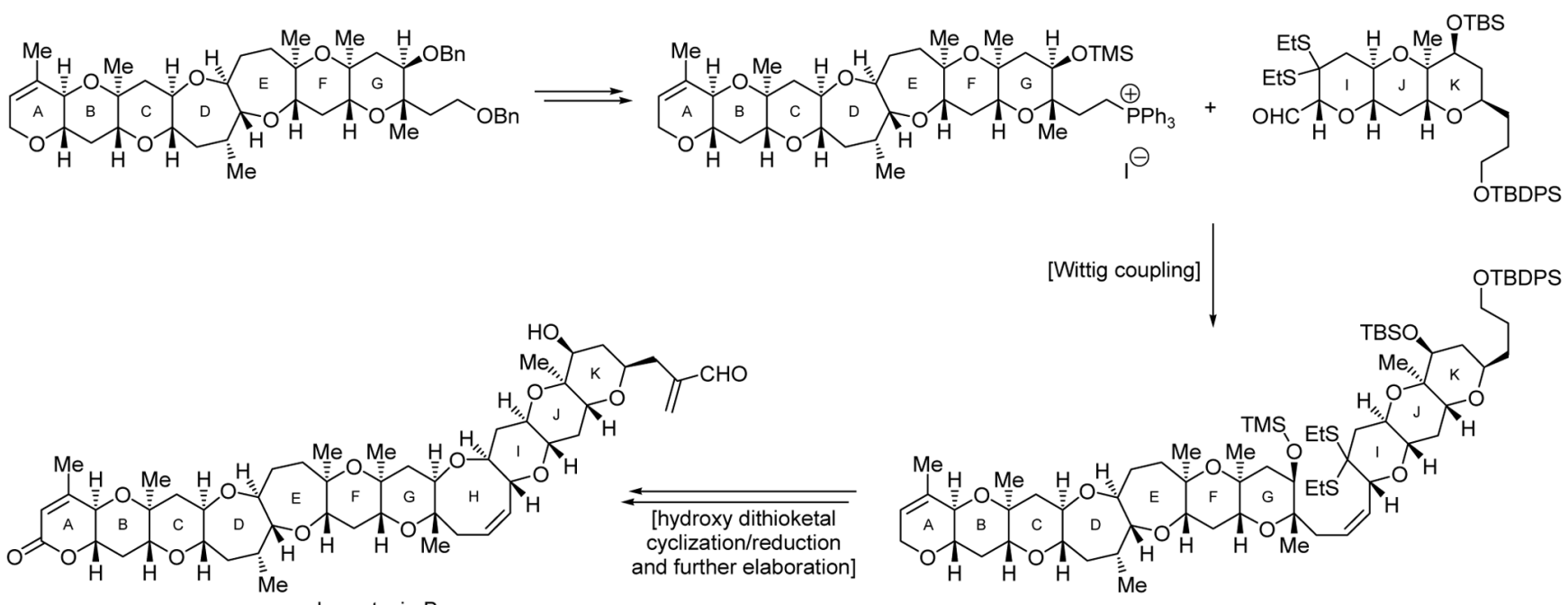

FIGURE 37.

Total synthesis of brevetoxin B. Completion of the synthesis (Nicolaou et al., 1995). ${ }^{94}$ 
<smiles>OC[C@H]1O[C@H](O)[C@@H](O)[C@H](O)[C@@H]1O</smiles>

D-mannose

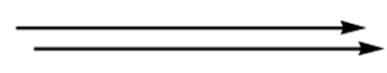

[6-endo epoxide opening]
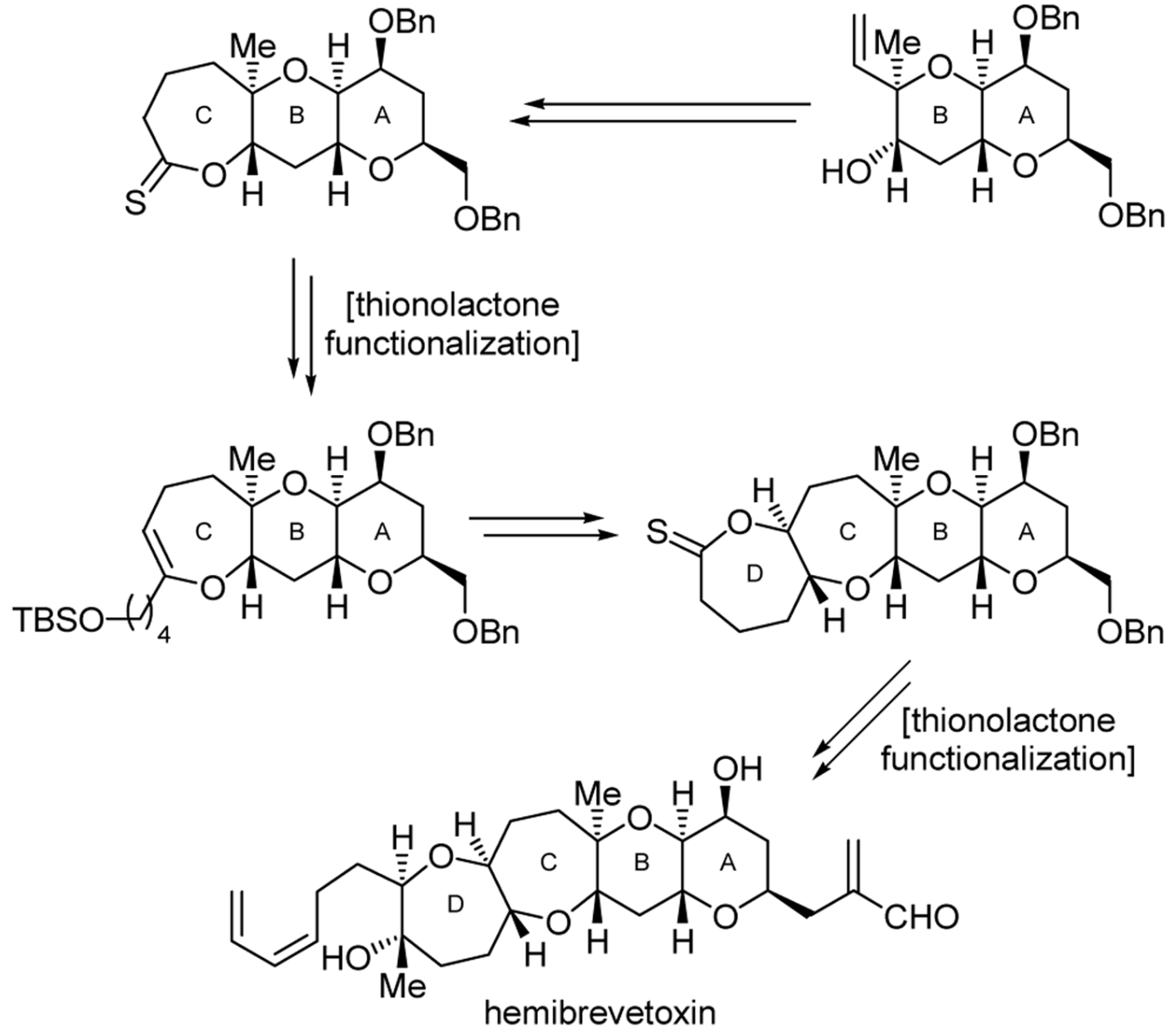

FIGURE 38.

Highlights of the total synthesis of hemibrevetoxin (Nicolaou et al., 1992). ${ }^{95}$ 


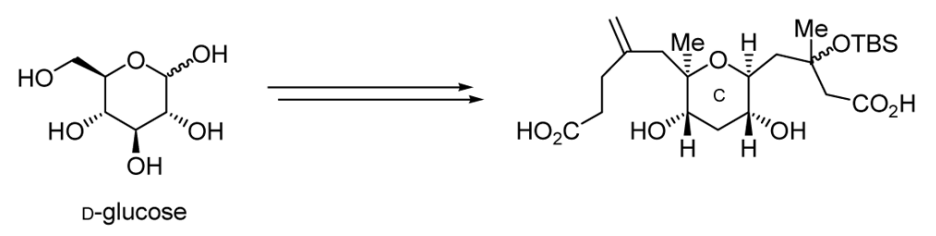

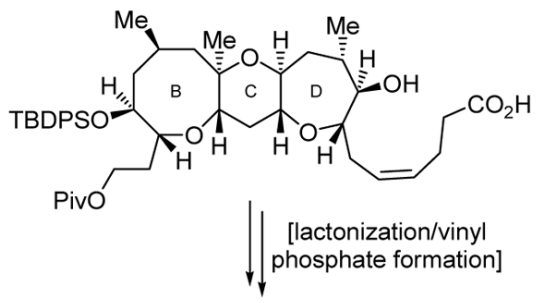

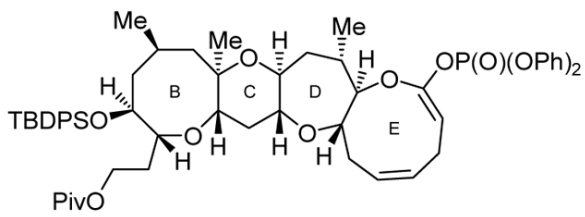

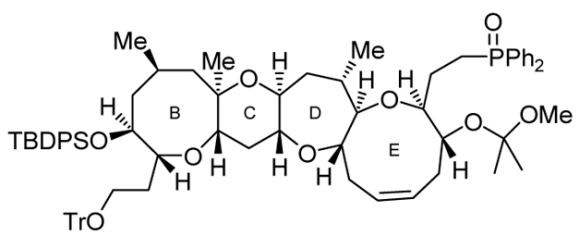

[double cuprate coupling] [vinyl phosphate/ Stille coupling]

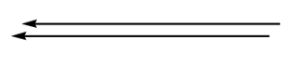

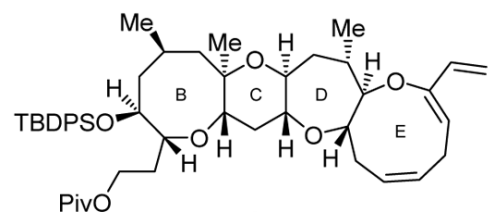

$\left[{ }^{1} \mathrm{O}_{2}[4+2]\right.$ cycloaddition]

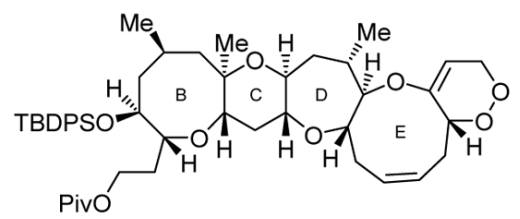

FIGURE 39.

Total synthesis of brevetoxin A. Construction of the BCDE fragment (Nicolaou et al., 1998). 96 


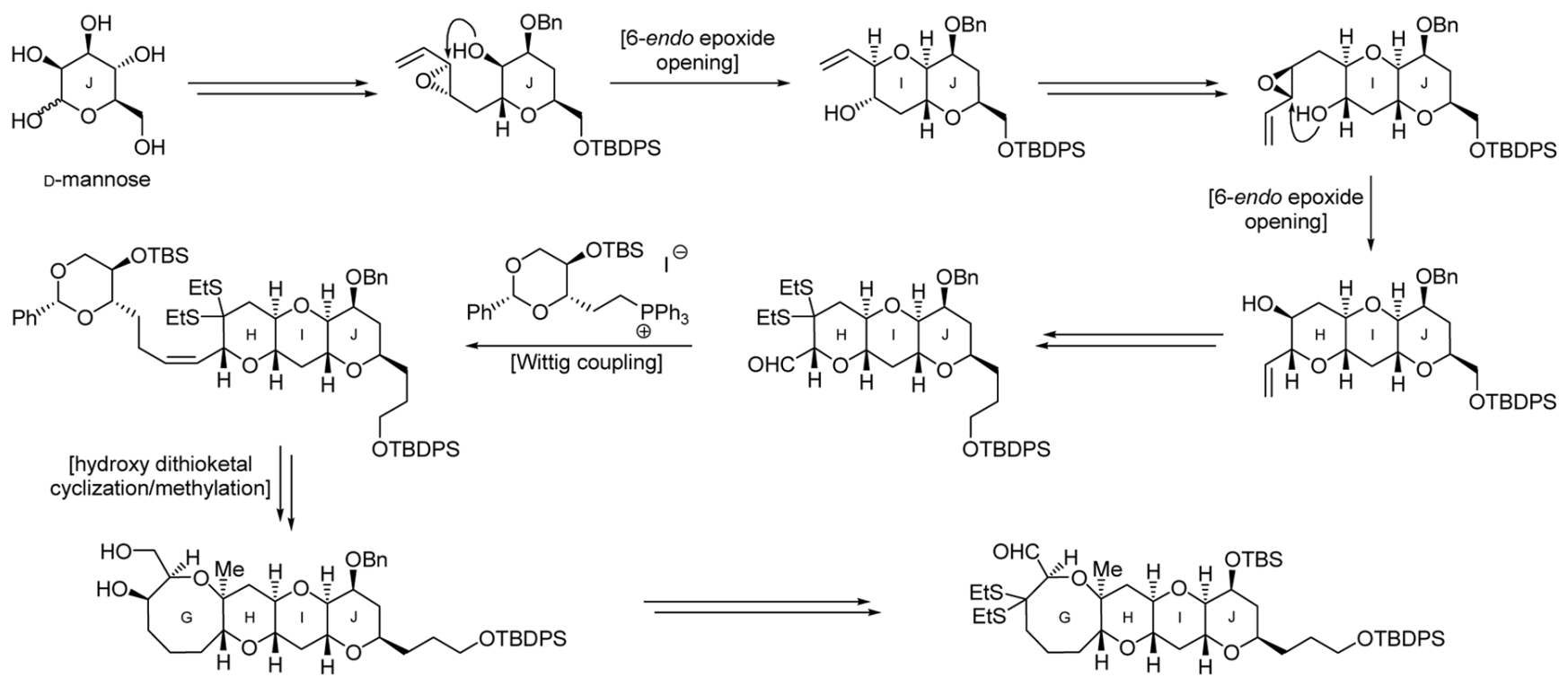

FIGURE 40.

Total synthesis of brevetoxin A. Construction of the GHIJ fragment (Nicolaou et al., 1998). 96 

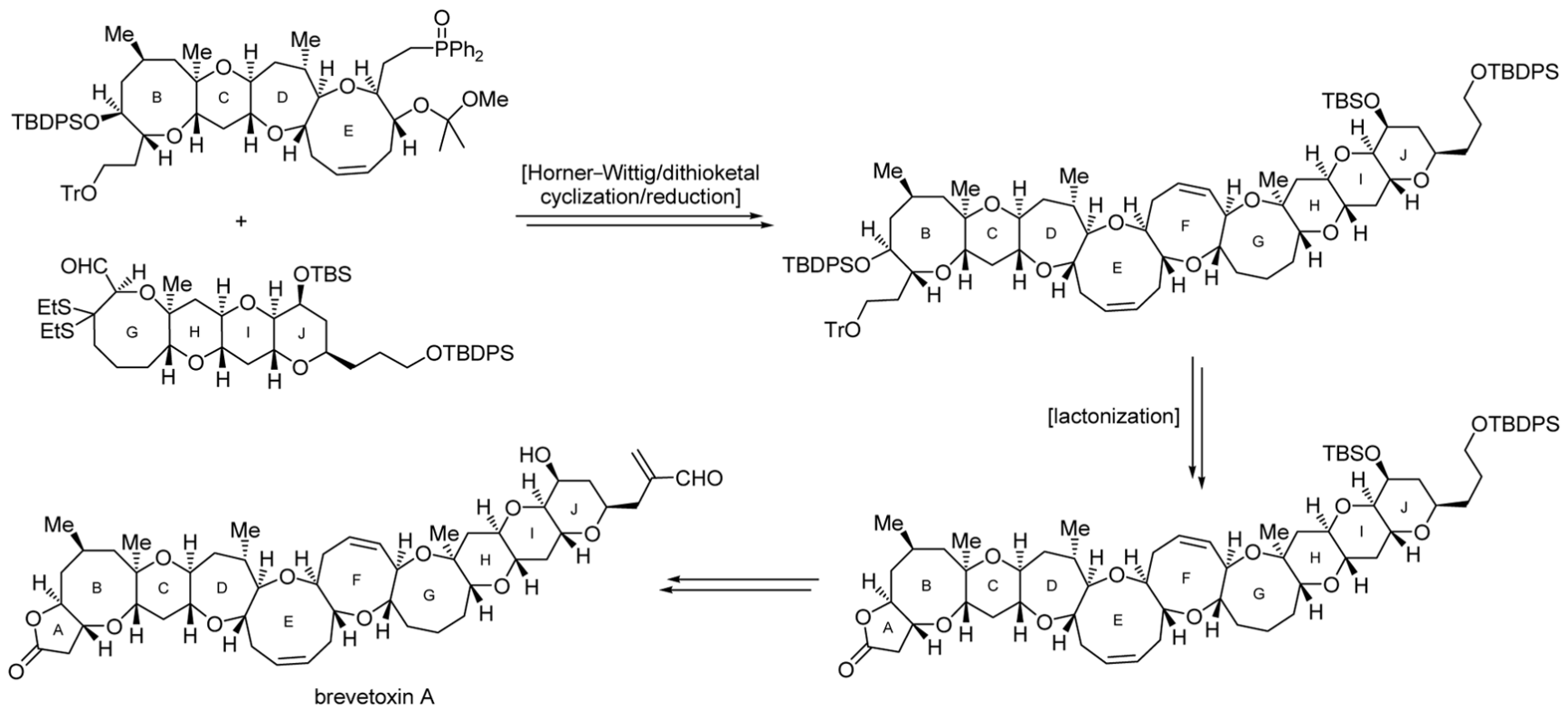

FIGURE 41.

Total synthesis of brevetoxin A. Completion of the synthesis (Nicolaou et al., 1998). 96 


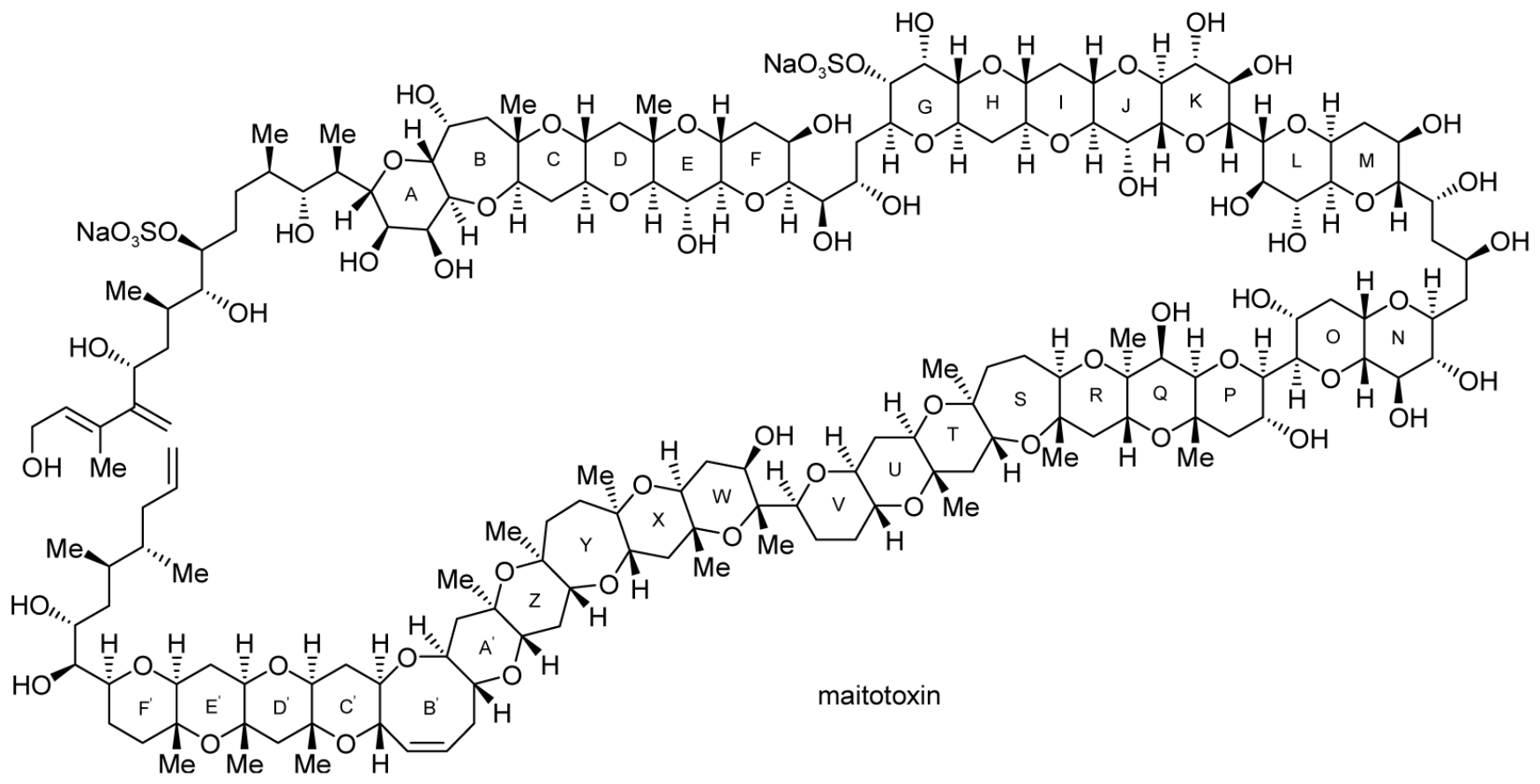

FIGURE 42.

Molecular structure of maitotoxin, the largest non-polymeric natural product isolated to date. 


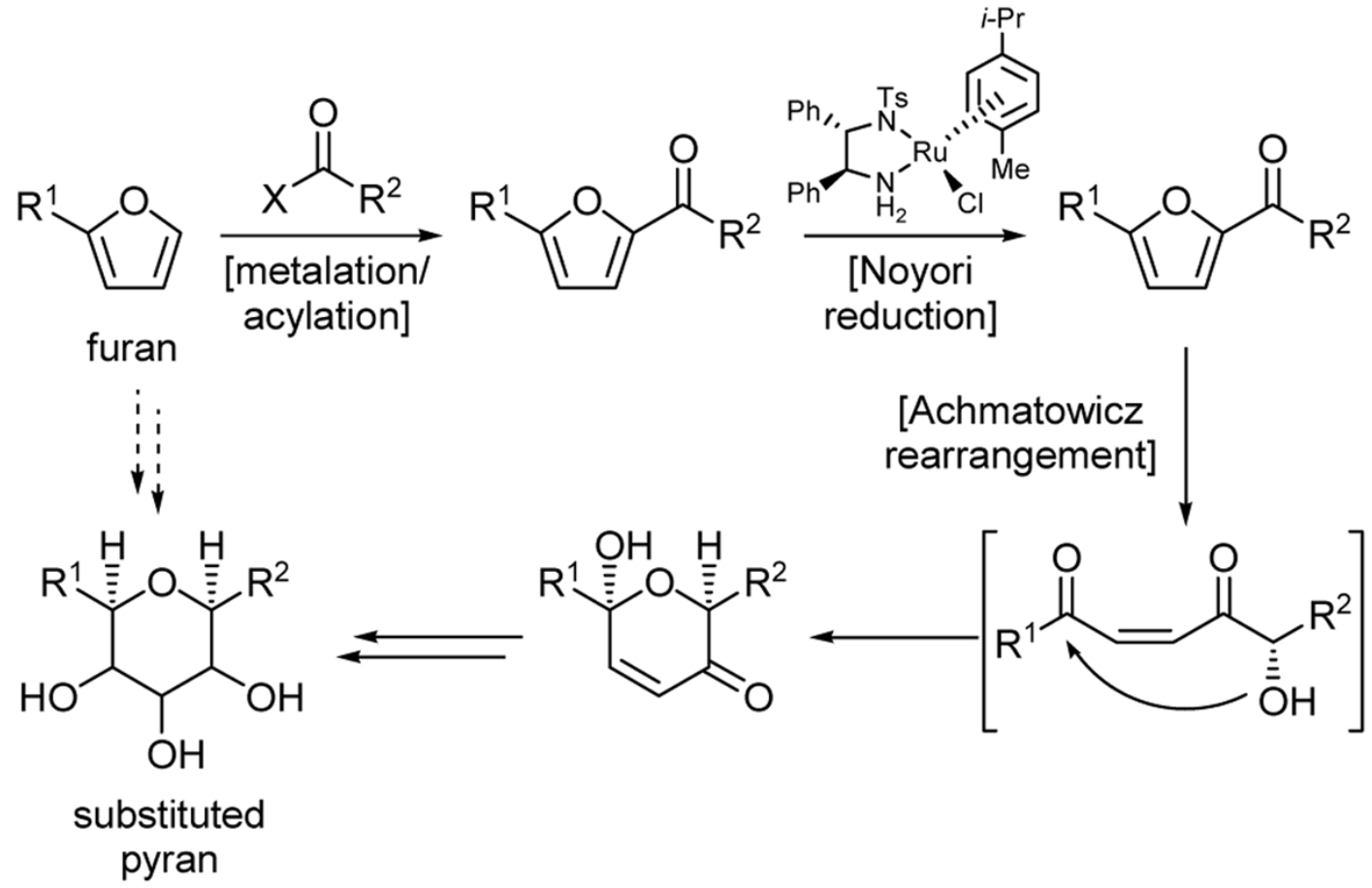

FIGURE 43.

Furan-based asymmetric synthesis of substituted pyrans through a Noyori reduction and an Achmatowicz rearrangement (Nicolaou et al., 2007). ${ }^{116}$ 


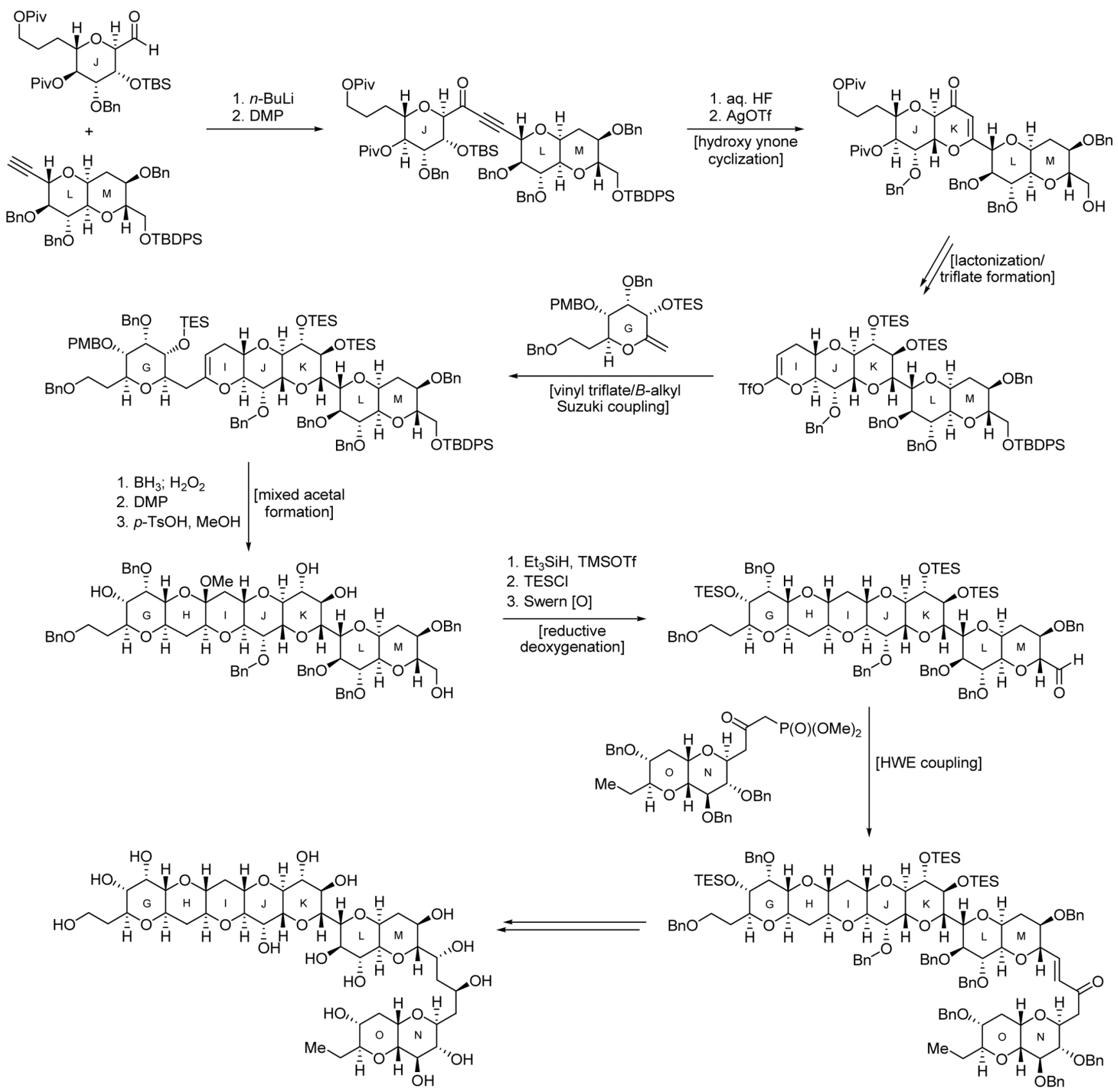

FIGURE 44.

Total synthesis of the GHIJKLMNO domain of maitotoxin (Nicolaou et al., 2008). ${ }^{118}$ 
TABLE 1

Nobel Prizes in Chemistry for organic synthesis and related areas (1901-2008)

\begin{tabular}{|c|c|c|}
\hline Year & Laureate & Citation \\
\hline 1902 & Emil Fischer & $\begin{array}{l}\text { "in recognition of the extraordinary services he has rendered by his work on } \\
\text { sugar and purine syntheses" }\end{array}$ \\
\hline 1905 & Adolf von Baeyer & $\begin{array}{l}\text { "in recognition of his services in the advancement of organic chemistry and } \\
\text { the chemical industry, through his work on organic dyes and hydroaromatic } \\
\text { compounds" }\end{array}$ \\
\hline 1910 & Otto Wallach & $\begin{array}{l}\text { "in recognition of his services to organic chemistry and the chemical industry } \\
\text { by his pioneer work in the field of alicyclic compounds" }\end{array}$ \\
\hline \multirow[t]{2}{*}{1912} & Victor Grignard & $\begin{array}{l}\text { "for the discovery of the so-called Grignard reagent, which in recent years } \\
\text { has greatly advanced the progress of organic chemistry" }\end{array}$ \\
\hline & Paul Sabatier & $\begin{array}{l}\text { "for his method of hydrogenating organic compounds in the presence of finely } \\
\text { disintegrated metals whereby the progress of organic chemistry has been } \\
\text { greatly advanced in recent years" }\end{array}$ \\
\hline 1930 & Hans Fischer & $\begin{array}{l}\text { "for his researches into the constitution of haemin and chlorophyll and } \\
\text { especially for his synthesis of haemin" }\end{array}$ \\
\hline \multirow[t]{2}{*}{1937} & Norman Haworth & "for his investigations on carbohydrates and vitamin C" \\
\hline & Paul Karrer & "for his investigations on carotenoids, flavins and vitamins $\mathrm{A}$ and $\mathrm{B}_{2}$ " \\
\hline 1938 & Richard Kuhn & "for his work on carotenoids and vitamins" \\
\hline \multirow[t]{2}{*}{1939} & Adolf Butenandt & "for his work on sex hormones" \\
\hline & Leopold Ruzicka & "for his work on polymethylenes and higher terpenes" \\
\hline 1947 & Sir Robert Robinson & $\begin{array}{l}\text { "for his investigations on plant products of biological importance, especially } \\
\text { the alkaloids" }\end{array}$ \\
\hline 1950 & Otto Diels and Kurt Alder & "for their discovery and development of the diene synthesis" \\
\hline 1955 & Vincent du Vigneaud & $\begin{array}{l}\text { "for his work on biochemically important sulphur compounds, especially for } \\
\text { the first synthesis of a polypeptide hormone" }\end{array}$ \\
\hline 1957 & Lord (Alexander R.) Todd & "for his work on nucleotides and nucleotide co-enzymes" \\
\hline 1963 & Karl Ziegler and Giulio Natta & $\begin{array}{l}\text { "for their discoveries in the field of the chemistry and technology of high } \\
\text { polymers" }\end{array}$ \\
\hline 1964 & Dorothy Crowfoot Hodgkin & $\begin{array}{l}\text { "for her determinations by X-ray techniques of the structures of important } \\
\text { biochemical substances" }\end{array}$ \\
\hline 1965 & Robert B. Woodward & "for his outstanding achievements in the art of organic synthesis" \\
\hline 1969 & Derek H. R. Barton and Odd Hassel & $\begin{array}{l}\text { "for their contributions to the development of the concept of conformation } \\
\text { and its application in chemistry" }\end{array}$ \\
\hline 1973 & Ernst Otto Fischer and Geoffrey Wilkinson & $\begin{array}{l}\text { "for their pioneering work, performed independently, on the chemistry of the } \\
\text { organometallic, so called sandwich compounds" }\end{array}$ \\
\hline \multirow[t]{2}{*}{1975} & John Cornforth & "for his work on the stereochemistry of enzyme-catalyzed reactions" \\
\hline & Vladimir Prelog & "for his research into the stereochemistry of organic molecules and reactions" \\
\hline 1979 & Herbert C. Brown and Georg Wittig & $\begin{array}{l}\text { "for their development of the use of boron- and phosphorus-containing } \\
\text { compounds, respectively, into important reagents in organic synthesis" }\end{array}$ \\
\hline 1981 & Kenichi Fukui and Roald Hoffmann & $\begin{array}{l}\text { "for their theories, developed independently, concerning the course of } \\
\text { chemical reactions" }\end{array}$ \\
\hline 1984 & R. Bruce Merrifield & $\begin{array}{l}\text { "for his development of methodology for chemical synthesis on a solid } \\
\text { matrix" }\end{array}$ \\
\hline 1987 & $\begin{array}{l}\text { Donald J. Cram, Jean-Marie Lehn and } \\
\text { Charles J. Pedersen }\end{array}$ & $\begin{array}{l}\text { "for their development and use of molecules with structure-specific } \\
\text { interactions of high selectivity" }\end{array}$ \\
\hline 1990 & Elias J. Corey & "for his development of the theory and methodology of organic synthesis" \\
\hline 1994 & George A. Olah & "for his contribution to carbocation chemistry" \\
\hline 1996 & $\begin{array}{l}\text { Robert F. Curl, Jr., Harold W. Kroto and } \\
\text { Richard E. Smalley }\end{array}$ & "for their discovery of fullerenes" \\
\hline
\end{tabular}




$\begin{array}{lll}\text { Year } & \text { Laureate } & \text { Citation }\end{array}$

$2000 \quad$ Alan J. Heeger, Alan G. MacDiarmid, and "for the discovery and development of conductive polymers"

$2001 \quad$ William S. Knowles and Ryoji Noyori "for their work on chirally catalyzed hydrogenation reactions"

K. Barry Sharpless "for his work on chirally catalyzed oxidation reactions"

2005 Yves Chauvin, Robert H. Grubbs and Richard R. Schrock

"for the development of the metathesis method in organic synthesis" 